Portland State University

PDXScholar

11-19-1992

\title{
How Gothic Influences and Eidetic Imagery in Eight Color Plates and Key Poems by William Blake Figuratively Unite Body and Soul by Dramatizing the Visionary Imagination
}

Honor Penelope Vallor

Portland State University

Follow this and additional works at: https://pdxscholar.library.pdx.edu/open_access_etds

Part of the English Language and Literature Commons

Let us know how access to this document benefits you.

\section{Recommended Citation}

Vallor, Honor Penelope, "How Gothic Influences and Eidetic Imagery in Eight Color Plates and Key Poems by William Blake Figuratively Unite Body and Soul by Dramatizing the Visionary Imagination" (1992). Dissertations and Theses. Paper 4659.

https://doi.org/10.15760/etd.6543

This Thesis is brought to you for free and open access. It has been accepted for inclusion in Dissertations and Theses by an authorized administrator of PDXScholar. Please contact us if we can make this document more accessible: pdxscholar@pdx.edu. 
AN ABSTRaCt of THE THESIS OF Honor Penelope Vallor for the Master of Arts in English presented November 19, 1992.

Title: How Gothic Influences and Eidetic Imagery in Eight Color Plates and Key Poems by William Blake Figuratively Unite Body and Soul by Dramatizing the Visionary Imagination.

APPROVED BY THE MEMBERS OF THE THESIS COMMITTEE:

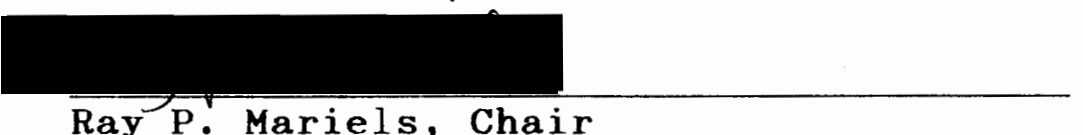
Ray P. Mariels, Chair
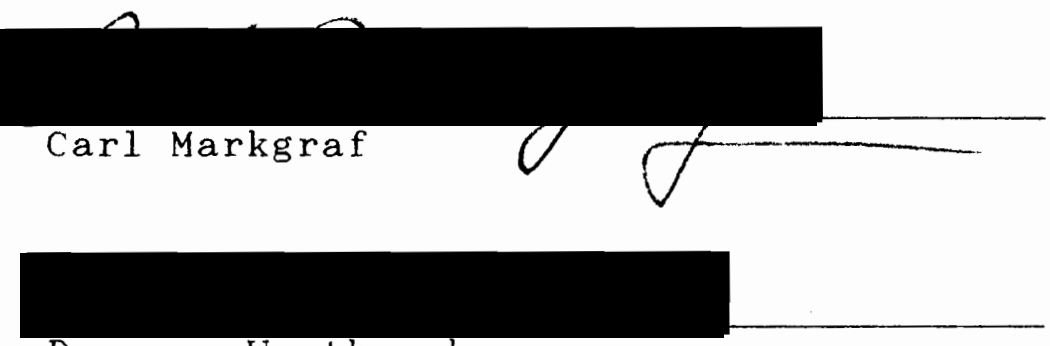

Deeanne Westbrook

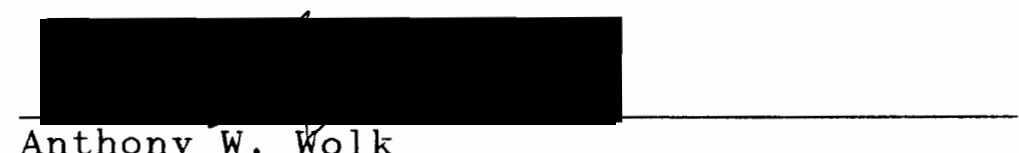

Anthony W. Wolk

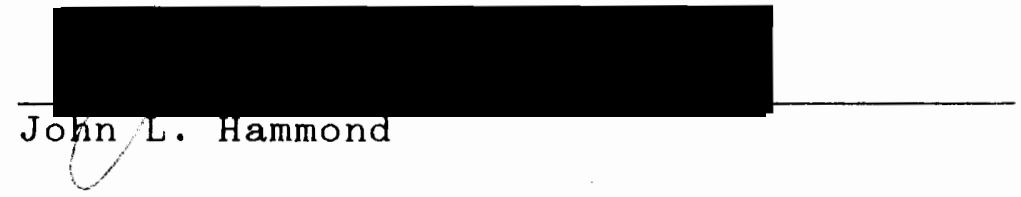

A study of Gothic influences and eidetic imagery evident in eight Blake color plates to demonstrate that, 
when interpreted together with key Blake poems, unity of body and soul can be accomplished by means of the visionary imagination. 
HOW GOTHIC INFLUENCES AND EIDETIC IMAGERY IN EIGHT COLOR PLATES AND KEY POEMS BY WILLIAM BLAKE FIGURATIVELY UNITE BODY AND SOUL BY DRAMATIZING THE VISIONARY IMAGINATION

by

HONOR PENELOPE VALLOR

A thesis submitted in partial fulfillment of the requirement for the degree of

\author{
MASTER OF ARTS \\ in \\ ENGLISH
}

Portland State University

1993 
TO THE OFFICE OF GRADUATE STUDIES:

The members of the Committee approve the thesis of Honor Penelope Vallor presented November 19, 1992.

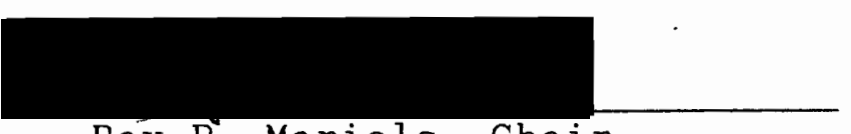

Ray P. Mariels, Chair

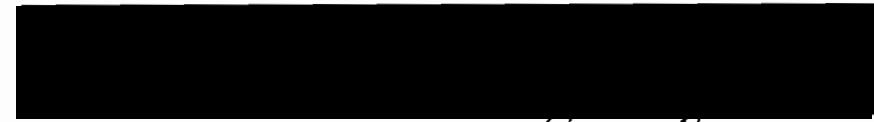

Carl Markgraf

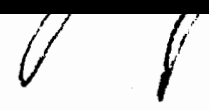

Deeanne Westbrook

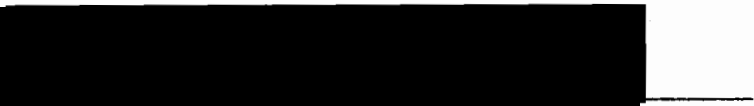

Anthony $w$. Wolk

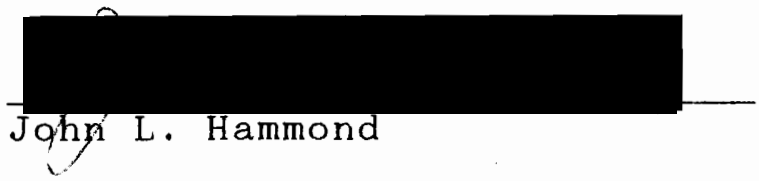

APPROVED :

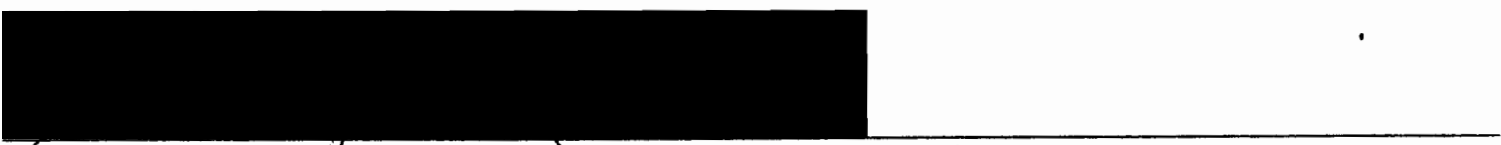

Shelley C. Regce, Chair, Department of English

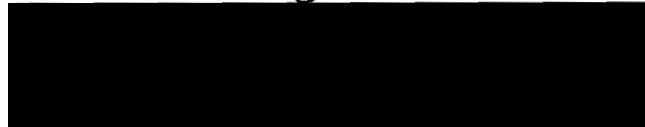

Roy W. Koch, Vice Provost for Graduate Studies and Research 


\section{DEDICATION}

To the visionary eye, which perceives how Anubis camels her backl synchronously with that beyond the shadow screen.? To the full opening of the "doors of perception" ${ }^{\hat{j}}$ through the marriage of image and word. To one "Who Present, Past, \& Future sees"4 from the central still point of Vision.

--- For Adam and Mark- - -

i Christopher Smart, "Jubilate Agno": "For I will consider my cat Jeoffrey"; "For he camels his back to bear the first notion of business" (1 ines 697, 756). Smart perceives his cat to be a diminutive form of the larger felidae: "For the Cherub Cat is a term of the Angel Tyger," The Norton Anthology of Poetry, 3rd. ed. Alexander $h$. Allison et al., eds. (New York: W.W. Norton \& Company, Inc., 1983) 470, Iine 725 .

2 The Wayang Kulit shadow puppet theater of Indonesia in which flat, leather puppets are manipulated by the Dhalang, the puppeteer, behind a semi-transparent, back-lit screen to the accompaniment of the Gamelin orchestra.

3 William Blake, "The Marriage of Heaven and Hell," Blake's Poetry and Designs, Mary Lynn Johnson and John E. Grant, eds. (New York: W.W. Norton \& Company, Inc., 1979) 93, Plate 14, 1 ine 12 .

4 William Blake, "Introduction," "Songs of Experience" Blake's Poetry and Designs, Mary Lynn Johnson and John $E$. Grant, eds. (New York: W.W. Norton \& Company, Inc., 1979) 1-2. 
TABLE OF CONTENTS

\section{PAGE}

LIST OF FIGURES......................... iv

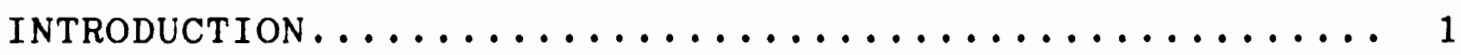

THE PLATES.............................. 18

Gothic Influences, Zoas, and Eidetic Imagery. 18

The Ghost of a Flea............. 38

Blake's Iconography of Visionary Imagination. 71

Eyes as Symbols............... 74

Vortices as Symbols............. 83

Imagination In Opposition to

Mechanistic Physics............. 98

Convolution Motifs as Symbols for

Levels of Consciousness........... 104

Human Form as Icon: "The Divine Image"..... 111

Adam Naming the Beasts.......... 119

Christ Blessing.............. 139

Glad Day or The Dance of Albion.... 143

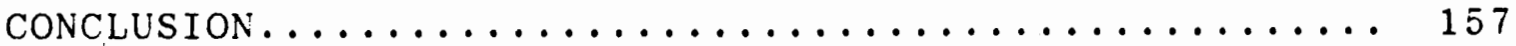

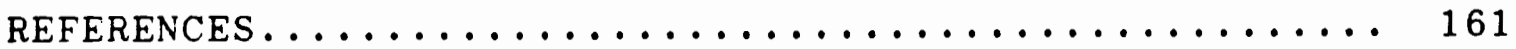




\section{LIST OF FIGURES}

FIGURE

PAGE

1. Ekekiel's wheels.................... 10

2. Adam Naming the Beasts................ 11

3. Christ Blessing................... 15

4. Glad Day or The Dance of Albion........... 17

5. God Blessing the Seventh Dav............ 36

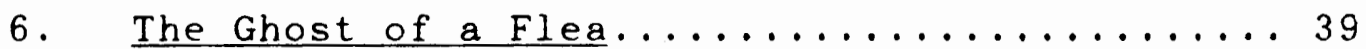

7. Satan in His Original Glory.............44

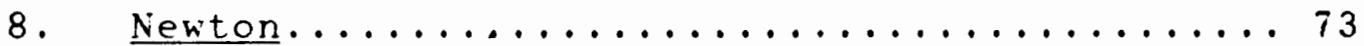




\section{INTRODUCTION}

William Blake's paradoxical poetic and visual imagery is composed of a series of unsettling dichotomies: awe and satire, delicacy and vigor, stasis and turbulence, the quotidian and the abstruse. The oxymoronic clash dramatizes their complementary nature, since one state is known by its opposite: "For Mercy has a human heart" in Innocence, yet "Cruelty has a Human Heart" in Experience. 5 Contrariness manifests when nature is free: "One Law for the Lion \& Ox is Oppression." 6 Opposing states seem disharmonious from the mundane perspective and paradox arises, but creative tension is necessary to organic vitality; as body has a reciprocal relationship with soul, image and word are complementary. Blake figuratively reconciles disunity between body and soul through his integrated visual image and poetic word to demonstrate that imagination transforms human nature "as it

5 William Blake, "The Divine Image," Songs of Innocence and "A Divine Image" in Songs of Experience, Blake's Poetry and Designs, Mary Lynn Johnson and John E. Grant, eds. (New York: W.W. Norton \& Company, Inc. 1979) $30,60$.

6 Different natures require different methods or approaches. William Blake, "A Memorable Fancy," The Marriage of Heaven and Hell, Blake's Poetry and Designs, Mary Lynn Johnson and John E. Grant, eds. (W.W. Norton \& Company, Inc., 1979) 101 . 
awakens to its visionary capacity."?

While much Blake criticism has considered the relationship between his visual art and his poetic word, especially in the illuminated manuscripts, it has neglected to examine the effects of Gothic iconic influences combined with personal eidetic imagery on his visual art and poesy as analogs to body and soul. I offer new insights by demonstrating that Blake adapts Gothic iconography and eidetic imagery to dramatize the transformative power of visionary imagination in his complementary visual image and poetic word as figurative body and soul. Although many Blake plates would serve to support this claim, the eight color plates chosen most lucidly demonstrate my thesis: that the study of eidetic imagery and Gothic influences reveals insights about how the visionary imagination works, a revelation not previously shown in the scholarship.

Blake dramatizes imagination with eyes and vortices that are symbolic to indicate that perception alters experience and to show how visionary imagination reconciles dichotomy between body and soul. Analogous to body (Image) and spirit (Word), ice and steam are both water; in one the structure is more apparent, while the other is known by its effects; the transforming principle is the flame of

7 Commentary to "All Religions are One and There Is No Natural Religion," William Blake, Blake's Poetry and Designs, Mary Lynn Johnson and John E. Grant, eds. (New York: W.W. Norton \& Company, 1979) 12. 
visionary imagination. To demonstate this complement of figurative body and spirit, Blake appropriates the paradigm of Gothic iconography in which the structure of the cathedral or religious icon expresses the implied presence of spirit. Blake also incorporates idiosyncratic elements derivative of Gothic's irregularities and the lively individuality of its organic decoration expressive of spirit. Medieval iconic images intend to be interpreted according to the traditional four levels of biblical exegesis. Customarily, the iconic image is distilled in the religious icon, which was originally a

devotional panel bearing the portrait of a saint.... [Its] origins were of great antiquity, deriving from the kind of painted Roman portrait... [on mummys] and the mosaic portrait medallions conspicuous in Byzantine churches.... [Later] the iconostasis... was to enable the worshiper to read pictorially.

Blake adapts this iconographic system to his iconic color plates as structural cues for the interpretation of his poesy. Iconography is "the study of the subject matter of and symbolism in works of art," whose ancillary function is to trace influences in order to assign dates and suggest origins. While dates are incidental to the purpose of this study, the consideration of certain influences is integral; therefore, I intend to concentrate on the genesis,

8 Louise Gardner, Art through the Ages, 7 th. ed. (New York: Harcourt Brace Jovanovich, 1980) 250-251.

9 Louise Gardner, Art through the Ages, 7th. ed. (New York: Harcourt Brace Jovanovich, 1980) 5 . 
significance, and impact of specialized symbolism in the eight color plates and to evaluate its effects on imaginative vision.

As Blake's plates communicate imagistically and his poesy expresses linguistically, yet both are interpreted conceptually, different perceptual states are vectors in dynamic tension on the same continuum, since "vision does not travel in a straight line, but oscillates between contrary forces, converging on a moment of illumination. Thus, 'Fear and Hope are--Vision!'(GP, E. 263)."10

Congruent with biblical, visionary time, Blake's art achieves a monumental quality; the "intellectual strife of contraries," constitutes his interpretation of eternity." The visionary cast, consistent with an emphasis on the nonspatial orientation of imagination, is enhanced by eidetic elements in his plates. The focus of eidetic imagery is a dominant form of surreal vividness discrete from its surroundings by virtue of intense color contrast devoid of an obvious source of illumination, like the startling impact of a cochineal cactus bloom in yellow ochre desert. Unlike other kinds of mental imagery, the eidetic form is

10 W.J.T. Mitchell, Blake's Composite Art: A Study in the Illuminated Poetry (Princeton: Princeton University Press, $1978) 72$.

11 Rachel V. Billigheimer, "Blake's 'Eyes of God': Cycles to Apocalypse and Redemption," Philological Quarterly, William Kupersmith, ed., vol. 66, no. 2, Spring, 1987 (Iowa City: The University of Iowa, 1987) 236. 
derivative of "a visual image persisting after stimulation, relatively accurate in detail, colored positively, and capable of being scanned."12

The precise focus of this study is Blake's original combination of iconography and eidetic imagery in eight color plates, which present several versions of the human form as icons to illustrate transformative aspects of visionary imagination. As I examine the series of plates, I follow the way in which Blake's recurrent symbols of eyes and vortices develop his theme of visionary imagination. Blake's combination of these motifs, integral to biblical symbolism embedded in Gothic iconography, his eidetic imagery, and High Gothic iconic style coalesce into his artistic production of an individualized human form, whose relative scale is reminiscent also of Gothic statuary. This monumentality provides the heroic proportions which Blake believes suitable accompaniments to his narrative epics. These epics, together with his poem, "The Divine Image," form the most pertinent sources for interpreting the image and word as expressions of body and soul in his visually narrative plates.

Blake insinuates allegorical meaning into his plates as actual color, analogous to fleshed body, in specialized hues of red and gold not seen elsewhere in his illustrations.

12 Ralph Norman Haber and Ruth B. Haber, "Eidetic Imagery: I. Frequency," Perceptual and Motor Skills (Austin: Southern Universities Press, 1961) 138 . 
This emphasis on the importance of color to flesh the body, rather than merely to clothe it, is consistent with its being an integral component of eidetic imagery. But Blake typically infuses further meaning into his plates, until such trompe de l'oeil aesthetic impact as the image of a scarlet cactus in golden sand becomes additionally charged with symbolic significance; while this is characteristic of the method of traditional Gothic iconography, Blake appropriates the technique in order to present his unique mythopoeic vision. His ironic opposition of standard systems of codification with an eccentric recombination of eclectic material is far different from the bricolage method referred to by Claude Lèvi-Strauss; accordingly, Blake's intense color contrast of reds and golds intends complex, idiosyncratic symbolism. As I shall demonstrate, with Blake's plates it is desirable, in contradistinction to Imlac's advice, exactly to "number the streaks of the tulip."13 Blake more than most poets is concerned precisely with those sorts of minute particulars that identify the individual, as well as with the poet's task of observing "the species; [and the need] to remark general

13 Samuel Johnson, Rasselas, The Streaks of the Tulip: Selected Criticism, william Jay Smith (Seymour Lawrence: Delacorte Press, 1972) ix. 
properties and large appearances."lt

The value of this study to fill the gap in Blake studies is its unique insights, but it depends especially on understanding certain aspects of Gothic. Unlike the critics who have emphasized literary Gothic and the illuminated manuscripts, I examine Gothic iconographical and architectural influences as Blake combines these with idiosyncratic eidetic imagery in his iconic plates to dramatize the unifying power of visionary imagination. Iconographical analysis deals with "images, stories and allegories instead of with motifs... It presupposes a familiarity with specific themes or concepts as transmitted through Iiterary sources," 15 either read or by oral tradition. Blake draws on both literary and oral sources from several disciplines in an iconoclastic act to demonstrate the universality of the human condition. My method of interpretation will include the "synthetic intuition" approach, which involves "(familiarity with the essential tendencies of the human mind), conditioned by personal psychology and 'Weltanschauung.'"16 The single

14 Samuel Johnson, Rasselas, The Streaks of the Tulip: Selected Criticism, William Jay Smith, (Seymour Lawrence: Delacorte Press, 1972) ix.

15 Erwin Panofsky, studies in Iconology: Humanistic Themes in the Art of the Renaissance (New York: Harper \& Row, 1965) 11 .

16 Erwin Panofsky, Studies in Iconology (New York: Harper \& Row, 1965) 15 . 
most profound structural influence on Blake's work is the Gothic architecture which he sketched during his seven years' apprenticeship to James Basire in the 1770 s at Westminster Abbey and its Tombs with their High Gothic (c. 1200-1300) ornamentation and the added Late Gothic (c. 13001500) Henry VII Chapel. There is an "organic, 'flowing' quality of the High Gothic interior"; ${ }^{17}$ its suffusion with stained glass light suggests harmony between structural coherence and implied spiritual presence. Blake adapts this metaphor of illumination to his plates; unlike the transmitted light of stained glass, the light in paintings is reflected, but translucence can be implied through the light and dark effects of chiaroscuro.

But it is not only Gothic architecture, icons, and stained glass which affected Blake's style. Apart from the monumentality of Blake's central human forms, typical of Gothic statuary, the plates' linearity of design resembles "medieval bas-relief (or Wedgwood frieze) which entangles the figure in a relatively two-dimensional background." 18 This frieze effect recurs throughout his icons; it is underscored by Blake's insistent use of the "bounding line" congruent with Gothic's firm outlines to demark the

17 Louise Gardner, Art through the Ages, 7th. ed. (New York: Harcourt Brace Jovanovich, Publishers, 1980) 327.

18 W.J.T. Mitchell, Blake's Composite Art: A Study of the Il luminated Poetry (Princeton: Princeton University Press, 1978) 48 . 
symmetrical iconic figure from its formally stylized background. His "bounding line" delineates the human form visually as container of incarnate spirit, to differentiate it from its surroundings, as a counterpart to the poetic separation of true vision from the "indefinite." This "bounding line" automatically exists as the frame to Blake's plates, so that image (body) and poesy (soul) need to be interpreted and integrated through the transformative power of visionary imagination. Poetically, Blake announces this visionary state with the declamatory, omniscient voice:

"Hear the voice of the Bard! who Present, Past, \& Future sees."19 Visually, Blake dramatizes this visionary realm with the monumental image: The quatro-headed Zoa-Cherubim stands erect amid swirling eye-vortices in Ezekiel's wheels (Figure 1); caduceus-like he glares with cosmic consciousness through the opening center of the vortex into eternity. Iconographically, Blake reveals the process of visionary imagination to demonstrate congruence between image and word in Adam Naming the Beasts (Figure 2). By

19 William Blake, "Introduction," Songs of Experience, Blake's Poetry and Designs, Mary Lynn Johnson and John E. Grant, eds. (New York: W.W. Norton \& Company, Inc., 1979) 40. 


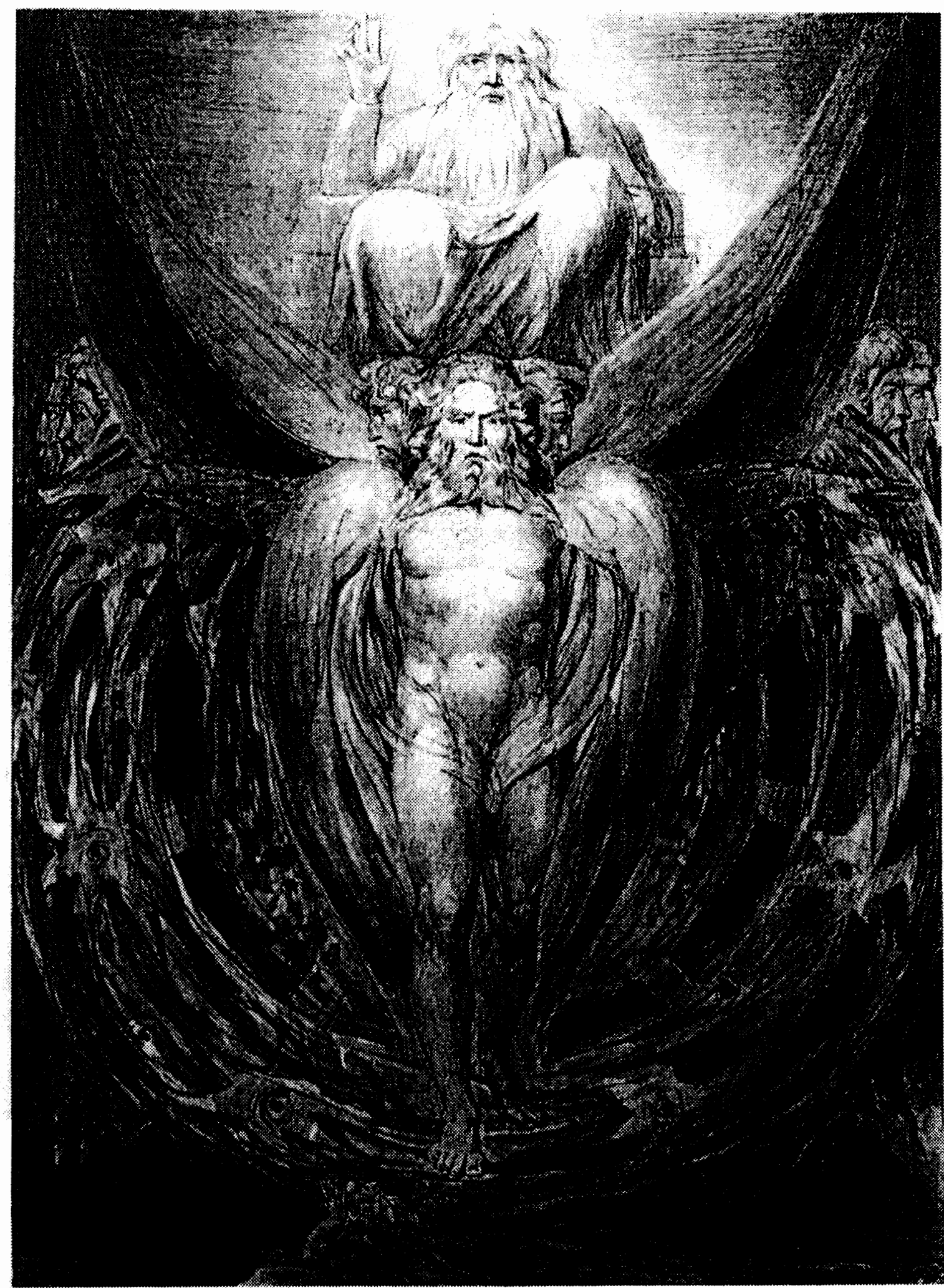

Figure 1. Ezekiel's wheels. 


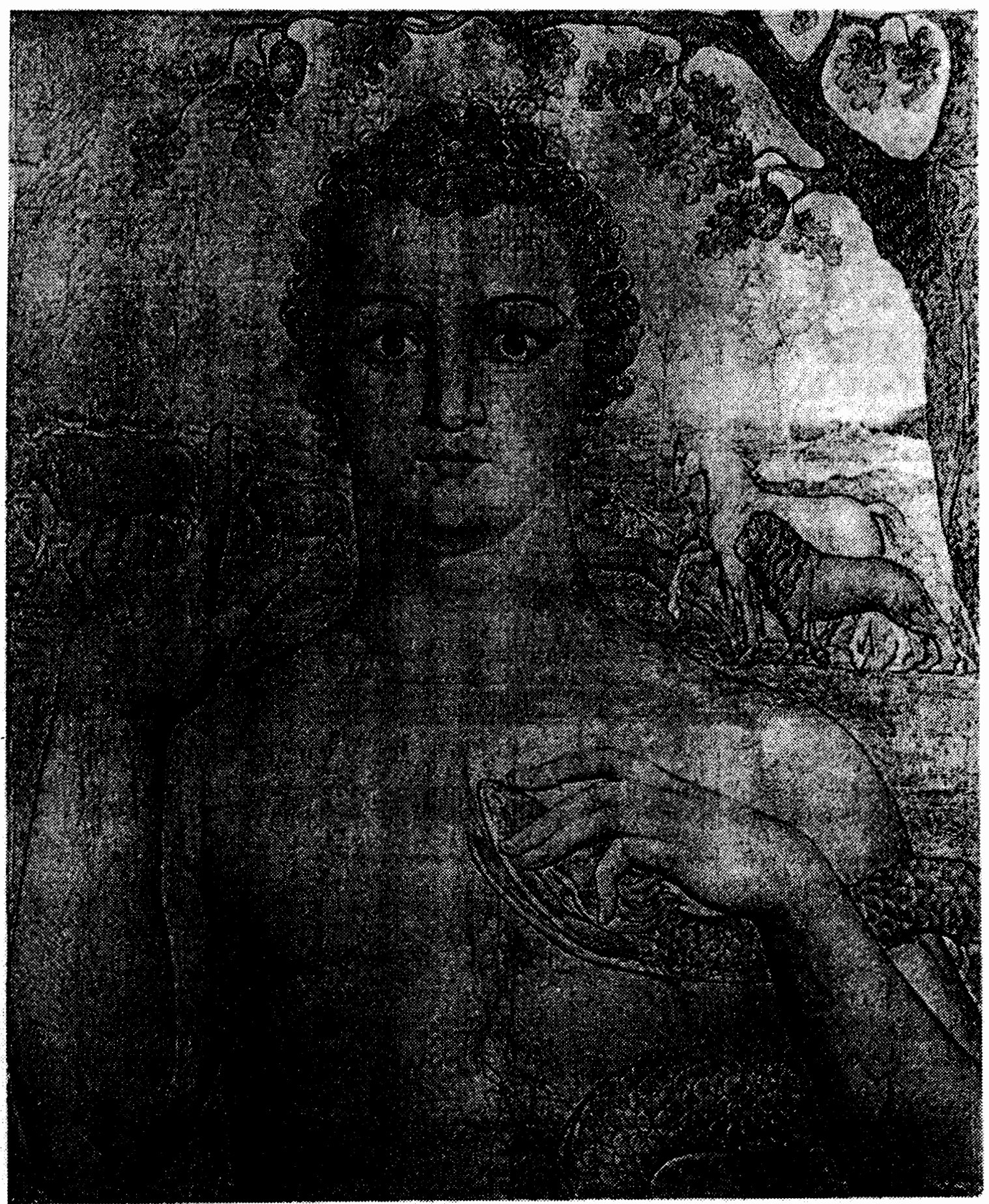

Figure 2. Adam Naming the Beasts. 
naming them, Adam brings animals into existence; this demonstrates that formed ideas become images, as "Blake saw the relation of the verbal to the pictorial much as he did the relation of the spirit or soul to the body."20 Adam's performative gesture is arrested in the process of signalling creatures into existence in Adam Naming the Beasts (Figure 2) as his index finger is suspended during the process of naming ideas (poesy) into forms (images). Blake orders ideas into images through the action of his creative poetic talent illuminated by visionary imagination, which he dramatizes in his iconic plates. I show that his dual, complemetary art forms a unified whole by interpreting the eight color plates as bodies informed by the soul of his poesy. To appreciate his method, it is essential to understand that his idiosyncratic cosmology is influenced by a combination of several elements: the blend of pagan and biblical symbols in Gothic iconography; the naturalistic High Gothic statuary, tapestries, and icons; and his characteristic eidetic imagery, which reflects his humanistic philosophy. He opposes his idiosyncratic distortion and elaboration of these various elements to the tyranny of religious orthodoxy, Greek rationalism, mechanistic physics, legalistic codification, and the

20 Edward J. Rose, "Blake's Biblical Consciousness and the Problem of the Interpretation of Text and Design," Bucknell Review: Criticism, History, and Intertextuality, Richard Fleming and Michael Payne, eds. vol. 31, no. 1 (Lewisburg: Bucknell University Press, 1988) 114 . 
hypocritical elitism of hierarchical structures. The failure of the critics to study the synergystic effects of these iconographic and eidetic influences in Blake's plates ignores the most fundamental components apparent in this body of his visual art.

To understand the complexity of Blake's plates, it is necessary to know something of his iconography. As indicated, he paints in the tradition of the iconostasis ${ }^{21}$ with intense colors and precise shapes which need to be deciphered according to his poetic text. I interpret the eight color plates according to Erwin Panofsky's definition of "synthetic intuition" 22 by incrementally examining their elements in sequence. I begin with a discussion of the specific aspects of Gothic iconography and Gothic statuary which influence his plates; I then consider the nature of eidetic imagery and evaluate its relevance to Blake's vision; next, I look at the combined influence of Gothic and eidetic imagery on Blake's plates. I show that his controlling metaphor for their structure is based on his system of four Zoas, in turn derived from biblical exegesis

21 The iconostasis is a "large icon-bearing screen that shuts off the sanctuary from the rest of the church.... The purpose of these paintings was to enable the worshiper to read pictorially. Clear pictorial legibility in wavering candlelight and through clouds of incense required strong pattern, firm lines, and intense color," Louise Gardner, Art through the Ages, $7 \mathrm{th}$. ed. (New York: Harcourt Brace Jovanovich, Publishers, 1980) 251.

22 See definition and footnote $\# 15$ above, page 7 . 
imagistically inscribed in Gothic iconography. I refer to his epics Jerusalem and The Four Zoas to demonstrate that the Zoas recur as integral motifs suggested by specialized color and symbolic designs throughout his plates. In evaluating the unifying and transformative power of visionary imagination in Blake's work, I concentrate on eye and vortex symbolism, together with his specialized hues of red and gold.

In the final section, on three key Blake plates, I draw all this information together into a precise explanation of the nature of Gothic influences and eidetic imagery on Blake's depiction of unified man as the "Human Form Divine." I show how this is accomplished through the transformative power of visionary imagination. By focussing attention on these three iconic plates as a triptych to be interpreted especially in light of his epics, and as they illustrate his poem "The Divine Image," I indicate how Blake also unifies body and soul as he transforms his viewer; I show how he accomplishes this, particularly through the reciprocal mirroring action of eyes, to initiate visionary imagination which he dramatizes in its three phases. In the beginning, the created man Adam is suspended during his own act of creation in Adam Naming the Beasts (Figure 2); centrally positioned, the begotten man Jesus is depicted as generic human begetting imagination in Christ Blessing (Figure 3); at the culmination stands regenerate man Albion, who 


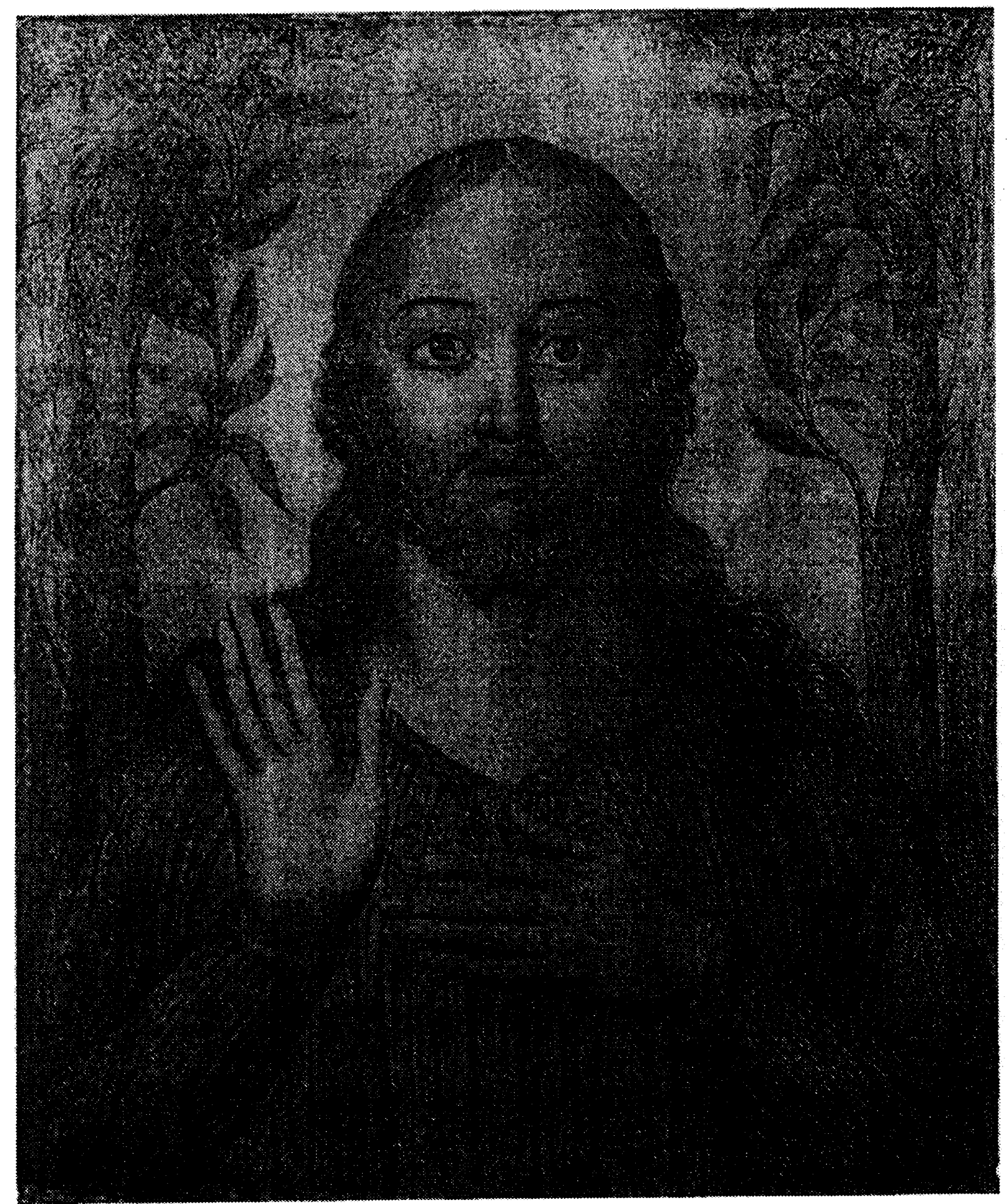

Figure 3. Christ Blessing. 
represents a type of the risen Adonis-Dionysus-Christ figure, ecstatically revealing the ubiquitousness of divinity as an inner state in The Dance of Albion (Figure 4). As a touchstone, I will refer regularly to Ezekiel's Wheels (Figure 1), since this plate represents the finest visual distillation of Blake's entire cosmology. 


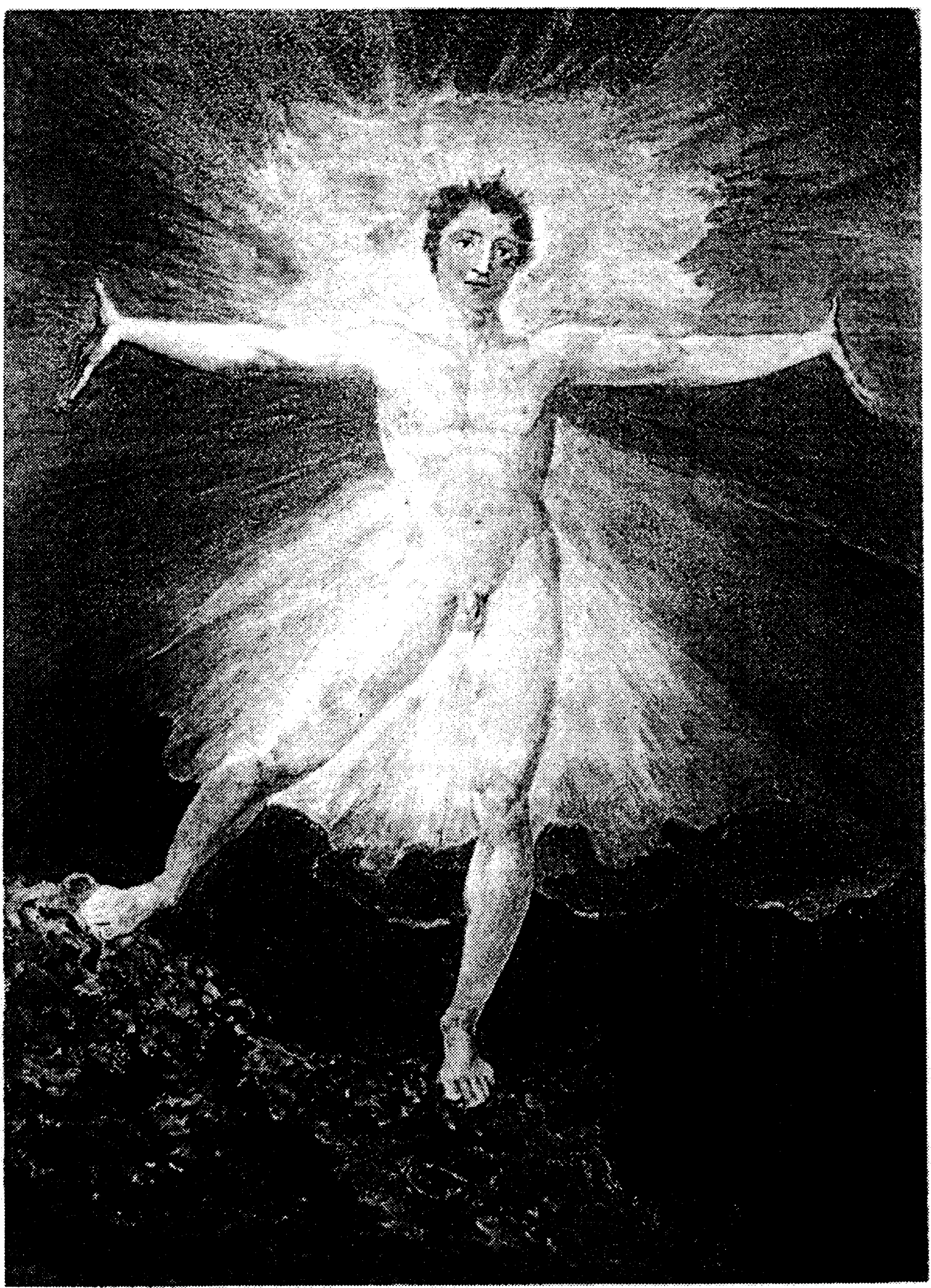

Figure 4. Glad Day or The Dance of Albion. 
THE PLATES

\section{GOTHIC INFLUENCES, ZOAS, AND EIDETIC IMAGERY}

Blake's Ezekiel's Wheels (Figure 1) and Adam Naming the Beasts (Figure 2) are the most exquisite visual crystallizations of his iconography. His plates demonstrate a similar aphoristic quality to his poesy; in fact, Northrop Frye considers Blake to be perhaps "the finest gnomic artist in English literature."23 This economy of style and compression of image are apparent as Blake projects his cosmology onto Ezekiel's visionary realm in Ezekiel's Wheels (Figure 1) and literalizes his own creative process in Adam Naming the Beasts (Figure 2). His artistic paradigm derived from Gothic structuralism as interpreted through fourfold biblical exegesis became the controlling metaphor for his system of Zoas. He deliberately distorts biblical iconography; as Los, his narrative voice announces in Jerusalem "I must Create a System, or be enslaved by another Man's. / I will not Reason \& Compare: my business is to Create." 24 This is the core of Blake's philosophy with its

23 Northrop Frye, Fearful Symmetry: A Study of William Blake (New Jersey: Princeton University Press, 1974) 5.

24 William Blake, Jerusalem: The Emanation of the Giant Albion, Plate 10, lines 20-21, Blake's Poetry and Designs, Mary Lynn Johnson and John E. Grant, eds. (New York: W.W. Norton \& Company, Inc., 1979) 316 . 
emphasis on the supremacy of the creative act versus the discriminative method of sceptical rationalism.

Accordingly, Blake's unique plates need to be understood through his idiosyncratic adaptation of traditional biblical exegetical iconography distilled in his epics of Jerusalem and The Four Zoas. His emphasis on the originality and "living form" of Gothic is metaphorized through his four Zoas based on the living beasts derivative of Revelation; this, combined with the visionary effects of eidetic imagery, particularizes his plates as imagistic counterparts to his poesy. The images embody his poesy in a sort of artistic incarnation. Since understanding comes through insight, knowledge of divine essence is possible through the genius of imagination; by dramatizing visionary imagination, Blake reveals this essence. Northrop Frye compares Blake's art to a spiritual discipline like yoga, "which liberates man by uniting him with God." 25 Ezekiel's Wheels (Figure 1) illustrates this spiritual significance most clearly with Blake's characteristic symbolic use of cosmic eye motifs; congruent with Northrop Frye's premise, the vision of eyes in wheeling vortices is remarkably similar to Hindu descriptions of raja devas. Blake's Cherubim is quatroheaded to represent the unification of Blake's Zoas. These

25 Northrop Frye, Fearful Symmetry: A Study of William Blake, 4th. ed. (Princeton: Princeton University Press, 1974) 431 . 
Zoas inform all of his work; thus, a basic understanding of the significance of his Zoas is critical to an appreciation of the complexity of Blake's plates.

Blake's development of his Zoa-schema of man's fourfold nature composed of wisdom, love, imagination, and strength from the biblical four beasts around the heavenly throne in Revelation is unique. He represents an original voice in the historic continuum of usage of this philosophicoliterary convention of fourfold categorization ${ }^{26}$ codified in the second century. ${ }^{27}$ Taking this interpretative organizing principle inward to the psychological level, Blake adapts it to the consciousness within man, which dictates external order subjectively. Consciousness individualizes derivative or congruent concepts: Protagoras' "Man is the measure of all things, of things that are that they are, of things that are not that they are not," 28

26 Its adaptation to describe human nature predates Galen (A.D. 129-ca. A.D 199), who codified the theory of four humours in man in the second century. In the seventeenth century, Ben Jonson elaborated on this basic schema to perfect the traditional attribution of types; used notably by Aesop in his Fables, it is a method of satirizing the human condition based on its portrayal as an anthropomorphized creature. In the twentieth century, Paul klee capitalized on the mythopoeic device in Twittering Machine.

27 Frederick Copleston, S.J., A History of Philosophy, Book 1, vol. 1: Greece and Rome (New York: An Image Book, Doubleday, 1985) 427 .

28 Protagoras, On Truth, A New History of Philosophy: Ancient and Medieval, Vol. 1, Wallace I. Matson (New York: Harcourt Brace Jovanovich, Inc., 1987) 68. 
which indicates a process whereby the mind evaluates reality, is transformed into the idea of reciprocity between mutating intellect and visual perception expressed as "the eye altering, alters all." Likewise, since Blake's patterning is derivative of the four levels of biblical exegesis, his model for the archetypal psyche also has a fourfold pattern. It is natural, then, that Blake's cosmology should be perceived through his mind's projected categorization as fourfold. ${ }^{29}$ Blake depicts his allegory of the four-fold vision or perception of the world as interpreted through the human mind with his specialized use of color, compass direction, and other fourfold symbols in his plates; ultimately, their unification becomes the "Human Form Divine." Recognition of Higher Innocence, the blissful state of spontaneous individuality in harmony with its esse, ${ }^{30}$ comes through the visionary imagination which initiates regeneration. The fourfold categorization adapted to theologica' literature, which Blake appropriates, is derived from the Medieval convention based on St. Thomas Aquinas's account of the four levels of biblical

29 See Bastian on "Elementary Ideas," Lèvi-Strauss on anthropological structuralism, Carl Jung on Archetypes and the four functions of consciousness, and Joseph Campbell on "the ground of being."

$30 \mathrm{~s}$. Foster Damon defines esse as the individuality which is "unique, eternal, and therefore uncreate and indestructible," A Blake Dictionary: The Ideas and Symbols of William Blake, Rev. ed. (Hanover: University Press of New England, 1988) 196 . 
interpretation, the four-fold exegesis: ${ }^{31}$ the literal, the allegorical, the moral, and the anagogical; this fourfoldness is personified by Blake's Zoas. The image of The Four Beasts of Revelation, the immediate paradigm for Blake's The Four Zoas, ${ }^{32}$ is profoundly striking. In Greek, zoa means beast, ${ }^{33}$ which pertains specifically to

Revelation $4: 6$ :

And before the throne there was a sea of glass like unto crystal: and in the midst of the throne, and round about the throne, were four beasts full of eyes before and behind.

But the origin of this Zoa-fourfoldness is even more ancient than Blake's largest, single source of Revelation, since "before Ezekiel, the huge statues of the guardians of the Assyrian palace gates were sculptured with the face of a

31 Barbara Kiefer Lewalski, Protestant Poetics and the Seventeenth Century Religious Lyric (Princeton: Princeton University Press, 1979) 8 .

32 Harold Bloom, Blake's Apocalypse (New York: Doubleday \& Company, Inc., 1963) 250 .

33 S. Foster Damon provides philological information about the origin of Blake's construct of four unified archetypes: "ZOA is a Greek plural which Blake used as an English singular. In Revelation (iv:6, etc.) it is awkwardly translated 'beasts.'... These beasts are the same four 'living creatures' (Chayot Hakodesh) which Ezekiel beheld by the river of Chebar (Ezek i:5 ff., J 12:58). They have complicated eyed wheels within wheels, which revolve independently, and act as the chariot of Deity." A Blake Dictionary: The Ideas and Symbols of William Blake, Rev. ed. (Hanover: University Press of New England, 1988) 458.

34 Revelation 4:6, Holy Bible, King James's Version (London: Eyre and Spottiswoode Limited, n.d.) 306. 
man, the head of a lion, the wings of an eagle, and the body of an ox." 35 These Zoas remain recognizable historically from ancient to modern times as the four fixed signs in the Occidental zodiac of Aquarius, Leo, Scorpio, and Taurus because of their association with the four basic elements of air, fire, water, and earth. These four zoa of Revelation as they transform to become Blake's personifications for his four Zoas of Tharmas, Urizen, Luvah, and Urthona in his Jerusalem and The Four Zoas are humanized in pairs at either side of the hieratic figure of the Cherubim to echo or amplify his Zoa-headedness, in Ezekiels Wheels (Figure 1). Often symbolized only in color, Blake's Zoas represent aspects of man, since they are the distillation of Blake's fundamental humanistic philosophy and represent toward the conclusion of The Four Zoas the culmination of his artistic schema. As psychic aspects, they ultimately become reintegrated within the unified, archetypal man as symbolized by Albion; the mythical patriarch of Britain and "latent hero"36 of The Four Zoas is surrounded by or emanating a cosmic aureole of regenerative energy in his joyously uninhibited state in Glad Day (Figure 4). The presence of the integrated Zoa-aspects of his being is

35 S. Foster Damon, A Blake Dictionary: The Ideas and Symbols of William Blake, Rev. ed. (Hanover: University Press of New England, 1988) 458 .

${ }^{36}$ Harold Bloom, Blake's Apocalypse (New York: Doubleday \& Company, Inc., 1963) 252 . 
insinuated through the diffusing primary colors of his fourfold sunburst halo. Blake indicates Albion's human state, as opposed to his manifesting in the purely visionary realm composed of spirit such as the figure of the Cherubim, by the blue organic hyle beneath Albion's feet; this is symbolic of the Zoa Tharmas' presence, whose association is with the material realm.

In addition to its zoa, Blake appropriates the apocalyptic method of Revelation, which Jacob Bronowski points out is oratorical allegory:

This proliferation of meanings, unfolding from one skein, is an orator's trick.... one must learn to
read Blake's prophetic manner as rhetoric.

Blake's rhetoric is woven throughout the plates, which provide visual cues to his developing humanistic philosophy; the skein of meaning must be unravelled through an informed reading of his allegory (poesy) made flesh (image). His combination of Gothic iconographical, Hebrew Cabbalistic, and Alchemical symbols, together with vivid eidetic effects and idiosyncratic use of color, are separate but integral threads in the skein. These threads are woven into the looser fabric of his epic poetry, which provides a broader structure for his humanistic philosophy than the compact tapestry of his iconic plates. However, his eight color plates gain intensity by their compression of peculiar

39 Jacob Bronowski, William Blake and the Age of Revolution (New York: Harper \& Row, 1965) 30 . 
iconography, Gothic influences, specialized hues of red and gold, as well as idiosyncratic eidetic imagery.

Blake expresses his humanistic philosophy according to the Romantic principle of creative organic tension between contraries. Jacob Bronowski believes that the ethos of the revolutionary times, with their dual evils of mechanism and war involving opposing forms of rationalism, underlies Blake's philosophy of contraries:

Blake's writings grew within the French Revolution and the Industrial Revolution. In these, in the two kinds of rationalism, and in the two kinds of dissent, lie the roots of his thought. From these roots grew his dialectic of contraries and progression, some form of which is common to all mystics.

While despising mechanism and war, Blake sees revolution in creative terms as the active force which springs from energy. He perceives evil in terms of hindrance and restraint. Harold Bloom expresses this Romantic principle, which is the interface of Eros and Thanatos energies in mythological terms, in Pre-Socratic philosophical terms as the productive Prolific which would cease to be itself, would stifle by its own exuberance of invention, if the Devourer ceased to be a primal sea into which the Prolific delights could be received. ${ }^{39}$ Accordingly, as Blake opposes ecstasis and anastasis to stasis, his art gains

38 Jacob Bronowski, William Blake and the Age of Revolution (New York: Vintage Books, 1965) 188 .

39 Harold Bloom, Blake's Apocalypse (New York: Doubleday \& Company, Inc., 1963) 63 
visual dynamism. Analogous to the experience of entering an actual Gothic cathedral, Blake's iconographical paradigm, Blake's artistic skein mutates and expands in scope, complexity, and physical size as the mythopoeic vision inscribed in his plates develops and exfoliates throughout his lifetime. While the Medieval tradition of illuminated manuscripts influenced Blake's early productions prior to 1800 , his later work developed Medieval design motifs more broadly to integrate his adaptation of the Medieval convention of iconography visually as well as poetically into an "encyclopedic symbolism [like that] of the Gothic cathedrals." 40 Like the Gothic cathedral and icon, the focus of his art is implied spiritual essence. David Sten Herrstrom observes that "Blake conceives of art as Incarnation, the Word made flesh, [therefore] his work is intended to have the unity of a body, or, as he says, 'Naked Beauty displayed." "1!

His art intends to reveal truth; the range and strength of his pure color hues mimic the sun's brilliance, most obviously in Glad Day (Figure 4), since this symbolizes

40 Northrop Frye, Fearful Symmetry: A Study of William Blake, 4th. ed. (Princeton: Princeton University Press, 1974) 110 .

11 David Sten Herrstrom, "Blake's Redemption of God in the Laocoön: Literal Incarnation and the Marriage of Picture and Text," Bucknell Review: Criticism, History, and Intertextuality, Richard Fleming and Michael Payne, eds. vol. 30, no. 1 (Lewisburg: Bucknell University Associated Presses, 1986) 39 . 
spiritual illumination. However, since human awareness of this truth of man's incarnate divinity becomes veiled, Blake sometimes conceals essence ironically in his plates (body) as incarnation of his words (soul) in order to stimulate insight through his dramatization of visionary imagination. Blake's concept of Beauty is a means of communication, for "Beauty is the spark at contact, marking the mystical union of poet and reader. All art exists at that point and nowhere else."42 This is Beauty as Truth in the classical tradition conveyed through Plutarch's dissemination of the ancient idea of painting as dumb poesy and poesy as a speaking picture. As S.K. Heninger, Jr. observes, there is a dialectic between poetry and painting:

And although language cannot fully reproduce physical reality, and in this attempt poetry and even history are inferior to painting

Rhetoric...[provides] a common denominator for the conflatign of poetry and painting as semiotic systems.

This sense of the conflation of Truth with Beauty is personifeid in Christ Blessing (Figure 3); Jesus is shown as a fleshly being, devoid of stigmata, very unlike the earlier Gothic icons or their predecessors, the highly

$12 \mathrm{~S}$. Foster Damon, A Blake Dictionary, Rev. ed. (Hanover: University Press of New England, 1988) XXV.

13 S.K.Heninger, Jr.,"Speaking Pictures: Sidney's

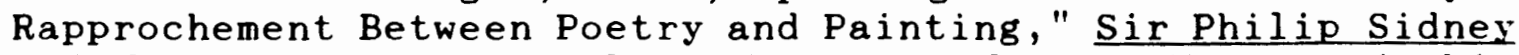
and the Interpretation of Renaissance Culture: The Poet in his Time and in Ours, Gary F. Waller and Michael D. Moore, eds. (London: Croom Helm; Totowa, New Jersey: Barnes and Noble, $1984) 11,13$. 
formalized Byzantine icons. Christ is the human Jesus

illumined with inner divinity; his appearance is

unexceptional as a personification of generic man; hence he is immediately approachable. Spiritual essence gleams

through his clear, direct eyes in Blake's imagistic

portrayal of "The Human Form Divine":

For Mercy has a human heart

Pity, a human face:

And Love, the human form divine

Love Mercy Pity Peace.

Then every man of every clime,

That prays in his distress,

Prays to the human form divine

Love Mercy Pity Peace."

This poetic statement of inner divinity is deceptively simple. It contains a compression of allusions as complex as Gothic iconography and should be deciphered in a similar manner. Christ Blessing (Figure 3) provides a visual cue or body for Blake's poetic word. The confrontational yet kind gaze of Jesus engages the viewer in a tacit communion; inner communication with one's own divine essence ensues; one realizes one's own spiritual source through the unifying power of imagination. In Blake's system of iconography, identification with the image of Jesus is mediated by the Zoa Los, personification of imagination in Blake's schema of the psyche. Since Los, who represents imagination, is identified with Jesus, by metaphoric extension Jesus becomes

14 William Blake, "The Divine Image," Songs of Innocence, Blake's Poetry and Designs, Mary Lynn Johnson and John E. Grant, eds. (New York: W.W. Norton \& Company, Inc., 1979) 30. 
the divine presence in all men because he is as imagined.

Traditionally, Jesus is presented in all phases of the biblical epic from Creation through Fall to Resurrection throughout Gothic iconography, so it is appropriate that Blake adapts its techniques, especially to his depiction of Adam, Jesus, and Albion as personifications of the three psychic stages of man. The complexity of Gothic architectural structure and iconographical decoration which were Blake's enduring artistic models reflect "a continuing adjustment of scale, proportion, buttressing, vault arrangement, and wall and façade design that, in Panofsky's image, is like the steps of a complex scholastic argument." 45 Congruent with this intricate reading of allusions in the Gothic iconographic tradition, Blake's plates demonstrate that "characters are a metaphoric utterance relating text and picture simply as name and image named." 46 Blake depicts this act of generation of visual images through the process of naming in Adam Naming the Beasts (Figure 2). This plate illustrates the iconic quality typical of some of his later art, in which "there

45 Louise Gardner, Art through the Ages, 7th. ed. (New York: Harcourt Brace Jovanovich, Inc. 1980) 321.

16 David Sten Herrstrom, "Blake's Redemption of God in the Laocoön: Literal Incarnation and the Marriage of Picture and Text," Bucknell Review: Criticism, History, and Intertextuality, Richard Fleming and Michael Payne, eds. vol. 30 , no. 1 (Lewisburg: Bucknell Universities Associated Presses, 1986) 40 . 
are emblematic elements in...design (the icons of classical

and Gothic architecture)."17 The High and Late Gothic influence, more naturalistic in treatment than earlier

Medieval and formalistic Byzantine icons, is most apparent in Blake's tempera icon of Christ Blessing (Figure 3), which is a graphic depiction of the human form radiating spirit for "Everything in Eternity shines by its own Internal light"; ${ }^{48}$ this is consistent with Blake's declaration that "Grecian is Mathematic Form: Gothic is Living Form." 19 The distinction lies in the latter's intuition of inner divinity which transcends the proofs required by rational logic, although Blake also despises the Grecian glorification of war and empire. As noted, Blake articulates Gothic's belief in body as temple of spirit with his art and poesy by dramatizing the visionary imagination particularly with symbolic eyes and vortices, as well as specialized hues of red and gold; intuition perceives ideas and glimpses spirit as shapes a-wing, which Thomas Nashe termed that "brightness [which] falls from the air"; this is the process of metaphysical vision, which Blake reveals in Ezekiel's Wheels

17 W.J.T. Mitchell, Blake's Composite Art: A Study of the Illuminated Poetry (Princeton: Princeton University Press, $1978) 29$.

48 William Blake, Milton, Plate 10, Copy C, line 16, Blake's Poetry and Designs, Mary Lynn Johnson and John E. Grant, eds. (New York: W.W. Norton \& Company, 1979) 251.

19 William Blake, "On Virgil," K778, A Blake Dictionary, S. Foster Damon, Rev. ed. (Hanover: University Press of New England, 1988) 167 . 
(Figure 1).

Blake shows that through the transformative power of the visionary imagination, contrary states may be experienced as complements, whose tension is necessary to organic vitality. His solution and method of portrayal both involve metaphysics; as Mircea Eliade indicates, this realization of the possibility for transcendence of oppositions is the beginning of philosophy:

Finally, it is important to note that the mediation between the contraries also presents a great variety of solutions. There is opposition, clash, and combat, but in certain cases the conflict is resolved in a union which produces a "third term," while in others the polarities seem to coexist paradoxically in a coincidentia oppositorum, or they are transcended, i.e., radically abolished or rendered unreal, incomprehensible, or meaningless.... This variety of solutions to the problems raised by the mediation between the contraries--and we must add also the radically "dualistic" positions, which refuse any mediation--merits a special investigation. For if it is true that any solution found to the crisis provoked by the awareness of polarities implies somehow the beginning of wisdom, the very multiplicity and the extreme variety of such solutions arouse the critical reflection and prepare for the coming of philosophy.

As dichotomy of body and soul is analogous to the distinction between brain and mind, which therefore need to be considered together, male and female oppositions are symbolically reconciled in the traditional symbol for the

50 Mircea Eliade, The Quest: History and Meaning in Religion, Midway Reprint (Chicago: The University of Chicago Press, 1984) 175 . 
mystical union of flesh and spirit, the androgyne. Blake's plates vivified with the meaning of his poesy present a visual symbol for this mystical concept; hence, "One productive strategy... is the simultaneous study of word and picture... The method is unassailable; those who wish to understand Blake must take him whole."51 Likewise, to understand the significance of the Cherubim in his Ezekiel's Wheels (Figure 1) as Zoa-headed, it is necessary to be aware of the epic symbology of Blake's Jerusalem. Blake makes clear that this zoa is a psychic archetype within man both in Jerusalem: "I see the Four-Fold Man"52 and in The Four Zoas: "Four Mighty Ones are in every Man." 53 Through the stimulated power of visionary imagination, the perceiver is able to see syncretistically; as Martin $K$. Nurmi observes, he has "'four-fold' vision, which enables him to see all of existence synoptically as one, as 'One Man." 54 This "One

51 Clyde R. Taylor, "Iconological Themes in William Blake," Blake Studies, Kay Long and Roger R. Easson, eds., vol. 1, no. 1, Fall, 1968 (Tulsa: University of Tulsa, 1968) 39 .

52 William Blake, Jerusalem: The Emanation of the Giant Albion, Plate 15, I ine 1, Blake's Poetry and Designs, Mary Lynn Johnson and John E. Grant, eds. (New York: W.W. Norton \& Company, Inc., 1979) 318.

53 William Blake, The Four Zoas "Vala: Night the First," line 4, Blake's Poetry and Designs, Mary Lynn Johnson and John E. Grant, eds. (New York: W.W. Norton \& Company, Inc., 1979) 216.

54 Martin K. Nurmi, "I. Blake's Ideal of Expanded Sense Perception," Blake's Poetry and Designs, Mary Lynn Johnson and John E. Grant, eds. (New York: W.W. Norton \& Company, Inc., 
Man" is simultaneously Los, Albion, and Jesus, and by metaphoric extension all humanity; since Los is the personification of the transformative imagination, he colors imagery of Albion as representative of political unity, and Jesus as the apotheosis of spiritual harmony. As mentioned, this metaphoric coloring in the poesy appears visually as specialized hues of red and gold in Blake's plates not apparent in his illustrations. The tendency of the 'warm' colors in the red and yellow range is to appear to advance, whereas the 'cool' colors in the blue range seem to recede; visually, Blake's integral use of red and gold tones brings the image forward to dominate the picture plane and demand focus, while allegorically emphasizing the immanence of spirit as an inner state.

Blake's allegories are set in biblical, polysynchronous time, since "In Blake's conception time is subordinate to inner vision"; he equates the end of time with the attainment of inner vision. ${ }^{55}$ He articulates this theme of transformation from mundane to cosmic vision with his eye and vortex symbolism; in Ezekiel's Wheels (Figure 1) the series of eyes in vortices coalesce into the dual significance of successive levels of insight toward the

1979) 556 .

${ }^{55}$ Rachel V. Billigheimer, "Blake's 'Eyes og Goid': Cycles to Apocalypse and Redemption," Philological Quarterly, William Kupersmith, ed., vol. 66, no. 2, Spring, 1962 (Iowa City: The University of Iowa, 1987) 236. 
opening into eternal time, for "The Expanding Eyes of Man behold the depths of wondrous worlds."56 He confounds rules regarding the temporal mode of literature with the spatial mode of visual art by infusing his plates with symbols which must be read or decoded as poesy; he uses eyevortex symbolism to imply the interface between temporalspatial with eternal time. Accordingly, "the a-temporal scrutiny of Blake's oeuvre is justified by his own refusal to consider his art as anything other than a unity." 5 ?

Although not chronological, the selected eight color plates are linked thematically by their iconography as lucid distillations of Blake's dramatization of visionary imagination to demonstrate the means for unification of body and soul.

Blake dramatizes visionary imagination by subverting the tradition of religious icons to his humanistic philosophy. As he centers man for his biblical icon series, Blake appropriates the High and Late Gothic style of greater naturalism in which, "Nature begins to come forward as

56 William Blake, The Four Zoas, "Night IX" Page 138, lines 24-25, Blake's Poetry and Designs, Mary Lynn Johnson and John E. Grant, eds. (New York: W.W. Norton \& Company, Inc., 1979) 233.

57 Clyde R. Taylor, "Iconographical Themes in William Blake," Blake Studies, Kay Long and Roger R. Easson, eds., vol. 1, no. 1, Fall, 1968 (Tulsa: University of Tulsa, 1968) 39. 
important, and man comes forward with it."58 This is particularly apparent in Blake's Adam Naming the Beasts (Figure 2). By concentrating the visual focus on the human form, Blake illustrates the centrality of divine man in a unified state, which Mary Lynn Johnson notes is synonymous with "the 'Divine Humanity,' whom they come to recognize as an inward presence." 59 This is intuited and revealed through the visionary imagination. Blake's emphasis on the human form as spirit incarnate is marked in his biblical series commissioned by Thomas Butts, which Blake executed during 1800-1806 in pen and watercolor. The second plate in this series, God Blessing the Seventh Day (Figure 5), is representative of the series and precursor to the divine presence made manifest in Adam Naming the Beasts (Figure 2) of the second series done in 1810-1825, also for Butts. Inner divinity is depicted in a more traditionally Byzantine manner in The Black Madonna, while Christ Blessing (Figure 3) is emphatically naturalistic in this group. Of Jesus in Christ Blessing (Figure 3) Andrew Kaufman reminds us that, "Jesus... is ordinarily identified in Blake's work with

58 Louise Gardner, Art through the Ages, 7th. ed. (New York: Harcourt Brace Jovanovich, Inc., 1980) 333 .

59 Mary Lynn Johnson, "Human Consciousness and the Divine Image in Blake's Watercolor Designs for the Bible: Genesis Through Psalms," The Cast of Consciousness: Concepts of the Mind in British and American Romanticism, Beverly Taylor and Robert Bain, eds. (New York: Greenwood Press, 1987) 20. 


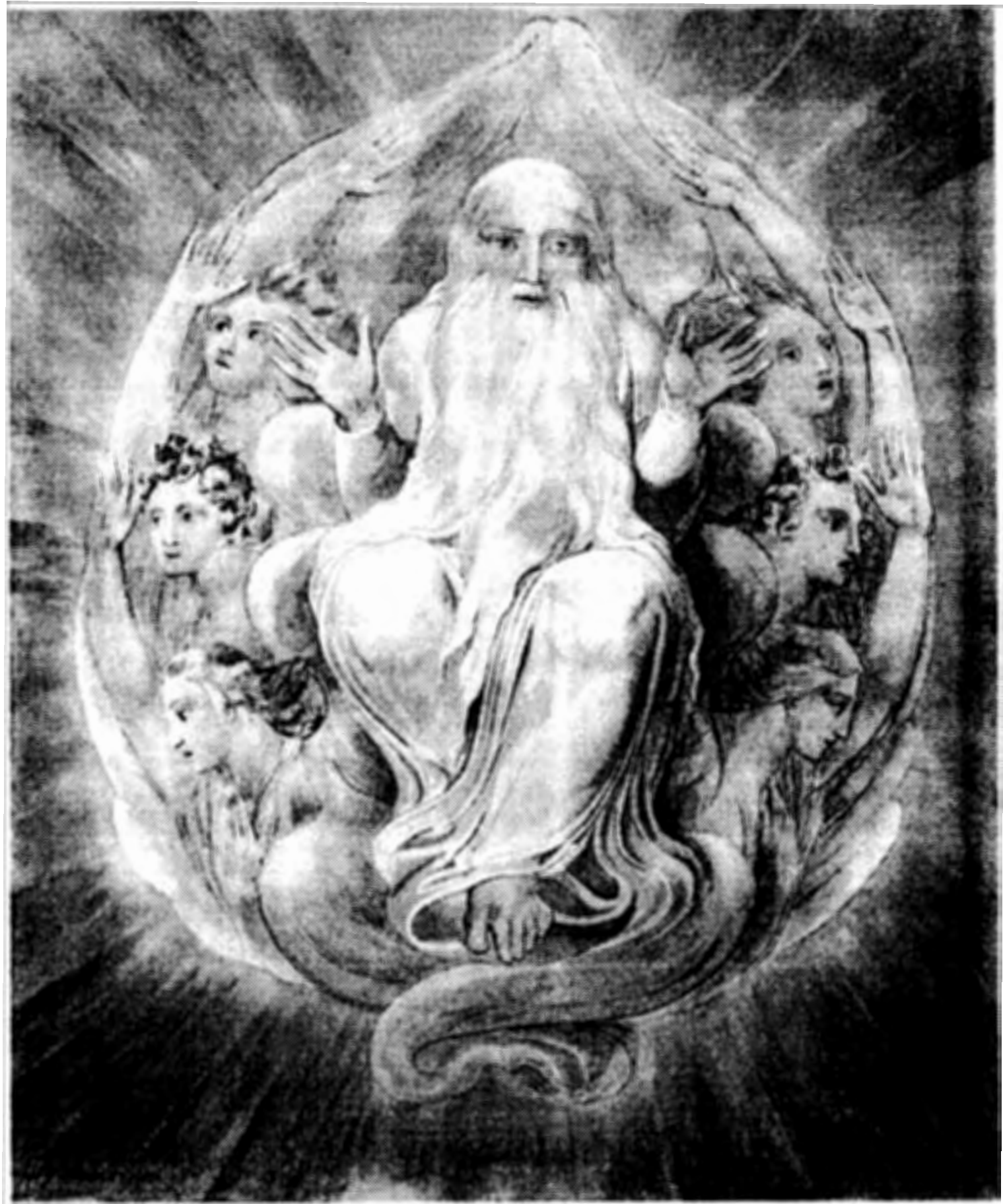

Figure 5. God Blessing the Seventh Day. 
imagination or 'the human form divine." "60 Commenting on its power, Raymond Lister indicates its connection with Blake's epic describing Albion's quest for reintegration: "it yet presents, in pictorial form, Blake's view of the divine man Jesus, as related in Jerusalem." 61

While the composition of Adam Naming the Beasts (Figure 2), Christ Blessing (Figure 3 ), and God Blessing the Seventh Day (Figure 5) does show the more naturalistic effects of Late English Gothic style and decoration, Blake's iconic figures are more than naturalistic in the Gothic manner; they have an almost surreal vividness typical of eidetic imagery. Discussion of eidetic imagery is necessarily speculative. Derived from the Greek eidetikos, which pertains to image, eidetic has already been defined as "a visual image persisting after stimulation, relatively accurate in detail, colored positively, and capable of being scanned." 62 But it is also three dimensional and sometimes manipulable in spatial orientation; however, only the

60 Andrew Kaufman, "Authority and Vision: William Blake's Use of the Gospels," University of Toronto Quarterly: A Canadian Journal of the Humanities, T.H. Adamowski, ed. vol. 57 , no. 3, Spring, 1988 (Toronto: University of Toronto Press, 1988) 398 .

61 Raymond Lister, The Paintings of William Blake (Cambridge: Cambridge University Press, 1986) 50.

62 Ralph Norman Haber and Ruth B. Haber, "Eidetic Imagery: I Frequency," Perceptual and Motor Skills (Austin: Southern Universities Press, 1961) 138 . 
individual experiencing it can be aware of it phenomenologically.

\section{The Ghost of a Flea}

The purported effects of this manner of perception are particularly demonstrable in Blake's painting of The Ghost of a Flea (Figure 6), since he claimed that the Flea was such a production. When compared with an actual flea, Blake's image is obviously an imaginative construct or the picture of an abnormal entity. It is a visual statement of Blake's ideology of the primacy of imagination and the nonamorphousness of spirit, since the Flea's authenticity as an actual eidetic image cannot be challenged. As only Blake saw it phenomenologically, it may or may not have conformed to the criteria which characterize eidetic imagery; it was a subjectively perceived mental image, if indeed it was actually seen with rather than through the eyes. Its presentation on a stage dramatizes its performative nature. Blake's use of eye motifs, symbolic of spiritual illumination, are minimalized or suggested by stars and comets on the scenery behind The Flea's plank stage. The absence of inner illumination emphasizes The Flea's spiritual diminution as reflected in its physical deformity; by contrast, the thick, luminous gilt overlay to the set's curtains and plank stage emphasizes externals in a similar way to the material focus achieved by the gem-encrusted 


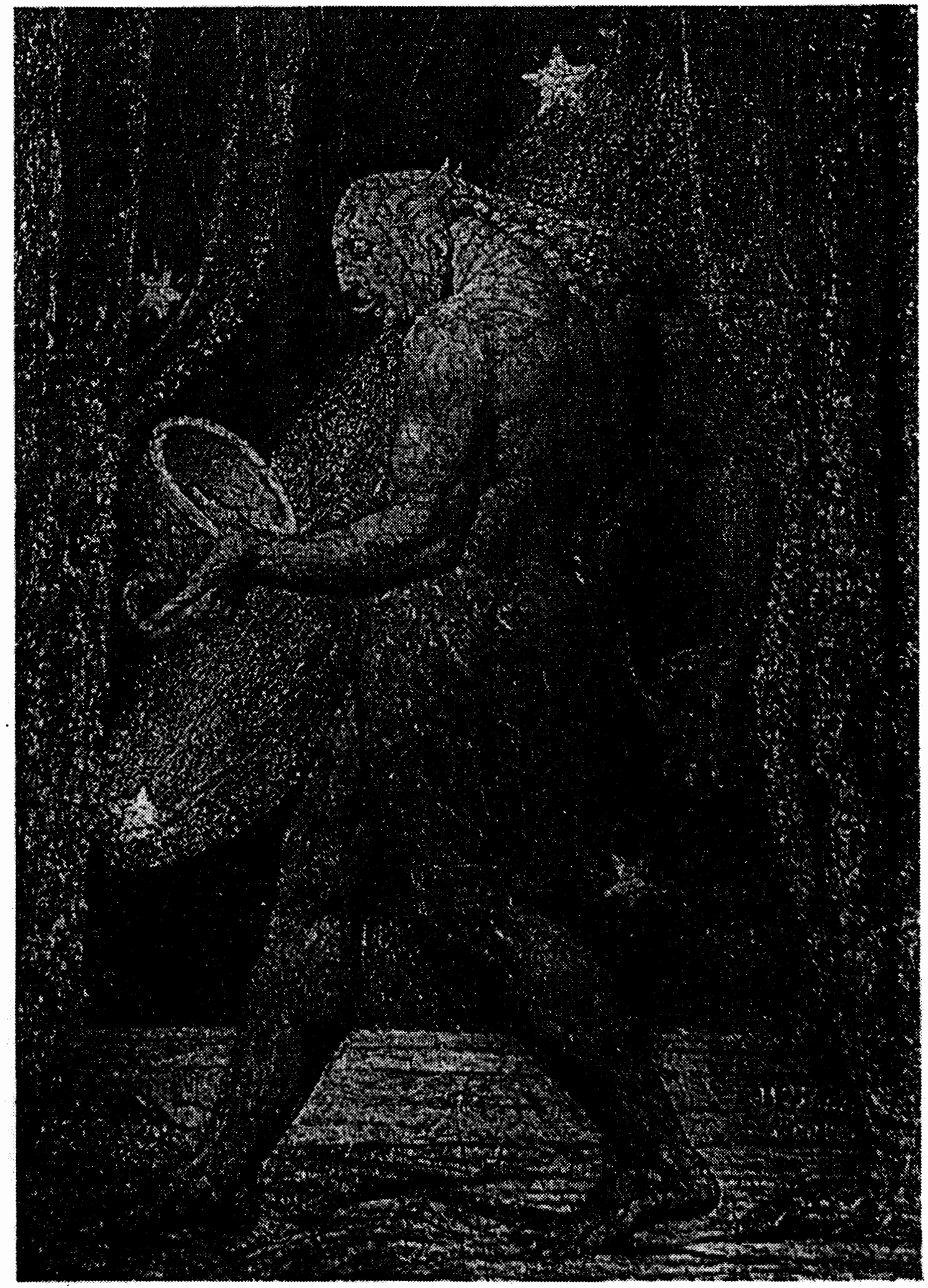

Figure 6. The Ghost of a Flea. 
adornments in Satan in His Original Glory (Figure 7). Typical of Blake's plates, the source of light within the painting is difficult to ascertain; this absence of 'external' light is typical of eidetic imagery, since mindpictures are non-preferentially lit and uncontaminated by distractions, arising in the mind's inner 'space' as if generated in a vacuum; consistent with their unconscious as opposed to sui generis origin, the central human form seems vivified. Symbolically, Blake uses the degree or intensity of the form's apparent emission of inner light to indicate its divinity or its paucity of spiritual illumination; visually, this technique is metaphorically like the distinction between "a brittle crazie glasse"63 which transmits radiance like sunlight through stained glass as opposed to "watrish, bleak, \& thin"64 light through opaque, painted glass. In The Ghost of a Flea (Figure 6), the dull stars and comets shooting diagonally as a backdrop from dexter to sinister, the direction of The Flea's stance and attention, symbolically reinforce its perverted nature, like that of Satan who "Startled the shades / Of Hell beheld him

63 George Herbert, "The Windows," English SeventeenthCentury Verse, Vol. 1, Louis L. Martz, ed. (New York: W.W. Norton \& Company, Inc., 1973) 1:2, 163 .

64 George Herbert, "The Windows," English SeventeenthCentury Verse, Vol. 1 (New York: W.W. Norton \& Company, Inc, 1973) $2: 5,163$. 


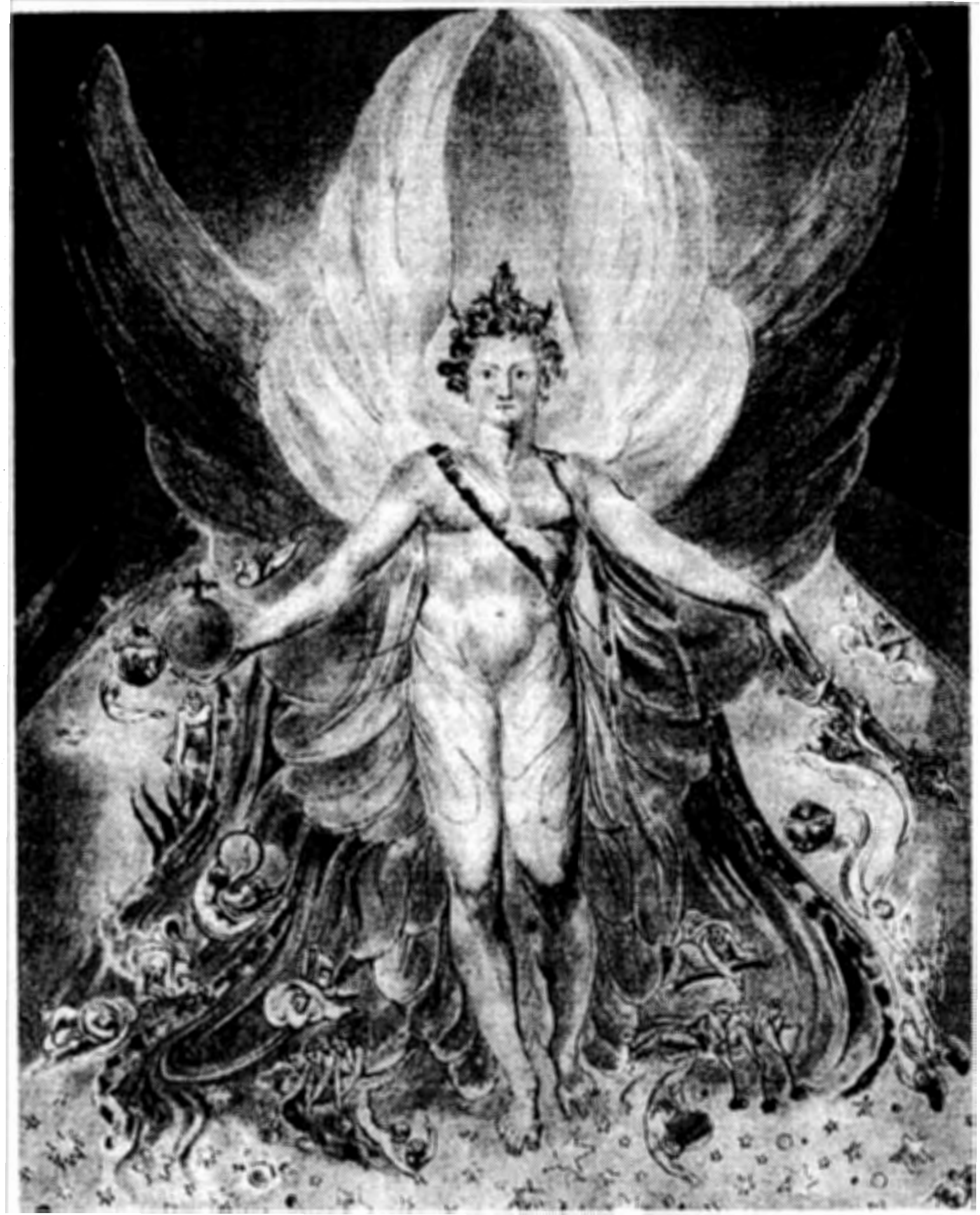

Figure 7. Satan in His or ginal Glory. 
in a trail of light as of a comet / That travels into Chaos." 65

The iconic quality of The Ghost of a Flea (Figure 6) argues against Blake's adoption of this stylized icon form being solely to replicate the traditional hieratic stance of central figures in Gothic iconic art in his other plates depicting human forms; another element is apparent in their staged manner, which is also congruent with eidetic imagery's surrealistic effects. The additional influence of Gothic apart from its iconic quality appears most obviously in the gargoylesque features in The Ghost of a Flea (Figure 6). This grotesque figure looks remarkably similar to some of the roughly chiselled, brooding and foreboding stone monsters through which water gurgled from cathedral roofs. Consistent with Gothic's placement of gargoyles as downspouts at the edges of roofs, there is no natural vegetation normalizing the Flea such as appears in Adam Naming the Beasts (Figure 2) or in Christ Blessing (Figure $3)$. The absence of a natural, organic setting places The Flea with forms in other plates which dramatize constructs generated totally in the imaginative realm, such as Satan in Satan in His Original Glory (Figure 7 ). The almost monochromatic golden brown hues of Satan and Flea emphasize their two-dimensional unreality, while insinuating the

65 William Blake, Milton Plate 15, Iines 18-30, Blake's Poetry and Designs, Mary Lynn Johnson and John E. Grant, eds. (New York: W.W. Norton \& Company, Inc., 1979) 258. 
symbolic presence of Urizen; this Zoa's overwhelming influence to the exclusion of the other three psychic aspects represented by Los, Luvah, and Tharmas indicates the entirely mental nature of the image in its constrictive aspect of opacity; this renders it unable to receive divine light. The absence of grounding features underscores the figures' artificiality, although they seem real for, as Harold Bloom observes "In the imagination, the most real thing is the imagination."66 The Flea, like Satan, is an actor, whom Blake directs pedagogically for his audience. He is a Spectre, which Northrop Frye defines in the following manner:
Abstract ideas are called spectres by Blake, and Spectre with a capital letter is the selfhood. The corresponding term is 'Emanation,' which means the total form of all the things a man loves and creates.

The performative natures of Flea and Satan, traditional to the pictorial Medieval story-telling devices of emblems and icons, is typical also of Gothic iconography. This is the traditional 'speaking picture' of iconography, which relies on emphasizing visual cues. Because of the centrality of this iconographic theme, it is worth

66 Harold Bloom, Wallace Stevens, Voices and Visions II, The Annenberg / CPB Collection, South Carolina Educational Network, The National Endowment for the Humanities and the Annenberg / CPB Foundation (Producer: New York Center for Visual History, 1988).

67 Northrop Frye, Fearful symmetry: A Study of William Blake (Princeton: Princeton University Press, 1974) 73. 
reiterating that Blake's plates are "like the visual presentation of melodrama, mime, or dance, forms which depend upon exaggerated bodily and facial gestures to make up for their lack of verbalization." 68 This method of dramatization is particularly striking in the grotesquely anthropomorphized Flea and the masked Satan. In the same vein of figures as performers, Kathleen Raine comments on the puppet-like quality of Satan in Satan in His Original Glory (Figure 7). Her response is arcanely turbid: "Blake has conveyed in his mask-like appearance... mere play upon the surface of ever-mysterious life."69 Raine's hermetic tone is counter to Blake's method; he strove to demystify life. Satan is an imaginative construct; like The Flea, he is unillumined within; but Satan is more treacherous than The Flea because, rather than its being a mere curtain that is deceptively gilt, Satan himself is beguilingly gorgeous on the exterior. His expressionless face typifies "the denatured mask that had come down through a thousand years [since Byzantine icons]." 10 Appropriately, there is no vortex dynamism nor penetrating eyes to symbolize cosmic

68 W.J.T. Mitchell, Blake's Composite Art: A Study of the Illuminated Poetry (Princeton: Princeton University Press, 1978) 29 .

69 Kathleen Raine, Blake and Antiquity, Bollingen Series XXXV: II (Princeton: Princeton University Press, 1977) 91.

10 Louise Gardner, Art through the Ages, 7th. ed. (New York: Harcourt Brace Jovanovich, Publishers, 1980) 333. 
vision in Satan in His Original Glory (Figure 7). His unseeing eyes signify the inward nature of the subconscious; Blake presents Satan as a state of error reflecting wrong intentions and perceptions like the lowest mineral soul expressed by Blake's unimaginative, mundane pebble:

But a pebble of the brook, Warbled out these metres meet: "Love seeketh only self to please, To bind another to its delight; Joys in another's loss of ease, And build a Hell in Heaven's despite." $" 1$

Blake also indicates Satan's militant mode with his maculated serpentine shoulder strap for a quiver of arrows or munitions; this is reminiscent of Milton's portrayal in Paradise Lost of the warring Satan, in whom "the mind is its own place" like the pebble's building a "Hell in Heaven's despite" with wrong, materialistic intentions. Blake uses specific iconography in his imagistic depiction of Satan:

The many-winged figure of Satan is depicted with his right foot forward to denote his earlier spiritual aspect, and with his head decked out with flowers. His outstretched hands hold an orb and sceptre, symbols of earthly dominion.

Blake's Satan anticipates an earthly kingdom as signified by his floral headdress, emblematic of postlapsarian nature's transiency traditionally symbolized in the carpe florem, and

11 William Blake, "The Clod \& the Pebble," Blake's Poetry and Designs, Mary Lynn Johnson and John E. Grant, eds. (New York: W.W. Norton \& Company, Inc., 1979) 43, I ines 7-12.

12 Raymond Lister, The Paintings of William Blake (Cambridge: Cambridge University Press, 1986) Plate 40. 
carpe diem themes; his sceptre and orb are significant of worldly state and church rulership. Satan offers no Heavenward gesture, for he is "prince of this world" (John xii:31; xiv:30; xvi:11) and "god of this world" (II Cor iv:4). Like Milton, Blake creates a disjuncture between idea and word. The idea of Lucifer as an admirable promethean contrasts with his unreality as a state of error. Although there is a copula of image portraying Satan as Lord of angels with his insignia of earthly rulership, gorgeous physique, and hieratic paraphernalia; and word indicating Satan's delusoriness for "In the Individual, Satan is the principle of selfishness (the selfhood) and the function of rationalizing (the Spectre)"13 and the Adversary; yet a chiasmus is triggered through paradox to illustrate that the image forms or frames the idea behind the mask's structured appearance. Satan is as the visionary imagination perceives him to be; his blank expression indicates his unreality apart from human imagination. This blank mask quality, which characterizes the visage of Lucifer in Satan in His Original Glory (Figure 7 ), makes his face vacuous to emphasize that "In Blake's view Satan was not a being, but a state of Error."14 He is the "Limit of Opacity" in The

73 S.Foster Damon, A Blake Dictionary: The Ideas and Symbols of William Blake, Rev. ed. (Hanover: University Press of New England, 1988) 356 .

74 Raymond Lister, The Paintings of William Blake (Cambridge: Cambridge University Press, 1986) Plate 40. 
Four Zoas (iv:27) which cannot receive divine light; so, despite Satan's golden surroundings in Satan in His Original Glory (Figure 7), the golden glow is superficial; it marks Urizen's domain as sun god in its rational, constrictive sense rather than Los's influence as sun god in its aspect of spiritual illumination. Harold Bloom likens Blake's Satan not only to Prometheus, but also to Phaeton:

Blake's Satan is a shadowy hermaphrodite because he embodies the self-congratulatory state of Ulro, the chaotic condition in which a brooding subject endeavours to contemplate all reality as being drawn up into itself.

As noted, the designs of Blake's other plates were affected profoundly by Gothic architecture and tomb statuary as well as Gothic iconic art. Since he was apprenticed to James Basire in the $1770 \mathrm{~s}$ to sketch the monuments in Westminster Abbey, ${ }^{76}$ Blake often climbed up to sketch the stone effigies from astride the Tomb statuary. This confrontational architectonic image recurs later in his depictions of the cramped posture and developed musculature of Urizen, the chained Orc, and the stony Elohim. The visage and looming quality of his Cherubim in Ezekiel's Wheels (Figure 1 ) and of Satan in Satan in His Original Glory (Figure 7), very different from the Oriental, more naturalistic cast to the visage of God Blessing the Seventh

75 Harold Bloom, Blake's Apocalypse (New York: Doubleday \& Company, Inc., 1963$) 258$.

76 Robert N. Essick and Donald Pearce, eds., Blake in His Time (Bloomington: Indiana University Press, 1978) 178. 
Day (Figure 5), are reminiscent of the sort of stone statuary once beneath Blake's feet in the Tombs; it is as if they had been raised up vis-à-vis Blake from the compressed horizontal plane to the vertical orientation of bas-relief. This kind of imagery as mimesis recurs throughout Blake's work.

The ultimate mimesis is visionary imagination, which shares certain characteristics with eidetic imagery. Typical of classic accounts of extreme eidetic phenomena, Blake claimed to be able imaginatively to move such mental images in space. While visionary imagination is nonmanipulable in three-dimensional space, it is arrestingly lucid and non-amorphous. This is consistent with Blake's insistence on the apparent visual definition of his perception of spirit forms; a luridly colored clarity also characterizes his stylistic model, the religious icon, as well as the surreal forms of his eidetic imagery. In this respect, Blake's eidetic imagery--an imaginative construct-is his visionary imagination, which he dramatizes throughout his humanistic icons. As indicated, to demonstrate the unifying power of imagination, Blake subverts the traditional method of reading images iconographically from Gothic icons; these were derivative of the Christian 
Byzantine iconostasis; ${ }^{11}$ while the church sanctuary implying spirit lay behind the iconostasis, the poesy revealing human essence lies behind Blake's icon, and divine spirit resides within the human form. As intense colors and strong forms characterize the iconostasis, to enable seeing clearly through incense smoke and dim candlelight, Blake's icons are surrealistically colored and precisely defined to facilitate vision that stimulates imagination capable of penetrating veils of literalism. His specialized colors and brilliance of light effects are conceptually integral, since, as George Herbert makes clear, "Doctrine and Iife, colours and light, in one / when they combine and mingle, bring / A strong regard and aw," 18 while words alone vanish like "a flaring thing." 19

Consistent with the principle of Blake's expression of unity of body and soul achieved through the transformative power of visionary imagination as inscribed in his complementary image and poesy, Mark Schorer observes that "Blake made no distinction between the visual and the

77 As previously stated, the iconostasis is a "large iconbearing screen that shuts off the sanctuary from the rest of the church.... to enable the worshiper to read pictorially," Louise Gardner, Art through the Ages, 7th. ed. (New York: Harcourt Brace Jovanovich, Inc., 1980) 251.

78 George Herbert, "The Windows," English SeventeenthCentury Verse, Louis L. Martz, ed., Vol. 1 (New York: W.W. Norton \& Company, Inc., 1973) 3:1-3, 163.

19 George Herbert, "The Windows," English SeventeenthCentury Verse, Louis L. Martz, ed., Vol. 1 (New York: W.W. Norton \& Company, Inc., 1973) 3:4, 163 . 
verbal." The anagogic content or intent in Blake's imagery is expressed by his iconography; as Schorer points out, this is typical of apocalyptic thinking:

Blake's habit of mind may be described, in the sense of $C$. E. Douglas, as apocalyptic, "thinking visually. The Apocalyptist thinks in pictures, not 'true' in themselves, 800 but indicative of the truth which lies behind."

This type of thinking in pictures is visual allegory. The eidetic image or vision (plate) represents the mask or container for idea or word (poesy); together they transform the viewer (reader) by depicting or stimulating visionary imagination. Adults who retain their common childhood tendency to eidetic imagery are mostly artists, usually visual artists but also poets and musicians. As mentioned, the images do not seem to be sui generis, but apparently arise spontaneously from the depths of the subconscious. Sir Herbert Read speculates about a correlation between eidetic imagery and the creative temperament; he says,

It may be that such eidetic individuals are more self-analytical than an eidetic person without creative gifts would be, but the theory has been put forward by Jaensch and others that such persons gre creative artists because they are eidetic.

Blake's contemporary, the Romantic poet Percy Bysshe Shelley described incidents which sound remarkably like episodes of

80 Mark Schorer, William Blake: The Politics of Vision (Gloucester: Peter Smith, 1975) 11

81 Sir Herbert Read, Education through Art (London: Faber and Faber, 1958) 41 . 
eidetic imagery. According to Medwin's Life of Shelley, the poet

could throw a veil over his eyes and find himself in a camera obscura, where all the features of a scene were reproduced in a form more pure and perfect than they had been originally presented to his external senses.

Shelley was known to experience hallucinations, but this does not preclude the possibility that he also experienced eidetic imagery. However, Shelley's reported experience was vivid recall of an "originally presented" scene as opposed to the creations of eidetic imagery, which seem to arise spontaneously from the depths of the unconscious. Accounts of such imagery are not exceptional among the other Romantic poets of Blake's era, notably those of Samuel Taylor Coleridge. What Sir Herbert Read cites that is unusual is Blake's ability apparently to summon the eidetic images at will. ${ }^{83}$ The peak times for Blake's willed imagery seemed to be between ten at night and two or four in the morning. It was during one of these ascribed episodes that he drew the "Head of a Flea"; this provided the study for his painting of The Ghost of a Flea (Figure 4). The most precise evidence for Blake's eidetic imagery is the description of this episode given by Varley, who says,

82 Medwin, Life of Shelley, Education through Art, Sir Herbert Read (London: Faber and Faber, 1958) 42 .

83 Sir Herbert Read, Education through Art (London: Faber and Faber, 1958) 43 . 
I felt convinced by his mode of proceeding that he had a real image before him, for he left off, and began on another part of the paper to make a separate drawing of the mouth of the Flea, which the spirit having opened, he was prevented proceeding ${ }_{84}$ ith the first sketch, till he had closed it.

This presumes that Blake experienced the eidetic image as a result of visionary imagination; that its orientation in three-dimensional space was perceived rather than its ascribed manipulability being Blake's hoax; that Varley's documentation was sound. Morton D. Paley provides additional insight into Blake's sketch of the Flea, which supports my view that this was not one of Blake's 'true' eidetic images. Paley says,

This is one of the celebrated 'Visionary Heads' produced for the artist and astrologer John Varley between 1819 and 1825. Keynes (Blake Studies, p. 134) has shown that in this instance Blake's vision was influenced ${ }_{85}$ by an engraving in Robert Hooke's Micrographia.

The drawing of the "Head of a Flea" might have been "influenced" by a seen work; it does lack the vividness and completeness typical of surrealistic art, which are characteristic of eidetic imagery. The absence of shadows also fails to suggest three-dimensionality; this flatness and linearity of the drawing are atypical of eidetic imagery; although the difference may lie in Blake's

84 Sir Herbert Read, Education through Art (London: Faber and Faber, 1958) 44 .

85 Morton D. Paley, william Blake (Oxford: Phaidon Press Limited, 1978) 181 . 
incompetent rendition rather than in his perception, it is more likely that Blake meant to exaggerate the focal form in a deliberate imitation of the Medieval tradition of basrelief or emblem; its linearity does suggest the type of contouring adopted by Albrecht Dürer, whom Blake admired, for his emblematic figures to emphasize the centrality of iconographical significance rather than representational veracity. Conversely, as previously noted, The Ghost of a Flea (Figure 6) manifests the luridly colored, precise, and three-dimensional quality associated with eidetic imagery. What distinguishes this eidetic ability from that of concentrated recall of memorized images is that it seems to come from the depths of the unconscious and to be projected and actually seen in the manner of visionary experiences. As mentioned, Mark Schorer compares Blake's visionary imagination to that of the Apocalyptist; while such 'seen' images are not intrinsically 'true,' they convey a profounder meaning deeper than language; like the ineffability of mystical experiences, their meaning is not readily susceptible to words, composed as they are of symbol, which Carl G. Jung claims is able to "express the inexpressible." Mark Schorer does not mention the term 'eidetic,' but his remarks about mental imagery in general provide insight into Blake's particular form of 'mindpicture' known as eidetic imagery:

The Apocalyptist thinks in pictures, not 'true' in themselves, but indicative of the truth which lies 
behind. The difference is that between ideas which come to the poet in the form of images and images in which the poet later discovers ideas. Intellect and sense are fused in both methods, but the control in the first is exercised by intellect, in the second by sense. The first method results in a relatively systematic arrangement of images within the poem, the second in a kaleidoscopic lack of arrangement, if it is a poem of any length. The second method is characteristic of $\mathrm{Blake.} \mathrm{His} \mathrm{ideas,} \mathrm{even} \mathrm{the}$ wonderfully generalized aphorisms, came to him as images; and his images on the other hand, are invariably symbolical.

Kaleidoscopic images or not, Blake composed a complex matrix of fourfoldness to which his visions conform. They articulate Blake's intricate cosmology of the visionary imagination. The integration of these four qualities becomes the "Human Form Divine" of "The Divine Image"; this is the spirit's working structure literalized in the human figure as the focal point which recurs throughout Blake's iconic plates. The human form obviously infused with spirit is most pronounced in the figures of Jesus in Christ Blessing (Figure 3), of Albion in Glad Day (Figure 4), and of Adam in Adam Naming the Beasts (Figure 2). Blake's Jesus and Albion, together with his Los, are aspects of the divine Man. Since, as observed, Los represents imagination, all humanity is included in this "Divine Appearance"; recognition of this inner divinity comes through the visionary imagination. Blake makes this revelation available to the informed interpreter of his twin creations

86 Mark Schorer, William Blake: The Politics of Vision (Gloucester: Peter Smith, 1975) 11 
of art (image) and poesy (word) as figures for incarnate

(body) spirit (soul). Accordingly, to understand these

three iconic plates, it is necessary to know something of

Blake's Jerusalem:

Then Jesus appeared, standing by Albion as the good Shepherd / By the lost Sheep that he hath found, \& Albion knew that it / Was the Lord, the Universal Humanity.... / And the Divine Appearance was the likeness and similitude of Los.

As initiated in Jerusalem and developed in The Four Zoas,

Blake's iconography is thus encoded according to his

controlling metaphor of the Four Zoas and should be decoded

according to his idiosyncratic artistic criteria. ${ }^{88}$

Blake's method imagistically is similar to his linguistic

patterning. Like a metaphysical conceit, Blake intends the

ambiguous image to be interpreted symbolically:

The sublimity of Blake's allegory...depends

87 William Blake, Jerusalem: The Emanation of the Giant Albion Plate 96, lines 3-7, Blake's Poetry and Designs, Mary Lynn Johnson and Mark E. Grant, eds. (New York: W.W. Norton \& Company, Inc., 1979) 354 .

88 Ernest Jones contends that the creations of poets "cast in ideational form" may be analyzed more readily than other art forms. While the cognitive process of a writer may be extrapolated from his linguistic production by literary critics, the image presented by a visual artist requires a different specialized language as well as intuition for its interpretation. Dramatic art has the special feature that fictive personae may reflect the author's psychological bias and represent reworked human prototypes. Hamlet and Oedipus, (New York: W.W. Norton \& Company, 1976) 15. According to Robin May Schott, when imagination and feeling cohere with structures imposed by the understanding (Kantean categorical thinking), the result is subjective reification. Cognition and Eros: A Critique of the Kantean Paradigm, (Boston: Beacon Press, 1988) 156 . 
ultimately on what is signified (transcendental truths) and who is addressed (true believers) and posits a triadic structure (sign, referent, recipient) based in turn on the community of speaker, audience, and the medium joining them. ${ }^{89}$

Blake as painter beckons his viewer through the image; his didactic intent is obvious in his use of the iconic form, traditionally a meditational device; he melds image and word, as counterparts to unified body and soul, by stimulating imagination; he does this most prominently in Adam Naming the Beasts (Figure 2), Christ Blessing (Figure 3 ), and The Black Madonna. While earlier Medieval designs affected his illustrations, ${ }^{90}$ the organic fluidity of some of the later High Gothic ornamentation, embedded in Blake's memory, also informs the iconography of his plates. ${ }^{91}$ The primary figure in his art, however, is the same as the central form in Gothic iconography; it is central to his primary literary sources of the Bible, Ovid's Metamorphoses,

89 Nelson Hilton's Review of William Blake and the Language of Adam, Robert N. Essick, Blake: An Illustrated Quarterly, Morris Eaves and Morton D. Paley, eds., vol. 23, no. 23, Fall, 1990 (Rochester: University of Rochester, 1990) 70 .

90 Edward Carpenter, ed., A House of Kings: The official History of Westminster Abbey (New York: The John Day Company, 1966) 8 .

91 In Hamlet and Oedipus, Ernest Jones points out that "An artist has an unconscious mind as well as a conscious one, and his imagination springs at least as fully from the former as from the latter," (New York: W.W. Norton \& Company, 1976) 19. 
and the Prose Edda; ${ }^{92}$ characteristically, it is the human

form which is paramount in Blake's iconic plates:

The concrete symbol or icon of the imagination in Blake's pictures is, of course, the human body. The nonillusionistic, stylized character of the settings which surround the body is Blake's iconographic way of restating his central premise, that the shape and significance of spatial reality is not objective or given, but derives its form and meaning from the human consciousness that inhabits it.

It is the visionary imagination which projects its Gestalt on to the world as fourfold. The stylization of the sets which Blake designs for his actors indicates their symbolic nature, like the deliberate flatness of the Gothic frieze, tapestry, and icon. His three color plates of 1810-1825

Adam Naming the Beasts (Figure 2), The Black Madonna, and Christ Blessing (Figure 3 ), by presenting the human form full-face and upper torso in the stylized, symmetrical pose typical of Byzantine and Medieval religious icons focusses attention in the manner of a Gothic meditational device, whereby intuition is led to apprehension of spirit. Contrary to orthodoxy's emphasis on the need for an intermediary, and standard Byzantine and Gothic icons' hieratic posturings which place divinity beyond human reach, Blake's humanized icons indicate that spiritual

92 Northrop Frye, Fearful Symmetry: A Study of William Blake (Princeton: Princeton University Press, 1974) 72 .

93 W.J.T. Mitchell, Blake's Composite Art: A study of the Illuminated Poetry (Princeton: Princeton University Press, $1978) 38$. 
transformation is possible and ubiquitously available through the unifying power of visionary imagination. The naturalistic cast of these humanized icons adumbrates High and Late Gothic's anticipation of Romanticism's extolling of vibrant individuality as expression of spirit. For Blake, passion and desire represent spiritual heat, and sexual love allows entrance to the imaginative realm. ${ }^{94}$

In his earlier series of 1800-1805, Blake depicts the old Testament figures of Elohim, Ezekiel, and Lucifer as full figures. Their treatment is typical of the attenuated figures and iconographical significances of Gothic art; this is apparent in God Blessing the Seventh Day (Figure 5), Ezekiel's wheels (Figure 1), and Satan in His Original Glory (Figure 7). The vivid, almost surreal quality of these icons is consistent with the intensity of Blake's eidetic imagery, while their fourfold iconographic meaning he typically indicates with color, proportion, and specific visual symbols. The four senses, corresponding to the four elements and cardinal compass directions in Blake's symbology, are represented by the implied presence of the four Zoas not only as color motifs but sometimes as actual humanized heads. Although the plates are intended to be read in light of the biblical fourfold exegetic method, it is as interpreted in Blake's "diabolical" sense to emphasize

94 Northrop Frye, Fearful symmetry: A Study of William Blake (Princeton: Princeton University Press, 1974) 73 . 
that their complementary "tension of opposites" is integrated through the visionary imagination.

Visually in the plates, the figurative human form either bisects or lowers over Blake's plates, reminiscent of a haloed prophet looming from a Gothic cathedral's stained glass as in The Ancient of Days or in Ezekiel's Wheels (Figure 1). But the form is enlivened with the surreal vivacity of eidetic imagery to underscore that it contains individualized spirit recognized by insight and dramatized through recurrent symbols for visionary imagination. The experience of spirit is no longer the domain of the prophetpriest-king; Blake proselytizes Protestantism's emphasis on the possibility of a personal spiritual relationship with Christ. Through the unifying power of visionary imagination, this is acknowledged as an inner divinity and man is transformed by his recognition of, and attunement with, his own essence.

Although to portray this Romantic interpretation of Christ, Blake systematically appropriates biblical iconography, he refuses to be enslaved by it; consequently he unhesitatingly distorts it. As Donna S. Rix points out:

Blake's way [was] of inverting and transforming images, themes, and especially characters to express his own complex and unorthodox vision. Even though Blake's thinking is firmly rooted in the biblical prophetic tradition in general, and (for Milton), in Second Isaiah in particular, he is far from being a slavish expositor of ancient prophecy. However deeply he draws on the biblical tradition, his relationship to it is 
curiously ambivalent. He draws on it for forms, patterns, themes, and images; yet he freely inverts, transforms, and rearranges the very elements that he borrows. Through his highly individualistic interpretation and arrangement of biblical material, Blake molds the old traditions into new forms of his own choice, sometimes with an accompanying vigion that is alien to the original material.

Iconoclastically, Blake deliberately distorts and rearranges not only bibical but other symbolism as he opposes alchemy to science in order to startle his audience into awareness. He insists that his interpreters surrender to metanoia:

Blake is an ironist who employs traditional poetic forms and formulas while frustrating the expectations they traditionally invite; the result is an attack on "the reader's easy acquiescence in the canons of the tradition from which both the forms and the language have been derived."

This is why his The Ancient of Days geometer-god is so misunderstood when unrecognized as ironic. As mentioned, Blake's focus on iconography in his plates, which demonstrates the written word's literalization into its counterpart, the visual image, reflects the Medieval convention of emblems and icons; it is influenced also by seventeenth century Christian philosophy. As William Vaughan reminds us:

95 Donna S. Rix, "Milton: Blake's Reading of Second Isaiah," Poetic Prophecy in Western Literature, Jan Wojcik and Raymond-Jean Frontain, eds. (Cranbury, New Jersey: Associated University Presses, Inc., 1984) 106.

96 Stephen D. Cox, "Recent Work on Blake," EighteenthCentury Studies, Max Byrd, Robert Hopkins, Arthur McGuinness, eds. vol. 18, no. 3, Spring, 1985 (Northfield: AMSD Press, Inc., 1985) 393 . 
Blake was heir to the Neo-Platonic notion that pictorial images were an essential means of communicating the ideal. He believed that they provided insights gqual, if not superior, in value to those of words.

According to S. Foster Damon, Blake's knowledge of Plato's philosophy of an ideal realm of Forms, intuited through the imagination, came from his reading of Paracelsus:

The imagination operates through man's spiritual body, which dominates his physical body. In Paracelsus his Archidoxes (London, 1661), Blake read: "The imagination is the sun of man.... Even as man imagines himself to be, sych he is, and he is also that which he imagines."

This is a perfect articulation of Blake's philosophy of the supremacy of the imagination; he expects his audience to exercise intuition in order to understand his art, since mere logic is inadequate to the task. To this end, Blake uses both image and word as complements in a systematic, syncretistic communication in his "unobtrusive dethronement of reason." It is to achieve this metaphysical communication that he manipulates High and Late Gothic influences, together with eidetic imagery, to present his unique iconographic art. ${ }^{99}$ This is not merely an act of 1984) 3 .

97 William Vaughan, William Blake (London: Bracken Books,

98 S. Foster Damon, A Blake Dictionary: The Ideas and Symbols of William Blake, Rev. ed. (Hanover: University Press of New England, 1988) 322 .

99 Sigmund Freud postulates that "A strong experience in the present awakens in the creative writer a memory of an earlier experience (usually belonging to his childhood) from which there now proceeds a wish which finds its fulfillment in 
mimesis; ${ }^{100}$ it represents the focus of a tacit ideational communion between artist (poet) and viewer (reader) through the mediation not of a priest-king, but that of intuition stimulated by Blake's dramatization of visionary imagination.

As this study shows, the combination of eidetic imagery and Gothic iconic influences in Blake's plates informs his dramatization of visionary imagination as the unifying principle between image and word as figurative body and soul; this emphasis on personal transcendence illustrates Blake's humanistic philosophy of inner divinity. The Medieval system of iconography that Blake adapts in order to do this is worth examining in some detail at this point in order to facilitate a more precise exploration of the next section on visionary imagination, as well as the ensuing three plates in the final section portraying Adam, Jesus, and Albion. In traditional terms, the ascending biblical exegetical hierarchy that Blake appropriates is from the literal or historic to the tropological or moral; to the allegoric; and finally to the anagogic:

the creative work. The work itself exhibits elements of the recent provoking occasion as well as of the old memory" (Der Wahn und die Tráume in W. Jensen's Gradiva, 1907; "Der Dichter und das Phantasieren," New Revue, 1908, Nr. 10, S. 716; Eine Kindheitserinnerung des Leonardo da Vinci, 1910; "Das Motiv der KÄtchenwahl," Imago, 1913, S. 257).

100 Erich Auerbach, Mimesis: The Representation of Reality in Western Literature (New York: Doubleday Anchor Books, Doubleday \& Company, Inc., 1957). 
the anagogical--as the name implies--foreshadowed the myffery of a future life and eternal

bliss.

This definition implies the visionary realm which

traditionally has been apprehended through the higher mental faculty of intuition. Blake subverts this system to emphasize the possibility of divinity's immanence through visionary imagination in contradistinction to the Medieval belief in the ultimate reality of a 'higher' spiritual realm. This emphasis on present joy rather than on a "future life" is reflected in the quality of Blake's visual and poetic imagery; these are distilled in the least traditionally iconic work among his plates, Glad Day (Figure 4), which is a production executed under Roman influence. It is included in the study because it is the most perfect illustration of Blake's philosophy of fulfilled humanity, reminiscent of Aristotle's eudaimonia, transformed by visionary imagination into its Higher Innocence as signalled by joyous spontaneity. Glad Day (Figure 4) represents the culmination of the preceding phases depicted by Adam and Jesus; Albion's ecstatic gesture indicates utter openness of spirit congruent with his total nakedness of body. It is the perfect illustration of Blake's theory of Vision provided in his "Eternity":

$$
\text { He who binds to himself a joy }
$$

101 Emile Mäle, The Gothic Image, Dora Nussey, transl. (New York: Harper \& Row, Publishers, Icon Edition, 1958) 139. 
Does the winged life destroy

But he who kisses it as it flifes

Lives in eternity's sun rise

Blake invites the viewer (reader) into this transformative experience by stimulating intuition with his dramatization of spirit's ubiquitous availability through the power of visionary imagination. A tacit dialectic is initiated between Blake and audience through the medium of the painting in the tradition of icon as communion between painter, viewer, and spirit mediated by intuition. As Nelson Hilton realizes:

Blake's works [present] a kind of paradigm shift from structuralism (and post-) to phenomenology; that is, from "dyadic signification (signifier/signified) to triadic interchanges among authpr [painter], text [plate], and reader [viewer].

The "paradigm shift from structuralism...to phenomenology" invokes literalization of the linguistic statement through imagination to draw the viewer into Blake's imagistic frame of reference. As already related, Blake's phenomenology (image) embodies his ontology (poesy) primarily from the Bible, as well as from Ovid's Metamorphoses, and, according to Northrop Frye, the Prose Edda, by focussing on the human

102 William Blake, III. Vision, "Eternity," lines 1-4, Blake's Poetry and Designs, Mary Lynn Johnson and Mark E. Grant, eds. (New York: W.W. Norton \& Company, 1979) 183.

103 Nelson Hilton, Review of William Blake and the Language of Adam, Robert N. Essick, Blake: An Illustrated Quarterly, Morris Eaves and Morton D. Paley, eds., vol. 23, no. 23, Fall, 1990 (Rochester: University of Rochester, 1990) 67 . 
form. Although his method to stimulate an interchange between image and viewer is typical of traditional iconic art, Blake demonstrates that the spiritual state is inner. As previously observed, he believes in a Platonic uncreate, indestructible personal esse. ${ }^{104}$

Since realistic mimetic art concentrates on the literal, it is inconsequential to Blake, while Gothic's "living form" contributes the appropriate vehicle. Blake's antagonism toward representational art's lack of uniqueness in irregularities and organic decoration characteristic of Gothic's "living form," as well as its iconographical content, is reiterated throughout his work. He vehemently denounced formulaic codification, as exemplified by mechanistic physics. Kathleen Raine reminds us that the three English philosophers associated particularly with sceptical rationalism formed the butt for Blake's attack:

Bacon, Newton, and Locke are but the names under which he denounced the scientific philosophy which still continues to dominate the modern West. When in 1808 he annotated, with devastating comments, his copy of Reynolds' Discourses on Painting, he recalled that when young he had read Burke's treatise which "is founded on the Opinions of

104 The essence is soul, which Plato believed indestructible: "All soul is immortal; for what is always in motion to something else, even though it is itself the cause of motion in another thing, may cease to be in motion and therefor cease to live. Only what moves itself never ceases to be in motion, since it could not so cease without being false to its own nature; it is the source and prime origin of movement in all other things that move," Phaedrus and Letters VII and VIII, trans. Walter Hamilton, Rpt. (New York: Penguin Books, Viking Penguin Inc., 1988) 49. 
Newton... [and] felt the Same Contempt \& Abhorrence then that I do now. They mock Inspiration and Vision."

As indicated, Blake uses alchemy and the spatial-temporal sense of the four zones or states to oppose science. The prophetic tradition of the Hebrews attracts him, with its reverence for visionary imagination, for this reason also. Kathleen Raine observes that this contributed to Blake's equation of Jesus with imagination:

The traditional doctrine of an indwelling divine mind Blake knew in many versions besides the Platonic.... Jones actually points out the resemblance of the $H$ indu philosophy that sees all phenomena as maya, a system of appearances whose reality is only in mind, to the philosophy of Berkeley. Blake too considered the Divine Imagination to be present in all men--indeed in all creatures. It is because the Jewish tradition is supremely prophetic and imaginative (as against the rational thought of Greece) that Blake sees the "jews' [sic] god" as finally triumphant; for the indwelling imagination that spoke by the prophets is at last manifested as "the divine Humanity, Jesus the Imagination." 106

Blake expresses his persistent, fundamental belief in the primacy of the imagination over the constrictions of pragmatic logic and mechanistic physics in his visionary Ezekiel's Wheels (Figure 1), which Northrop Frye contends is the symbol of Blake's cosmology, for "it is a revolutionary vision of the universe transformed by the creative

105 Kathleen Raine, Blake and Antiquity (Princeton: Princeton University Press, 1977) 88 .

106 Kathleen Raine, Blake and Antiquity (Princeton: Princeton University Press, 1977) 89. 
imagination into a human shape."10? The macrocosm of the universe is reiterated in the microcosm of the Cherubim of Ezekiel's Wheels (Figure 1), which is reiterated through the lesser microcosm of the overwhelmed prophet. Inferentially, it reverberates on down through the Great Chain of Being to the most infinitesimal level in the dance of life within its net of correspondences; the critical distinction in Blake's reinterpretation is that he sees this as an egalitarian, organic process as opposed to a hierarchical structure. It is, as W.B. Yeats expresses, that interconnected play of the parts, which cumulatively express vibrant life itself infused with spirit:

O chestnut tree, great rooted blossomer, Are you the leaf, the blossom or the bole? $O$ body swayed to music, $O$ brightening glanfe, How can we know the dancer from the dance?

The culminating visual expression of this principle of the dance of life is Blake's mythopoeic vision of unified man in Glad Day (Figure 4); although executed earlier than the biblical series, this plate shows through its alternate title the ecstatic Dance of Albion (Figure 4) that it represents also the liberated political state. Albion is

101 Northrop Frye, Fearful Symmetry: A Study of William Blake, 4th. ed. (Princeton: Princeton University Press, 1974) 5 .

108 w.B. Yeats, "Among School Children," VIII: 61-4, The Tower, The Collected Poems of W.B. Yeats, Richard J. Finneran, ed., New ed. (New York: Collier Books, Macmillan Publishing Company, 1989) 217. 
the imaginatively integrated human, symbolic of the microcosm within the free political state of the macrocosm; his dance is the dance of life as an apotheosis of Blake's vision of the integration of the four Zoas in the "Human Form Divine." This is Blake's articulation of what Wallace Stevens refers to as the anthropocentric "rage for order," which Blake expresses epigrammatically in one of his preeminently gnomic stanzas in his ironically titled "Auguries of Innocence":

To see a World in a Grain of Sand And Heaven in a Wild Flower:

Hold Infinity in the palpg of your hand And Eternity in an hour.

Blake presents and represents this Romantic principle of microcosm within macrocosm through recursive images which insist on vision and revision for their interpretation and reinterpretation. In this way, Blake develops his viewer's visionary imagination while dramatizing his own. As one of Blake's most lucidly potent single portrayals of this reciprocal action of visionary imagination as communion between painter and viewer, his cosmic Cherubim in Ezekiel's Wheels (Figure 1), provides a basic reference point throughout this study.

In Ezekiel's Wheels (Figure 1), Ezekiel's vision of the Cherubim is four-faced to correspond with Blake's system of

109 William Blake, "Auguries of Innocence," The Pickering Manuscript, lines 1-4, Blake's Poetry and Designs, Mary Lynn Johnson and Mark E. Grant, eds. (New York: W.W. Norton \& Company, Inc., 1979) 209. 
four Zoas as expressions both of the four primary states of the human condition and of man's four levels of cosmic perception. Consistent with his elevation of the importance of imagination, Blake considers painting, poetry, and music to be "the three Powers in Man of conversing with Paradise."110 It is in this way that he uses his twin media of plates and poesy; the image lucidly demonstrates his idea as its soul. Blake intends his art to liberate humanity from self-imposed and socially mandated or sanctioned bondage into spiritual freedom; he does this by dramatizing the potentially transformative and integrative power of visionary imagination through the harmonious blending of visual image (body) with poetic word (soul) to reveal his humanistic belief in inner divinity or esse. 111 He rivets attention in the manner achieved by the monumental images of Gothic iconography combined with the surreal vividness of eidetic imagery, while softening the

110 S. Foster Damon, A Blake Dictionary: The Ideas and Symbols of William Blake, Rev. ed. (Hanover: University Press of New England, 1988) 318 .

111 The idea of an indestructible, uncreate soul derives from Plato: "In the Phaedrus it is argued that a thing which moves another, and is moved by another, may cease to live as it may cease to be moved. The soul, however, is a self-moving principle, a source and beginning of motion, and that which is a beginning must be uncreated, for if it were not uncreated, it would not be a beginning. But if uncreated, then indestructible, for if soul, the beginning of motion were destroyed, all the universe and creation would 'collapse and come to a standstill." Frederick Copleston, S.J., A History of Philosophy, Volume I: Greece and Rome (New York: An Image Book, Doubleday, 1985) 214 . 
static, structural form with High Gothic's more naturalistic figures and organic decoration. The eye motif, symbolic of visionary imagination, becomes conflated with the representation of the physical eye in Rlake's iconic human forms. Simultaneously, this indicates his creative identification with the figure's generation of ideas into shapes, as name and image named demonstrably become identical in Adam Naming the Beasts (Figure 2), and engages the viewer in a communion which begs self-appraisal; the stylization of the background signifies its artifice as a mental construct of the central focal human form in the plate. The result is personal apprehension of inner divinity and potential creativity through individual visionary imagination. Blake's combination of eidetic clarity and High Gothic naturalism finds resonances within the psyche of the receptive viewer. This privileges other artists who retain eidetic ability, since a resonating chord is struck within them. The advantage is conferred by their sensitivity to visionary imagination.

Blake's specialized use of red and gold tones in the plates conveys iconographical meanings derived from various disciplines; he does this deliberately to demonstrate that each philosophy represents an attempt to express the same essential truth; that the system should not be inferred as the revelation but as a means to a deeper truth. He distills this truth in his plates through the insinuated 
presence of his Zoas as hues of the three primary colors.

\section{BLAKE'S ICONOGRAPHY OF VISIONARY IMAGINATION}

To reiterate my thesis in broad terms before exploring in more detail Blake's use of motifs to dramatize the visionary imagination: In his dramatization of visionary imagination through image as body and word as soul, Blake's focus on the human form is consistent with his humanistic philosophy. His source for the plates' fundamental theme was "Vision" or Imagination; he was able to transcribe this because "He had an astounding power of visualizing, which went far beyond the power of seeing with the mind's eye."112 In this section, I shall examine indications in the eight plates of this special way of 'seeing' involving eidetic imagery, which confers the surreal vividness and discreteness associated with visionary experience as distinct from the amorphousness of inchoate ideas. I intend to show that Blake's visionary imagination penetrates veils of nebulousness to reveal surreal forms enhanced by intense color hues in the manner of the iconostasis' exaggeration of shapes and colors. While the iconostasis was designed to retain visual clarity literally through the incense haze and dim candlelight, it also meant to activate allegorical

112 S. Foster Damon, A Blake Dictionary: The Ideas and Symbols of William Blake, Rev. ed. (Hanover: University Press of New England, 1979) 318 . 
perception. Blake's intent is likewise to transform sight to insight by penetrating veils of materialism. His central theme of the human form to dramatize imagination also reflects his distrust for mechanism and pragmatism. This contempt ior codification is symbolized by the geometer's compasses in Newton (Figure 8) and the cogs in Ezekiel's Wheels (Figure 1). That he opposes mechanistic physics with his visionary imagination, using these particular symbols is revealed in Jerusalem:

...many wheels I view, wheel without wheel, with cogs tyrannic / Moving by compulsion each other: not as those in Eden: which / wheel withjn wheel in freedom revolve, in harmony \& peace.

Blake contrasts Ezekiel's Vision of angelic wheels (Ezekiel $1: 16)$ with mechanical cogs and wheels. Traditionally, the eye has symbolized insight, or what Blake distinguishes as "seeing through" appearances as opposed to seeing mechanically with the physical eye. He emphatically does not believe that spirit is diffuse, since his visionary imagination presents ideas with vivid clarity within his imaginatively projected reality. Rather, the apprehension of spirit involves a different manner of perception from the mechanical process of sight which results in literal vision; being distinct from phenomenology, it becomes the domain of

113 William Blake, Jerusalem: The Emanation of the Giant Albion, Plate 15, lines 18-20, Blake's Poetry and Designs, Mary Lynn Johnson and John E. Grant, eds. (New York: W.W. Norton \& Company, Inc., 1979) 319. 


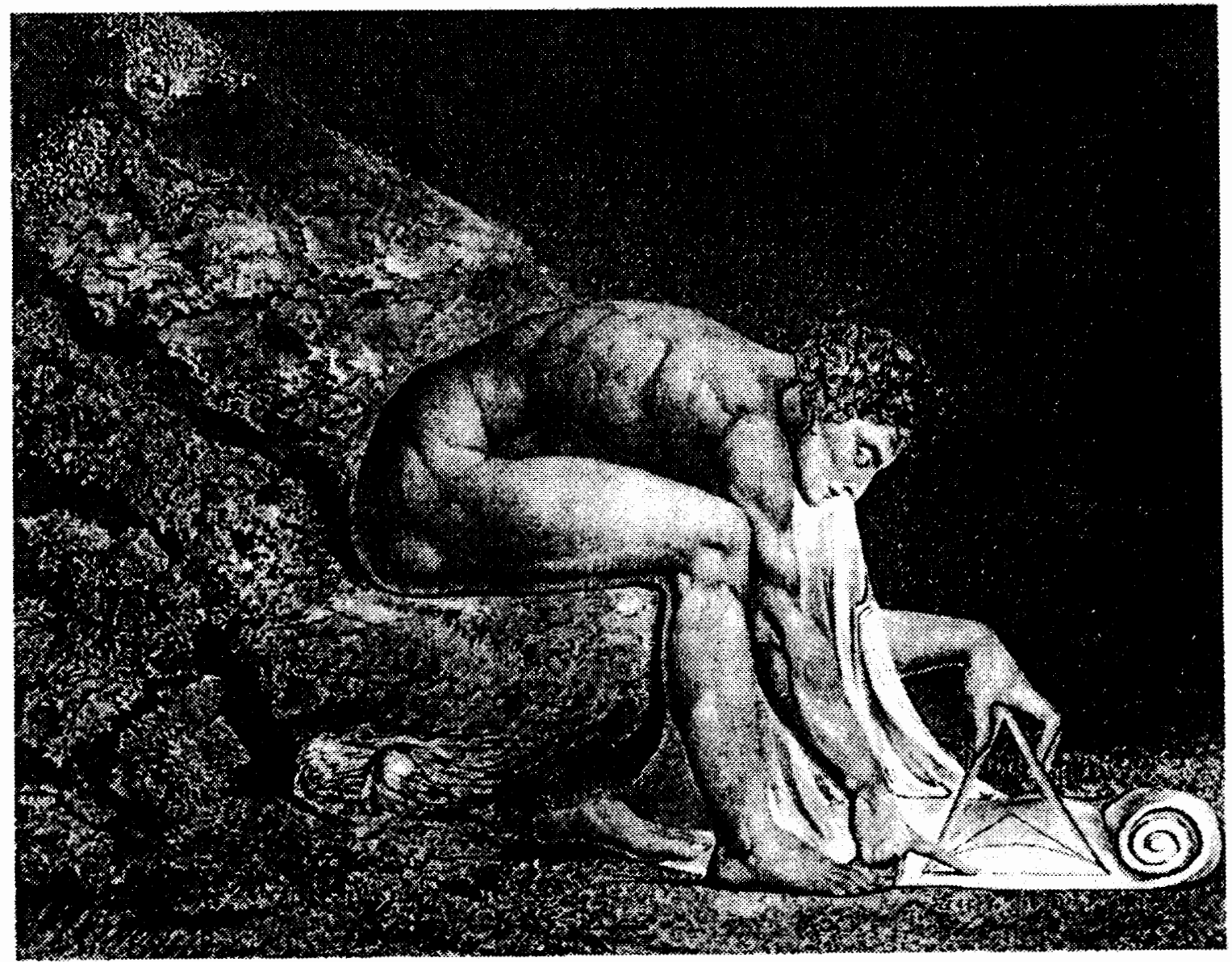

Figure 8. Newton. 
allegory. As Blake explains,

"A Spirit and a Vision are not, as the modern philosophy supposes, a cloudy vapour, or a nothing: they are organized and minutely articulated beyond all that the mortal and perishing nature can produce. He who does not imagine in stronger and better lineaments, and in stronger and better light than his perishing and mortal eye can see, does not imagine at all. The painter of this work asserts that all imaginations appear to him infinitely more perfect and more minutely organized than any thing seen by his mortal eye" (DesC IV,K 576).

Eyes as Symbols

As indicated several times previously, Blake's emphasis on vision is symbolized with recurrent eye motifs in Blake's plates; this, together with vortex-wheels of energy, is integral to Blake's iconography of visionary imagination. There is a cyclic development to his patterns of eye symbolism in Blake's iconography of visionary imagination, which he dramatizes in the plates. Beginning with the compression possible with synecdoche to indicate a single entity such as the tiger eye to imply an entire creature, suitable for his small illuminated manuscripts, Blake develops this use of metaphor to expanded usage to represent dual levels of perception in his larger illustrations, such as the implied authorial eye in Visions of the Daughters of Albion. As the scope of his painting broadens to accomodate

114 S. Foster Damon, A Blake Dictionary: The Ideas and Symbols of William Blake, Rev. ed. (Hanover: University Press of New England, 1988) 318 . 
his exfoliating vision, Blake employs recursive series of synecdochal patterns in his plates to encompass cosmic illumination with multiples of swirling eyes, as in Ezekiel's Wheels (Figure 1). Finally, this device to indicate cosmic illumination mutates to express insight or intuition of inner divinity; accordingly, the cosmic eye motif becomes conflated with the human eye, such as that of Adam in Adam Naming the Beasts (Figure 2) and of Jesus in Christ Blessing (Figure 3). Blake systematically dramatizes the multiplicity of spirit's manifestations --or, rather, perception's interpretative vagaries--with these recurrent motifs of eyes as well as vortices. To illustrate the dynamic tension of oppositions which converge on the apex at the interface of vortices toward the womb of eternity, Blake combines eye and vortex symbolism in Ezekiel's Wheels (Figure 1). His Zoas express this dichotomy between paired antimonious aspects of the psyche, which contain the potential for complementarity; the Zoa-Cherubim illustrates the unification of body and spirit as he stands at the central still point between chthonic (serpent:body) and ethereal (wings:spirit) elements; visionary imagination effects the transformation. The central axis of Cherubim's body is transcended by the vortex-wings of spirit.

Blake's progressive series of eye symbolism follows a developmental sequence; the single eye motif for the illuminated manuscripts marks the beginning of his cyclic 
pattern. As seen in the symbolic imagery of his paired poems for songs of Innocence and of Experience, he begins with the single eye motif as synecdoche in "The Tyger" to express a particular quality:

Poetry, of course, must express beauty. The poet, therefore, must strive to render this transcendent truth in sensuous form, to translate his conception into an image which shall serve as a key or symbol, just as the luminous eye of the tiger symbolizes the whole tiger in a dark jungle.

Blake uses the poetic synecdoche of "luminous eye" to characterize his entire tiger in "The Tyger"; this type of eye motif as a symbol for spiritual illumination is integral and recurrent in $B l a k e ' s$ plates. In his frontispiece to Visions of the Daughters of Albion, the golden orb of the sun is a visual synecdoche for the authorial anguished stare at his own depiction of the Zoa Urizen's influence of stasis on Bromion, Theotormon, and Oothoön:

Dominating the sky and background of the plate is a form that might be the sun shining through an opening in the clouds, but that looks to most viewers like a large eye ("Instead of morn arises a bright shadow, like an eye in the eastern cloud" [2:35-46]).

115 Ralph Crum, "Poetry Solemnly Surveys the Newtonian World Machine," Science and Literature, John J. Cadden and Patrick $R$ Brostowin, eds. (Boston: D.C. Heath and Company, 1964) 112 .

116 Thomas A. Vogler, "'In vain the Eloquent tongue': An Un-Reading of VISIONS of the Daughters of Albion," Critical Paths: Blake and the Argument of Method, Dan Miller, Mark Bracher, and Donald Ault, eds. (Durham: Duke University Press, 1987) 286. 
Similarly, in The Body of Abel Found by Adam and Eve, the synecdochal eye is the red orb, insinuating Los's presence as imagination, like an angry sun glowering over the murder scene. A red mark is on Cain's forehead, indicative of the literalized consequence, since "And the Lord set a mark upon Cain" (Genesis IV:15); Blake implies that Cain's curse actually is tormenting memory augmented by imagination, which perpetually relives anguish and excoriates his guilty conscience; this emphasis on imagination is crucial to Blake's philosophy, since "imagination--and here was Paracelsus' great discovery--is the central function of man and the source of all his activities."11?

Blake's depiction of The Tyger's "fearful symmetry" reflects traditional idealism which "must express beauty" because its impulse is to reveal truth; that this can be transmitted only through sensible symbols is an axiomatic principle exploited by Plato, by Gothic iconography, and by neo-Platonism. However, it is the ambiguity of the meaning of Blake's "The Tyger" that typifies his special metaphysical method. "The Tyger" seems infernal and is contrasted in Songs of Experience with "The Lamb" in Songs of Innocence. This argues that it is the alternate mask of the same reality, as anger and benevolence are alternate human states. The fierceness of the Tyger as God's wrath is

117 S. Foster Damon, A Blake Dictionary, 322. 
congruent with that character of Jesus who banished the money-lenders from the temple as a metaphor for the harrowing of avarice and usury from the human psyche; this predatory image, aspect of gluttony, is expressed in Blake's plate, The Ghost of a Flea (Figure 6), showing the Flea gloating over his bowl of blood. The "luminous eye of the tiger" represents the light generated by the flames, metonymically represented by the tiger striations, of visionary imagination as opposed to God's love or Blake's "creeping Jesus" expressed by the Lamb. Michael J. Tolley observes only one face, while K.D. Sethna sees only its antithesis in "The Tyger"; "he [K.D. Sethna] sees Christ in the tyger figure where $I$ see falling Lucifer, fallen as a form of Satan."118 Blake intends an oxymoronic congruence between the Tyger and the Lamb to reveal the paradox of "intellectual conflict" which signals the opening through corresponding vortices from temporal-spatial time into eternity. But understanding this involves visionary imagination

As indicated by Rachel V. Billigheimer, ${ }^{119}$ the eyes of

118 Michael J. Tolley, Review of Blake's Tyger: A Christological Approach (Pondicherry: Sri Aurobindo Ashram Press, 1989) in Blake: An Illustrated Quarterly, Morris Eaves and Morton D. Paley, eds., Fall, 1991 (Rochester: University of Rochester, 1991) 89 .

119 Rachel V. Billigheimer, "Blake's 'Eyes of God': Cycles to Apocalypse and Redemption," Philological Quarterly, William Kupersmith, ed. vol. 66, no. 2, Spring, 1987 (Iowa City: The University of Iowa, 1987) 231 . 
God symbolism in such work as Ezekiel's Wheels (Figure 1) represents the incremental imaginative development in the individual away from the literal toward the visionary.

David Sten Herrstrom believes that Blake identifies Ezekiel's Cherubim "with aesthetic and moral wholeness, the 'Human Form Divine' and 'Holy Brotherhood." 120 Blake emphasizes the polarity between literalism and imagination in Ezekiel's Wheels (Figure 1), and Satan in His Original Glory (Figure 7) to focus on inner spirit within body or a psychic state which needs to be acknowledged. In his depiction of the Cherubim, Blake symbolizes developmental stages with wheels and spiritual illumination with eyes to dramatize exfoliating, incrementally more competent visionary imagination. But the temporal-spatial realm is integrated into his symbolism as it takes on literal implications by portraying eyes placed within mechanical cogs. As Rachel V. Billigheimer says,

Erdman observes that the mechanical wheel which is blindly driven is opposed to the eyed wheel of Ezekiel's vision whose center is God and whose cogs are eyes. He states that where the first six eyes have failed, the seventh completes revolution and delivers man from suffering.

120 David Sten Herrstrom, "Blake's Transformations of Ezekiel's Cherubim Vision in Jerusalem," Blake: An Illustrated Quarterly, Morris Eaves and Morton D. Paley, eds. vol.15, no. 2, Fall, 1981 (Berkeley: University of California, 1981) 64 .

121 Rachel V. Billigheimer, "Blake's 'Eyes of God': Cycles to Apocalypse and Redemption," Philological Quarterly, William Kupersmith, ed., vol. 66, no. 2, Spring, 1987 (Iowa City: The University of Iowa, 1987) 231 . 
The symbolic Eyes of God appear first in The Four Zoas as spirits of God made immanent to protect "mankind from deepest error." This state of error is Satan's domain; it is the inner state of error. In Blake's portrayal of Satan in Satan in His Original Glory (Figure 7), this human condition of error is shown; in Jerusalem, Blake identifies Satan as the "Spectre of Albion! warlike Fiend! / In clouds of blood \& ruin roll'd: / I here reclaim thee as my own / My Selfhood! Satan! armd in gold."122 The imagery of vortices, implied by the whirling conformation of wheelmolecules, unlike Descartes's mechanistic paradigm for the generation of matter, implies the churning mental energy invoked during the imaginative visionary act; the Cherubim's gaze is penetrating through the apex of interconnecting vortices into the opening womb of eternity. Like Dante's journey in The Inferno, "With limits set to man's fall, his path is made circular and he therefore finally progresses upwards." 123 This Cabbalistic involution is accomplished symbolically through the neck at interfacing twin vortices where temporal and eternal time meet.

The Eyes of God symbolism "is founded on central

122 William Blake, Jerusalem, Plate 27, lines 73-76, Blake's Poetry and Designs, Mary Lynn Johnson and John E. Grant, eds. (New York: W.W. Norton \& Company, Inc., 1979) 323.

123 Rachel V. Billigheimer, "Blake's 'Eyes of God': Cycles to Apocalypse and Redemption," Philological Quarterly, William Kupersmith, ed., vol. 66, no. 2, Spring, 1987 (Iowa City: The University of Iowa, 1987) 235 . 
biblical images in Exodus, Ezekiel, Zechariah and

Revelation."124 All of these sources allegorize spiritual

illumination with symbolic eyes and wheels to promote

insight from temporal to eternal perception. In Ezekiel's

Wheels (Figure 1), "the eyes moving in all directions in the wheels of the chariot of the Deity which is drawn by the divine power of the zoas symbolize the omniscience of the divine spirit." 125 Blake also derives the symbolism of the eyes of God from "the mystical writings of Boehme and

Paracelsus and from habbalistic and monastic sources." $12 \hat{0}$

In God Blessing the Seventh Day (Figure 5), Blake creates an "image of Eternity, the opened Center, which contains all

Seven Eyes of God and all eras of human time."127 This visionary portrayal of the seven manifestations of the divine is in the form of a mandorla; its finials are formed

124 Rachel V. Billigheimer, "Blake's 'Eyes of God': Cycles to Apocalypse and Redemption," Philological Quarterly, William Kupersmith, ed., vol. 66, no. 2, Spring, 1987 (Iowa City: The University of Iowa, 1987) 233.

125 Rachel V. Billigheimer, "Blake's 'Eyes of God': Cycles to Apocalypse and Redemption," Philological Quarterly, William Kupersmith, ed., vol. 66, no. 2, Spring, 1987 (Iowa City: The University of Iowa, 1987) 233.

126 Rachel V. Billigheimer, "Blake's 'Eyes of God': Cycles to Apocalypse and Redemption," Philological Quarterly, William Kupersmith, ed., vol. 66, no. 2, Spring, 1987 (Iowa City: The University of Iowa, 1987) 235 .

127 Mary Lynn Johnson, "Human Consciousness and the Divine Image in Blake's Watercolor Designs for the Bible: Genesis through Psalms," The Cast of Consciousness: Concepts of the Mind in British and American Romanticism, Beverly Taylor and Robert Bain, eds. (New York: Greenwood Press, 1987) 25. 
by wingtips similar to those over Satan in Satan in His Original Glory (Figure 7). Blake uses all of these standard metaphysical symbols for spiritual illumination in his dramatization of visionary imagination; wings imply imagination and spirit, the mandorla is a cosmic symbol for wholeness which here has the additional indication of womb of spirit, and the Seven Eyes of God indicate progressive eras toward insight.

Mark Schorer points out that Blake opposes the mechanistic world view with the "ancient concept of macrocosm and microcosm...to counter the prevailing mechanical view of man and the universe with his own organic view."128 Consequently, as previously stated, the other major oeuvre which informs Blake's work besides the Bible is Ovid's Metamorphoses, together notably with Ovid and Milton; by interpreting The Bible in its "diabolical sense," to invoke Northrop Frye's phrase, ${ }^{129}$ Blake iconoclastically appropriates the standard biblical exegetical technique to demonstrate that the integrated human state is divine. This is recognized through the transformative power of the visionary imagination, which he stimulates by dramatizing it with persistent, recurrent, standard motifs creatively

128 Mark Schorer, william blake: The Politics of Vision (Gloucester: Henry Holt and Company, Inc., 1975) 108-109.

129 Northrop Frye, Fearful Symmetry: A Study of William Blake, 4 th. ed. (Princeton: Princeton University Press, 1974). 
recombined with idiosyncratic eidetic imagery and deliberately distorted Gothic iconography.

\section{Vortices as Symbols}

Blake's symbolism for visionary imagination of recurrent motifs of eyes and vortices also expresses its corollary non-temporal, non-spatial orientation. He conceives of eternity as the temporal world inverted or turned inside out; his image is analogous to the image of an hourglass through which transformation must occur at the channel between states; rather like the externalization of an inner, psychic realm, as if the self's evaluating system had been turned inside out from sight into insight; ${ }^{130}$ this is more profound than Protagoras's principle that "Man is the measure of all things," since it is possible only as the result of inspired vision and entails recognition of one's own evaluating system. Consequently, it penetrates momentarily the cultural envelope, or to apply Northrop Frye's metaphor, one sees through the carriage window rather than perceiving only the reflection in the glass. The result is proper vision, which Blake describes in quasiCabbalistic or Gnostic terms in Milton:

The nature of infinity is this: That every thing has its / Own Vortex; and when once a traveller thro' Eternity / Has passed that Vortex, he perceives it roll backward behind / His path, into

130 Annie Dillard, Pilgrim at Tinker Creek (New York: Quality Paperback Bookclub, 1974). 
a globe itself infolding. 131

The vortex is vestigial in Newton (Figure 8 ) as a tiny coil at the end of his scroll, in front of him rather than rolled "backward behind," to indicate his fixity within the pragmatic realm of the geometer superimposing rational order on the world. Conversely, the vortices are expansive in Ezekiel's wheels (Figure 1) and filled with cosmic eyes to denote the Zoa-Cherubim's mastery over eternity through the transformative power of visionary imagination. Commenting on Blake's Cherubim, David Sten Herrstrom refers to its subsequent perversion:

Ezehiel's Cherubim vision became the paradigm in Blake's mind not only for the clarity and unity of vision but for the shape and method of his epic prophecy, its demonic parody in the form of Ezehiel's "Covering Cherub" also became important.

The Cherubim, which represents ideas, ${ }^{133}$ elsewhere becomes perverted into a false parody of itself as the Covering

131 William Blake, Milton, Plate 15, line 21-24. Blake's Poetry and Designs, Mary Lynn Johnson and John E. Grant, eds. (New York: W.W. Norton \& Company, Inc., 1979) 258.

132 David Sten Herrstrom, "Blake's Transformations of Ezekiel's Cherubim Vision in Jerusalem," Blake: An Illustrated Quarterly, Morris Eaves and Morton D. Paley, eds., vol. 15, no. 2, Fall, 1981 (Berkeley: University of California, 1981) 65 .

133 "The Cherubim of God are the spirits of understanding which are forgiveness. The Cherubim of Man are the four Zoas, the 'four living creatures' of Ezekiel ( $J$ 63:2)," S. Foster Damon, A Blake Dictionary: The Ideas and Symbols of William Blake, Rev. ed. (Hanover: University of New England, 1988) 80 . 
Cherub; ${ }^{134}$ this is mistaken for the true Cherubim as Jehovah is the Hebrew misconception of divinity the more difficult to displace because obscurantist as opposed to transparent. Blake satririzes this with his "Nobodaddy" god of The Ancient of Days to alert his audience to its falsity. Yet truth is also embedded in the image as he sweeps away such obfuscation with plates to be read directly. As David Sten Herrstrom observes, "Blake's prophecy is not a vehicle for vision, a means of attaining the mystical end of spiritual transport, but the body of the word itself in its most disturbing fullness."135 His plates present spirit observed, the idea made manifest, name and image named; Blake demonsrates word as distinctly as the Image of his surrealistic eidetic imagery; together, they rearticulate the method of the iconostasis' lurid 'speaking picture' as a means to visionary imagination.

To invoke this visionary imagination in Adam Naming the Beasts (Figure 2) and Christ Blessing (Figure 3 ), the

131 "The covering cherub is the final error, the last enemy to be slain. The term comes from Ezekiel xxviii:16: 'I will destroy thee, O covering cherub, from the midst of the stones of fire'.... The ultimate meaning of the Covering Cherub is the selfhood ( $J$ 89:10; $96: 8$ ) that self-seeking which is the root of all the Christian errors," S. Foster Damon, $\underline{A}$ Blake Dictionary: The Ideas and Symbols of William Blake, Rev. ed. (Hanover: University Press of New England, 1988) 93.

135 David Sten Herrstrom, "Blake's Transformations of Ezekiel's Cherubim Vision in Jerusalem, "Blake: An Illustrated Quarterly, Morris Eaves and Morton D. Paley, eds., vol. 15, no. 2, Fall, 1981 (Berkeley: University of California, 1981) 98. 
disembodied eye motif, symbolic of insight and spiritual

illumination, becomes humanized in the level, engaging gaze of Adam and of Jesus; the viewer is invited to focus inwardly, as if holding up the mirror to nature, on his own potential for visionary imagination. There is no mystification about this process, for Blake was unambiguous with regard to his "intellectual vision," as Mark Schorer states:

Blake's vision is the perception of symbols for his myth, and the poems that were based on this perception he was careful to distinguish from allegory by the clumsy expression "Allegory addressed to the Intellectual powers." The visionary poet is the man who by the breadth and penetration of his perceptions, his "Copiousness of glance," discovers the materials which compose these allegories "addressed to the Intellectual powers."

This "Copiousness of glance" is syncretistic or synoptic vision which perceives simultaneously figure and ground as the integrated entire Gestalt; this is the human form infused with spirit, as body and soul (image and word) are unified by visionary imagination, which penetrates beyond literalism. Blake's depiction of the "Human Form Divine" in its Zoahood as the Cherubim in Ezekiel's Wheels (Figure 1) dramatizes visionary imagination as vortex energy, symbol for higher perception. The physical eye sees body, while the insight perceives soul.

136 Mark Schorer, William Blake: The Politics of Vision, Rep. (Gloucester: Peter Smith, 1975) 97-98. 
As already seen, mere vestiges of this vortex energy appear in Blake's Newton (Figure 8) to satirize the repression of intuition by rational logic. The expansive vortex is compressed into a tidy scroll, rolled up like an ineffectual magic carpet, symbol for the potential of imaginative flight, or of a temporal-spatial realm far beyond the third dimension about which modern physics speculates. In Newton (Figure 8 ), this vortex is reduced to appear as a

tiny coil at the end of Newton's scroll...[which] is quite literally the 'end-point' of the twodimensional world in which he creates abstract forms. When he has persisted in his heroic folly long enough, "Creating many a Vortex fixing many a Science in the deep" (FZ, 72: 13, E 342), he will become wise, all his abstract reductions rolling up in a prophetic scroll, a living spiral absorbing the conic section (circle and triangle) that he is inscribing. The circle will then be squared or made "fourfold" not by being enclosed in a box, but by coiling into a vortex which leads to a new level of perception.... [Since Blake's infinite is] immanently in the intense dialeftical perception of... particulars.

The visionary imagination, together with access to the eternal realm, is constrained into a coiled, potential or vestigial vortex in Newton (Figure 8), the scroll of sophism, because the sceptical philosopher-mathematician seeks in the wrong direction. To extend the metaphor of an hourglass, Blake describes true vision as seeing beyond the

139 W.J.T. Mitchell, Blake's Composite Art: A Study of the Illuminated Poetry (Princeton: Princeton University Press, $1978) 73$. 
vortex as it rolls up behind the emerging figure at the apex between the two conic sections of an imaginary hourglass. The Cabbalistic and Alchemical symbol for this is the lemniscate, schematically represented by the horizontal figure eight. Deluded into perceiving exclusively quotidian concerns, Newton faces toward the 'bottom' of the conic section, rather than facing its apex. Blake indicates that logical literalism is the wrong focus as clearly as Newton's looking down instead of above, or forward in the manner of the Cherubim in Ezekiel's Wheels (Figure 1).

The supremacy of rationality over higher intuition is also reflected in the cramped posture of the figure of Newton. His physique is deliberately classical to parody traditionalism's love for mathematical proportions and its tendency to repetition; it is "based on Michelangelo's representaion of the prophet Abias in the Sistine Chapel."138 Unlike the Cherubim of Ezekiel's Wheels (Figure 1), who sees through apparencies directly into the womb of eternity, Newton sits sideways, his glance preoccupied with material concerns. He faces downward in the performative gesture of the geometer inventing proscribed limits with the golden Urizenic compasses, symbolic of rational intellect as repression of the higher imagination. Newton is folded into a posture which echoes

138 William Vaughan, William Blake, Plate 12, (London: John Calmann and Cooper Ltd., 1977). 
the triangularity of the compasses as they bisect the triangle drawn at the bottom of the scroll with an arc in the process of creating his abstract conic section. The triangle motif recurs throughout Newton (Figure 8). Newton's nose, chin, and entire head are triangular, like a rearticulation of the compasses with the top of his head analogous to its hinge; his profile and eyelids are triangular; triangular lashes frame concealed eyes, which therefore are incapable of metaphoric vision, insight, or transmission of divine essence; unlike the Cherubim, there is no confrontational insight; highlighting on his muscles is triangular; the rock on which he sits hunched over his compasses is triangular; angles articulated by his hands are triangular. In a superlative satire on classicism's love for mathematical proportion and repetition, Newton is the personification of "Greek Mathematical form" as opposed to the "living Gothic" exemplified by the Cherubim's organic eyes and wheels in Ezekiel's wheels (Figure 1), while his hand and eye perform mechanically to literalize abstract triangles dictated by his triangulating eye, hand, and brain. Only the triangularly spined sea urchin-shaped organisms at the earthiest level of his heels, is drawn inexorably in streaming movement toward the potential vortex of dynamic energy coiled up in the scroll beyond the compasses at his toes. Newton has metaphorically descended to the level of the mineral pebble, the lowest 'soul' in 
Aristotelian terms. In Newton (Figure 8), Blake presents a mathematical conundrum to satirize sceptical rationalism and mechanistic physics:

The Idea is the Being or Reality of the particular sensible triangles.... Therefore, there is such a thing as objective knowledge and Protagoras was wrong. With reason Plato inscribed over the entrance t $\beta_{9}$ the Academy NO ONE WITHOUT GEOMETRY MAY ENTER.

Newton practices his abstract geometry, an exemplar of Baconian empiricist analysis in the tradition of Milton's Puritannical plain style intended to appeal to logic rather than to carnality, 140 but which is Newton's perfect Cartesian triangle?

In his visionary plates, Blake counters the angular stasis of the triangle with the organic volatility of the vortex. Kathleen Raine finds the vortex symbolism in a Gnostic interpretation implicit in God Blessing the Seventh Day (Figure 5). "But the Workman, Mind together with the Ford, containing the circles, and whirling them about, turned round as a wheel, his own Workmanships."141 Idea expressed becomes creation as image contains meaning. The design of God Blessing the Seventh Day (Figure 5) is also

139 Wallace I. Matson, A New History of Philosophy: Ancient and Medieval, Vol. 1 (New York: Harcourt Brace Jovanovich, Inc., 1987) 89.

110 Stanley Fish, Surprised by Sin: The Reader in Paradise Lost (New York: St. Martin's Press, 1967) 6 .

111 Raymond Lister, The Paintings of William Blake (Cambridge: Cambridge University Press, 1986) Plate 39. 
similar to a roof boss at York Minster drawn by Flaxman and possibly seen by Blake, who was certainly familiar with roof bosses. Its design is also reminiscent of the principle of microcosm within the macrocosm like the spiritual womb of eternity with a vestigial umbilical cord trailing at its base. Blake's finding immanence in particulars is a rearticulation of this microcosm within the macrocosm paradigm, but his expression of it takes physics into account, for he does not deny the reality of physics but rather eschews a tyrannical emphasis on the mundane to spirit's exclusion. He reconciles the Cartesian dualism derivative of the split between idealism (Plato's a prioris of perfect Ideas or Forms of triangles et al. which can exist independently of perceived experience) and sensory engagement (Protagoras's admission of the subjective nature of reality, "as a thing appears to a man, so it is for that man"). 142 The mind / body dichotomy (ideas / senses; abstract / concrete), initiated by the Greeks and codified by Descartes, Blake reconciles through his dramatization of visionary imagination which is able to unify body and soul through image and word understood synergistically. But he also exults in the organic vitality which ensues from the dynamic tension resulting from oppositions. His "Auguries

142 Wallace I. Matson, A New History of Philosophy: Ancient and Medieval, vol. 1 (New York: Harcourt Brace Jovanovich, Inc., 1987) 68 . 
of Innocence" expresses this holistic vision, which perceives similarity in apparent dissimilarity and sees the extraordinary in the ordinary. Since it represents a brilliant distillation of his philosophy, it is worth quoting a second time:

To see a World in a Grain of Sand And a Heaven in a wild Flower Hold Infinity in the palm of your hand And Eternity in an hour

To 'see' this microcosm within the macrocosm entails the same type of visionary imagination needed to transform a thistle into a bearded old man across the path. Blake's allegorizing capacity is inherited from Gothic iconography which incorporated pagan elements of folk lore with orthodox Christian motifs. This Medieval tradition comfortably anthropomorphized nature to easily perceive Wild Clematis as Old Man's Beard and Capsella bursa-pastoris as Shepherd's Purse. ${ }^{144}$ Blake enlivens and broadens this folk tradition, while enhancing his mythopoeic vision by appropriating folk imagery common in Medieval iconography to oppose Greek rationalism with Gothic organicity. As Peter F. Fisher observes:

143 William Blake, "Auguries of Innocence," 1 ines 1-2, The Pickering Manuscript, Blake's Poetry and Designs, Mary Lynn Johnson and John E. Grant, eds. (New York: W.W. Norton \& Company, Inc., 1979) 209.

144 W. Keble Martin, MA, DSc, FLS, The Concise British Flora in Colour, Second Revised Ed., London: George Rainbird Limited, 1969, Plate 10. 
He was the professed opponent of the Greek spirit of compromise and adjustment between the state of nature and society. For he considered the rationalism of the philosophers a disguised attempt to discredit the inspired insight of the seer and provide instead some kind of external standard of knowledge and behaviour.

Politically, he found in Greek rationalism the beginning of the utopian ideal of society which pretended to be a protection against the titanism of the despot and the tragic sin of hybris. But this kind of thinking seemed to him to lead to the theoretical rule of reason in the conduct of affairs and the tyrannical use of law as an absolute background to the very kind of political power which the theory was supposed to prevent. 145

According to Peter F. Fisher, this kind of thinking was the origin of the unholy union of king and priest which threatened to destroy the roots of individuality and to generate an organized deception; this appalled Blake and he used the figure of Urizen to satirize the tyranny he associated with all hierarchical structures as the nemesis of the "Human Form Divine." Urizen also symbolizes the idea of Hebrew (and Druidic) priesthood conflated with that of royalism, then being challenged in Revolutionary France and America of the late eighteenth century, as it had been abrogated in earlier seventeenth century England by oliver Cromwell's beheading of Charles I to destroy the illusion of the Divine Right of Kings and to inaugurate what was envisioned as an egalitarian Commonwealth, it dramatically disrupted the Great Chain of Being paradigm. Urizen is a

145 Peter F. Fisher, The Valley of Vision (Toronto: University of Toronto Press, 1961) 3 . 
symbolic attack on unalloyed materialism and creativity's nemesis of mechanistic repetition at the beginning of the Industrial Revolution, as well as invective against religious orthodoxy's insistence on the need for an intercessor. Blake extends Protestantism's belief in a direct relationship with Christ through the transformative power of the visionary imagination. Blake's objections to orthodoxy's legalistic, hypocritical constraints coalesced into an image of warped stasis, which apotheosizes the tyranny of authoritarianism, strictures of mechanism, and spiritual oppression--all anathema to visionary imagination-in his title figure to The Book of Urizen. Urizen hunches beneath his Gothic arch absorbed in his twin tablets of the Law; his downcast gaze is as unseeing as Newton's in Newton (Figure 8).

Urizen also symbolizes Rlake's abhorrence for Newtonian physics and sceptical philosophy; through his satiric figure of Urizen, Blake warns that the absence of imagination "is the End of Epicurean or Newtonian Philosophy. It is Atheism. ('Annotations to Reynolds,'p. 649)."146 In Blake's epic, The Four Zoas, the aspect of the fragmented Albion which represents Urizenic sceptical rationalism exerts "sterile efforts to reduce the universe into a precise and predictable machine in which the turning wheels

146 David V. Erdman, ed., The Poetry and Prose of William Blake (Garden City: Doubleday, 1970) 66. 
of heaven operate with inexorable exactness (Night VI, page 73, 1. 23; p. 343)" in which "Urizen's mechanistic vortexscience [is] ...spiritually and imaginatively destructive."149 Newton symbolizes the subversion of visionary imagination by reductionistic logic and the perversion of expansive vortex energy into the service of two-dimensional schematic emblems of mechanism.

In contrast with Newton's Urizenic perversion of vortex energy, Ezekiel's wheels (Figure 1) shows the vortices of churning energy surrounding the central Zoa as a caduceus motif to express the unity of form and idea. According to Clyde R. Taylor, the instinctual life symbolized by the serpent is supplanted by the wings of imagination. 148 Imagination, however, reconciles the chthonic and ethereal elements.

In both Satan in his Original Glory (Figure 7) and Ezekiel's wheels (Figure 1), the predominant use of gold tones indicates the "Abstract God which is the product of man's 'wearied intellect" "; 149 but in Ezekiel's Wheels

14? Bryce J. Christensen, "The Apple in the Vortex: Newton, Blake, and Descartes," Philosophy and Literature, vol. 6 , no. 1 \& 2, Oct., 1982 (Dearborn: The University of Michigan, 1982) 158 .

148 Clyde R. Taylor, "Iconographical Themes in william Blake," Blake Studies, Kay Long and Roger R. Easson, eds., vol. 1, no. 1, Fall, 1968 (Tulsa: University of Tulsa, 1968) 56 .

149 S. Foster Damon, A Blake Dictionary: The Ideas and Symbols of William Blake (Hanover: University Press of New England, 1988) 162 . 
(Figure 1), the opposition exists between Urizen, "Abstract God," and the spiritual sun represented by Los, the Zoa of imagination. The two forms of intellect are reconciled through the visionary positioning of the central axis of Cherubim amid swirling eye-vortices to symbolize merger between stasis and anastasis; this represents the interface of interconnecting vortices of temporal-spatial with eternal time, which is actually the experience or perception of complementary aspects of the self. While in Newton (Figure $8)$, the reiteration of the limiting triangle and arc, the conic section motif symbolizes Greek rationalism superimposed on the world through the reductionistic Urizenic compasses of Iimitation, in Ezekiel's Wheels (Figure 1), the three-dimensional vortices are implied with the Zoa-Cherubim's penetrating vision seeing directly into the womb of eternity. Intellect, in the sense of logic as opposed to intuition, is a function of the constrictive Urizen. For Blake, Newton is the apotheosis of mathematical logic. As Christensen remarks, "With the publication of his 'Song of Los' in 1795, Blake signalled the beginning of an attack which he continued...for twenty years."150 Blake opposes mechanism with the uniqueness of his Gothic "living form" and his devout belief in the powers of the

150 Bryce J. Christensen, "The Apple in the Vortex: Newton, Blake, and Descartes," Philosophy and Literature, vol. 6 , no. 1 \& 2, Oct., 1982 (Dearborn: The University of Michigan, 1982) 156 . 
imagination; these coalesce into his "Human Form Divine" made manifest in his Christ Blessing (Figure 3 ). The individuality of all of the figures and the organic decoration in his iconic plates articulate their deliberate humanistic personalization and Gothic elements. Their intense colors and discrete forms also express eidetic influences which are typically surrealistic. The combined effect is startlingly lurid like the iconostasis, which also intended to stimulate visionary imagination into activity by penetrating mundane veils.

W.J.T. Mitchell accuses Blake of using "radical anthropocentrism" to affirm an "infinite" perception; he says,

Blake uses the word 'vortex' rather than 'genius' or 'essence' because he wants an image that suggests both convergence toward a center or apex (the 'inner being' of the object) and doubleness, the interaction of contrary forces. A thing is what it is, and what we see it as. Blake is saying that we can never abolish one of these modes of existence as an illusion and elevate the other to reality. What we can do is intensify the dialectic between them until we comprehend the thing, and feel ourselves comprehended. That is why the view of a thing when we have passed the vortex is both intimate and personal, like a friend, and vastly alien anf, impersonal, like a universe of starry majesty.

Since the only experience of essence is in the human mind, however, we can never know the essence of the Other. The moment we perceive the Otherness, we recognize that it

151 W.J.T. Mitchell, Blake's Composite Art: A Study of the Illuminated Poetry (Princeton: Princeton University Press, $1978) 72$. 
exists in what Immanuel Kant designates as the realm of the noumena; it becomes as W.J.T. Mitchell points out "vastly alien." Blake propels his audience toward this recognition with the insistence of his plates.

\section{Imagination In Opposition to Mechanistic Physics}

While in Newton (Figure 8), Blake portrays the mundane geometer, in his The Ancient of Days, Blake depicts the cosmic geometer; he satirizes simultaneously Newton and Milton as well as Aristotelian systematic logic and Platonic ideal Forms with his figure of "Nobodaddy." In The Ancient of Davs, his parody of classicism's primum mobile and orthodoxy's legalistic Jehovah-Creator, with spikey beard and triangulating hoary hair streaming, leans out of the sphere of eternity or the soul in order to measure out in the void a universe external to mind or intellect.... For Blake there is no "second creator" no demiurge, but in man's own mind; the divine creation, "truth, or eternity," is untouched by human "error, or creation," which is "burnt up the moment men cease to behold it." The name must have come to Blake out of his damning reflections on Milton's "Almighty Maker," and was perhaps suggested by the grand opening passage of the account of the Creation, illustrated in his composition.

The pair of compasses, of Urizenic gold (Ur 20:39; FZ ii:29), which occurs in Milton's Paradise Lost (VII, 22431 ), is an obvious reference to the mechanistic view of the

152 Kathleen Raine, Blake and Tradition, Vol. II, Bollingen Series XXXV (Princeton: Princeton lniversity Press, 1968) 58 . 
cosmos already seen in Newton (Figure 8). William Vaughan comments that "Dividers, a traditional attribute of God as creator, were frequently used by Blake as an image of soulless construction as in Newton." 153 John Donne uses the same metaphor, typically with a vastly different nuance; like Descartes, Donne was not antipathetic toward science as is evident in his "A Valediction Forbidding Mourning." The compass metaphor in Donne implies the possibility of composing one's own mental universes, but also acknowledges the compatibility of idealism with natural science. For Blake, however, this symbol does not apply exclusively to, but coalesces into a symbolic attack directed at, Newton. According to Kathleen Raine, Plato's sphere forms the base in The Ancient of Days from "the plenum [of which] the demiurge leans out into the void--'the void outside existence' of physical space."154 The compass becomes the cypher for Blake's excoriation of the empiric philosophy with Newton as its most recent and influential target. Blake, understanding early eighteenth century natural philosophy and its classical Greek and Roman antecedents, intended precisely to exploit a popular target of his era because it would be recognized more readily than the

153 William Vaughan, William Blake, Plate 8. Europe, a Prophecy; the Ancient of Days (London: John Calmann and Cooper Ltd. , 1983 ).

154 Kathleen Raine, Blake and Antiquity (Princeton: Princeton University Press, 1977) 58 . 
sceptical rationalism promulgated by pre-Socratic, Platonic, and Aristotelian philosophers.

It is ironic that Newton's religious philosophy as expressed in his non-scientific writings and Blake's conception of the divine seem so little apart; that a fundamental influence on Blake's art was Gothic structure, which is a product of mechanistic physics intended as body to express soul through iconographic ornamentation and meant to imply spirit with its womb-like spaces. Subsequent to the disruption in the Great Chain of Being paradigm initiated in the Age of Reason and codified during the Enlightenment, metaphysicians sought new orders; in their search, they went inward. Blake is their avatar with his exultation of the transformative powers of visionary imagination; his work unifies body and soul to lucidly articulate this. Minna Doskow remarks Blake's identification of God with imagination; she says,

Blake's God... is inseparable from the human imagination at work. As he tells us in his "Annotations to Berkeley's Siris," "Man is All Imagination God is Man \& exists in us \& we in him" ( $E$, p. 654). For him, the only God is incarnate in human beings, "the Human Form Divine," and this puts him iff conflict with religious orthodoxy.

This is Blake's concept of the "Human Form Divine." His

155 Minna Doskow, "William Blake and the wheels of Compulsion," History \& Myth: Essays on English Romantic Literature, stephen C. Behrendt, ed. (Detroit: Wayne State University Press, 1990) 63. 
humanism or anthropocentrism opposes the divine conceived of as an abstraction in an ethereal realm such as Plato's Realm of the Good which represents perfect Idea. Closer to Blake's idea of the divine is the conception expressed in an early Medieval text; although reminiscent of Plato's ideal sphere, it includes sensate humankind in The Book of the Twenty-four Philosophers (Liber XXIV Philosophorum): "God is an infinite sphere, whose center is everywhere and circumference nowhere."156 Yet Blake's ontology is broader; while satirizing orthodoxy's misconstrued reliance on logical syllogisms, he parodies codifications with ascerbic satire of Aristotelian system: "If you have formed a Circle to go into / Go into it yourself \& see how you would do."15? This would be an encompassing God as opposed to an inner divinity reflected in each individual, the impossible sum of which, given humanity's constant flux of Iife and death, represents Liber XXIV Philosophorum's entire divine. Like Saint Anselm's ontological argument, it seems logically irrefutable and therefore anathema to Blake, who eschewed codification and trite, reductionistic platitudes, which he opposed with ironically gnomic aphorisms.

156 Joseph Campbe11, The Inner Reaches of Outer space: Metaphor as Myth and as Religion, Perennial Library Ed. (New York: Harper \& Row, 1988) 44 .

157 Willaim Blake, "To God," III.Vision, Blake's Poetry and Designs, Mary Lynn Johnson and John E. Gran, eds. (New York: W.W. Norton \& Company, Inc., 1979) 183. 
The imagery implied in the Newtonian postulate of attraction of matter through a vacuum or Descartes's theory of energy vortices, recurrent in several of Blake's plates as seen, is most obvious in Ezekiel's Wheels (Figure 1), where it symbolizes visionary imagination; it becomes like John Donne's imagination-driven compasses, not stylistically but thematically, in the respect that its dynamic energy can bring universes into existence. Such convolution of matter or swirling of atoms in a vortex is torsion. George Quasha in "Orc As a Fiery Paradigm" affirms that Blake's philosophy opposes the 'flat' circle paradigm:

The birth or rising of Orc, seen in archetypal perspective as the first phase of a cycle, has come to seem an inevitable component of Blake's meaning....Blake's poetic system...strove for escape from circular closure in space and

Blake achieves this by means of his vortex symbolism, which elevates the two-dimensional circle to the three-dimensional realm of kinaesthetic experience. This energy dynamism is what Harold Bloom, as previously observed, refers to as the Devourer receiving hte plenitude of the Prolific in cyclic adjustment. "Orc, then, is not only Blake's Prometheus but his Adonis, the dying and reviving god of his

158 George Quasha, "Orc as a Fiery Paradigm," Blake's Visionary Forms Dramatic, David V. Erdman and John E. Grant, eds. (Princeton: Princeton University Press, 1970) 263. 
mythology."159 There is a cyclic inseparability of the opposing principles represented by Orc and Urizen which is the dynamic tension of organic energy. This vortex of generative energy is represented by the twisting, swirling movement in several of Blake's plates, indicative of the additional influence of Baroque and Mannerist art. The eyes within starry wheels, which rotate around the hieratic quatro-headed Cherubim in Ezekiel's Wheels (Figure 1), represent the stages of imaginative evolution. Quasha comments on Blake's manner of visionary imagination:

Blake's mode of visionary thought, as Frye demonstrates extensively, involves each poetic meaning, in the furthest possible ranges of a dynamic metaphoric system. His mental habit of seeing every Particular as containing the cosmos-ontogony recapitulating phylogony--relates him to the earliest mythopoeic thinkers. Recognition of the creative act (poiein) as a metaphor for its own process--a Zagreus-Dionysus myth--is characteristic of the ancient oral-traditional, order, truth, and vision--as a craft and as literal performance. Art delights in art (to paraphrase Blake's "Life delights in life") and is self-begetting....Verbal invention came to imply perpetual revolution within the expanding vortex of human consciousness. And the violent birthlike experience of apocalypse he embodied in a language structure which from our vantage point resembles organic evolution: a cumulative, temporally linear, unpredictably irregular progression toward more complex forms. 160

159 George Quasha, "Orc as a Fiery Paradigm," Blake's Visionary Forms Dramatic, David Erdman and John E. Grant, eds. (Princeton: Princeton University Press, 1970) 263.

160 George Quasha, "Orc as a Fiery Paradigm," Blake's Visionary Forms Dramatic, David Erdman and John E. Grant, eds. (Princeton: Princeton University Press, 1970) 264-265. 
Blake expands the "vortex of human consciousness" in his plates to include the viewer in a dialectic of imagination. The imaginative vortex design, symbolic of 1 ife-force and imagination, is incipient in the curvilinear Gothic decorative elements of Blake's scenic backgrounds to plates such as Adam Naming the Beasts (Figure 2). The imagery of vortices recurs through many of his non-biblical plates in addition to Ezekiel's Wheels (Figure 1). It represents the involuting energy of organic life; while embodying a Gnostic and Cabbalistic principle, it is also a decorative style which Blake characterizes as Gothic's "living form" in harmony with its organic origins. ${ }^{161}$

\section{Convolution Motifs as Symbols for Levels of Consciousness}

As stated, at the imaginative level vortices symbolize visionary experience. Blake's poesy, such as "Ah, Sunflower," expresses thematically the convoluting motion of

16! Among the High Romantics of the late eighteenth and early to mid-nineteenth centuries, who tended to think that the imagination was autonomous, Samuel Taylor Coleridge invoked the Promethean metaphor to advance his theory of the "esemplastic power". or "innate" organic form of the creative process ("Preface" to the Lyrical Ballads); Shelley developed this into the idea that "the mind in creation is as a fading coal, which some invisible influenmce, like an inconstant wind, awakens to transitory brightness: this power arises from within," "A Defence of Poetry," Romantic Poetry and Prose, Harold Bloom and Lionel Trilling, eds. (New York: Oxford University Press, 1973) 758. Wordsworth referred to creativity as inspired by the "spontaneous overflow of powerful feelings" recollected in tranquillity, "Preface to the Lyrical Ballads" of 1802, Romantic Poetry and Prose, Harold Bloom and Lionel Trilling, eds. (New York: Oxford University Press, 1973) 596. 
natural phenomena, such as the coiling energy of tendrils or of heliotropic stems, as symbols for life stages at a vegetative level of consciousness; ${ }^{162}$ Blake's plates embody this metaphor stylistically, making soul visible. Albion's pose in Glad Day (Figure 4) is irradiated by a sunburst of cosmic energy like an exploded Gothic aureole, symbolic, of expanded consciousness and spiritual regeneration. Klomp and Stevens's comment on the inverse significance of sun imagery is helpful toward an understanding of Gothic's iconographic manipulation of symbols for natural cycles; they say,

The convention of metaphorical coherence concerns the assumption that a poem [or a painting] will cohere or will make sense both on a literal and on a metaphoric level. Readers recognize the literal way in which a sunflower turns toward the sun and also the figurative statement about human aspiration. The convention of poetic tradition allows readers to assume allusions used in other poetry and justifiess, for instance, an equating of sunset and death.

Conversely, in Glad Day (Figure 4), Albion's ecstatic gesture combined with the radiant cosmic energy bursting from his human form equates more to a universal sunrise. To the visionary imagination, however, Albion's aureole surpasses even the most brilliant of natural sunlight; it

162 Bonnie Klomp Stevens and Larry L. Stewart, A Guide to Literary Criticism and Research, 2nd. ed. (New York: Harcourt Brace Jovanovich College Publishers, 1987) 39.

163 Bonnie Klomp Stevens and Larry L. Stewart, A Guide to Literary Criticism and Research, 2nd. ed. (New York: Harcourt Brace Jovanovich College Publishers, 1987) 39. 
comes to represent the non-spatial, non-temporal eternal moment of regeneration irradiated as divine illumination emanating outward from his anastatic human form animated with boundary-dissolving ecstasis.

The implicit iconographical significance of climatic seasons and their metaphoric correspondence to human cycles is a visual reiteration of human regeneration. It is represented by the cyclic stages of vegetation which appears in Adam Naming the Beasts (Figure 2). It is particularly apparent that Blake's foliage, typical of Medieval iconography and congruent with biblical polysynchronous time, incorporates several seasons simultaneously; it also reflects certain decorative elements of $\mathrm{High}$ and Late Gothic as shown in the curvilinear stipules to the oak leaves and their wavy margins in Adam Naming the Beasts (Figure 2 ). This type of trompe de l'oeil detailing and precision are also typical of eidetic imagery and contribute to its surreal quality. These death-in-life motifs symbolize the cyclicity of the human condition; High and Late Gothic's decorative emphasis on vegetation is described by Emile Mäle, who says,

The stone flora of the Middle Ages seems to follow the laws of nature. The cathedrals had their springtime and their summer, and when the thistle of the fifteenth century appeared they had their 
autumn too. 164

The naturalistic effect achieved by Late Gothic decoration is found taken to excess in the Chapel of Henry VII at Westminster Abbey, where Blake was apprenticed to Basire in the 1770s; it is evident that in the ceiling ornamentation,

The linear play of ribs has become a kind of architectural embroidery pulled into "fan vault" shapes with pendent keystones resembling stalactites. The vault looks like something organic that has been petrified in the process of melting. The chapel represents the dissolution of structural Gothic into decorative fancy, its original lines being released from function and multiplying, variegating, and flowering into uninhibited architectural virtuosity and theatrics.

The mannered, cloisonné effect of this dainty fan vaulting reappears in the background reticulation of deciduous branches of Adam Naming the Beasts (Figure 2). Symbolic of life-stages or levels of consciousness, fecund organicity is represented by the blue of materiality, resonant with the Zoa Tharmas, in curvilinear lava-like terrain beneath Albion's feet in Glad Day (Figure 4), while the twining vine and trefoil-patterned foliage reminiscent of oak leaves, so typical of High Gothic art, frame Adam in Adam Naming the Beasts (Figure 2). But, again, this minute detailing is also typical of eidetic imagery as well as expressive of

164 Emile Mäle, The Gothic Image: Religious Art in France of the Thirteenth Century, trans. Dora Nussey (New York: Harper \& Row, Publishers, 1972) 52 .

165 Louise Gardner, Art through the Ages, 7th. ed. (New York: Harcourt Brace Jovanovich, Publishers, 1980) 344-345. 
Blake's fundamental philosophy of the primacy of imagination. As S. Foster Damon observes,

The minuteness of detail in Blake's visions led naturally to his stressing the "Minute Particulars" in his painting. Every detail is the outgrowth of the central reality.... "Painting admits not a Grain of Sand or a plade of Grass Insignificant..." (LJ, K 611)."166

Blake's attention to microcosms such as the "Heaven in a Wild Flower"16? is a manifestation of his special kind of visionary imagination; it is capable of transforming the ordinary to the extraordinary, when augmented by the precision conferred by his eidetic imagery. This inclination toward the art of miniaturism recurs in minute detailing such as the fine ruching to Jesus's gown in Christ Blessing (Figure 3 ). This evidences the discriminating eye of the miniaturist, the philosophical impulse of the humanist, and the allegorizing spirit of Gothic iconography.

Blake uses social satire to focus visionary imagination as the means of freedom from the constraints of obsessive order. Sensory gratification is not the aim of this freedom, since $B l a k e$ explains that "the human imagination is to be the source of all perceptions of God and all

166 S. Foster Damon, A Blake Dictionary: The Ideas and Symbolism of William Blake, Rev. ed. (Hanover: University of New England, 1988 ) 319 .

167 William Blake, "Auguries of Innocence," line 2, Blake's Poetry and Designs, Mary Lynn Johnson and John E. Grant, eds. (New York: W.W. Norton \& Company, Inc., 1979 ) 209. 
conceptions of regenerate humanity."168 This is not to say that Blake advocates a total abandonment of parameters; boundaries clearly do exist which need to be unified. Subsequent to his Descriptive Catalogue of 1809, Blake writes about the "bounding line" in art and life which is necessary to distinguish between the "indefinite" and true vision; visionary imagination transforms the individual through direct, personal experience of inner divinity. Blake was clear about the significance of his vision in the Descriptive Catalogue, where he says,

"The great and golden rule of art, as well as of life, is this: That the more distinct, sharp, and wirey the bounding line, the more perfect the work of art... The want of this determinate and bounding form evidences the want of idga in the artist's mind..." (DesC XV,K 585$)$.

This emphasis on the strong demarkation between clarity of vision and diffuseness is also Blake's particular debt to High and Late Gothic; it is also the result of his eidetic imagery and humanistic philosophy, in addition to his methods for dramatization of visionary imagination. The impetus for symbols which coalesce into a 'vision' is primary certitude; the criterion for clarity is infallible

168 Editorial Criticism Prefacing William Blake, "All Religions Are One," Blake's Poetry and Designs, Mary Lynn Johnson and John E. Grant, eds. (New York: W.W. Norton \& Company, Inc., 1979) 12 .

169 S. Foster Damon, A Blake Dictionary: The Ideas and Symbolism of William Blake, Rev. ed. (Hanover: University Press of New England, 1988) 319. 
belief in the veracity of the ideas. This lack of dubiousness typifies Gothic iconography.

The ornamentation typical to Gothic bursts with lively energy. Freedom from winter constraint manifests in the swelling buds of spring, bursting flowers of Summer, and fecund pods of Autumn in polysynchronous stages of vegetation exuberant with organic cyclicity. This is an analog to the human condition in which the state of the organism reflects the inner life-force or spirit. The connection of body (image) and soul (poesy) appears clear to the visionary imagination which banishes ambiguity and amorphousness. Blake achieves this clarity of expression in his plates through his unique blend of vivid eidetic imagery and Gothic iconic style; together, these vividly surrealistic modes illustrate his complex Zoa schema of allegorizing to initiate the unification of body (image) and soul (word) by means of the reciprocal action of dramatized and activated visionary imagination. The iconostasis penetrated veils of incense haze and dim candlelight with lurid colors and distinct forms; Blake accomplishes a similar perceptual awakening by using vivid colors and discrete focal shapes. Since generated and experienced exclusively mentally, eidetic imagery remains uncontaminated by exterior effects; this mind-image privileges laser-focus clarity devoid of distractions or color interference, which elevates it to the surrealistic realm with an iconic impact. 
THE HUMAN FORM AS ICON: "THE DIVINE IMAGE"

Blake created icons of humanism to illustrate that visionary imagination can demystify orthodoxy's concealment of inner divinity. The body of his work is visual; the spirit is idea. As Edward J. Rose observes,

Blake, like [Saint] Paul, understands the body under the form of eternity, that is, the body of Christ, which Blake equates with the imagination and which Paul understood as the collective presenge of the individual members of the divine Body .

The idea of the body as Christ in man is reiterated throughout Blake's plates; since "the Eternal Body of Man is the Imagination," and the body is Christ, by dramatizing visionary imagination, Blake reveals Christ. He makes the visionary process known by dramatizing it with eye and vortex motifs so intensely colored and focussed that they seem surreal, while its products he demonstrates as varieties of the human form because "The Divine Body is the Human Imagination itself $(J 5: 59 ; 24: 23 ; 60: 57 ; 74: 13)$,

190 Edward J. Rose, "Blake's Biblical Consciousness and the Problem of the Interpretation of Text and Design," Bucknell Review: Criticism, History, and Intertextuality, Richard Fleming and Michael Payne, eds., vol. 31, no. 1 (Lewisburg: Bucknell Associated University Presses, 1988) 114 . 
which is Jesus." 171 He satirizes hierarchical elitism with its insistence on the need for an intermediary between man and the divine, which entitled either a functionary of the state or of the church. The "bounding line" exists between body and soul merely because they are different states within the same matrix; like ice and steam or brain and mind, they are experienced differently but are actually complementary. The unifying principle is the flame of visionary imagination. This is true of Blake's analogs to body and soul of plate and poem; his imagistic communication cannot be understood without knowing his linguistic patterning; the two are reciprocal, as image and language are shown to be identical in Adam Naming the Beasts (Figure 2). Blake clearly states in "The Divine Image" that each human contains divinity:

Then every man of every clime, That prays in his distress, Prays to the human form divine Love Mercy Pity Peace. 172

And he plainly displays imagistically this state of inner divinity in his beatific Christ Blessing (Figure 3 ). Christ is central to Blake's presentation of the three stages of inner divinity. Accordingly, his three humanistic icons of

191 S. Foster Damon, A Blake Dictionary: The Ideas and Symbols of William Blake, Rev. ed. (Hanover: University Press of New England, 1988) 104.

172 William Blake, "The Divine Image," stanza 4, Blake's Poetry and Designs, Mary Lynn Johnson and John E. Grant, eds. (New York: W.W. Norton \& Company, Inc., 1979) 30 . 
the forms of Adam, Jesus, and Albion form a sort of triptych, an artistic incarnation, to represent three successive stages of man's development from degenerate to generate and, ultimately, regenerate. Blake's humanism is that of a Romantic's extolling of individuality. He admits no inhibiting fear of hubris, as he equates spiritedness with imagination when he says,

Each individual is sacred: his special Genius is "the Holy Ghost in Man" ( $J 91: 10)$. If he humbles himself, he humbles his God ( $E G \quad c: 39)$. He has his own particular duty to perform in this world. Jesus was sent to "abolish the Jewish imposture" (On Watson, $K 387$ ).

To support this philosophy of inner divinity, Blake conceives of Eden as the imagination. This implies that its graphic portrayal represents an externalization of mind. Since the "Jewish imposture" promulgated the idea of Adam as created from red clay rather than capable of selftranscendence, the Judaeo-Christian Adam cannot become unified psychically as an entire being cognizant of his own esse. In Blake's Eden, therefore, Adam is already in a state of partial fall from unity within the personified England, archetypal man Albion. Blake's fleshly Jesus was begotten by a human father out of wedlock; therefore, Blake emphasizes the possibility of a personal sense of identification with a very human Jesus; but spiritually

173 S. Foster Damon, A Blake Dictionary: The Ideas and Symbols of William Blake, Rev. ed. (Hanover: Universiy Press of New England, 1988) 196. 
"'Jesus was all virtue and acted from impulse, not from rules" (MHH 23)."174 Albion is the "Eternal Man" of The Four Zoas, father of all mankind, who falls and is judged in The Four Zoas then resurrected in Jerusalem. These three faces of man in their successive stages as Adam, Jesus, and Albion as paradigms for the human condition offer a triptych of iconic crystallizations to express Blake's humanism. Together, like the traditional triptych which depicts the biblical epic of Creation, Fall, and Resurrection, they represent the eternal epic quest from separation through initiation to return. As observed, Blake's dramatization of visionary imagination in the tradition of Gothic iconography, as adapted to his system of Zoas, is infused with specialized hues of red and gold, as well as blue, which I shall discuss more fully at this point. As previously observed, his icons are also intensified and particularized by his vivid eidetic imagery, which creates a surreal intensity of image (body) as counterpart to his poesy (soul). His symbolic eye and vortex motifs are supplanted by the portrayal of the human eye. While in actuality paint reflects light and lacks stained glass' ability to transmit light, Blake manipulates paint to create the illusion of translucence; it is essential to paint

174 S. Foster Damon, A Blake Dictionary: The Ideas and Symbols of William Blake, Rev. ed. (Hanover: University Press of New England, 1988) 214 . 
metaphorically to convey an impression of inner divinity, since the human eyes depicted are actually capable of both reflecting and transmitting light. As Adam creates forms through words, Jesus begets imagination through ideas, and Albion resurrects $v i s i o n$ to initiate regeneration.

In Adam Naming the Beasts (Figure 2), painted in 1810, Adam's face is fixating. Only the iconic stance of his upper torso and face has any similarity to the appearance of Satan in Satan in His Original Glory (Figure 7). The major distinction between Adam and Satan is in Blake's portrayal of their eyes. Adam's eyes are vibrantly alive to engage the viewer in a tacit dialectic of spirit to encourage a recognition of inner divinity. Satan's eyes are inpenetrably vapid such as those typical of Byzantine icons which insist on the mediation of the priesthood for interpretation. Blake considers Satan to be equivalent to the subconscious aspect of the mind, potentially energetic. Kathleen Raine undermines Blake's demystification; she continues the sort of mystification which requires the decoding of an arcane seer with her statement that

His externality Blake has conveyed in his masklike appearance, as of a puppet_for such the selfhood is, a mere play upon the the surface of the evermysterious life. Blake uses of the self a Swedenborgian term: it is "a form \& organ of life," upheld only by divine influx (another Swedenborgian term).

175 Kathleen Raine, Blake and Antiquity (Princeton: Princeton University Press, 1977) 91. 
Raine might simply state that Blake derived his concept of inner divinity from Swedenborg and that Satan is like a puppet because he represents an aspect of the ego as puppeteer. Instead, her turbid approach which portrays Iife as "ever-mysterious" is at odds with Blake's humanistic intent; he creates art to make spirit manifest in order to reveal truth, and to make it ubiquitously available through stimulating visionary imagination; by dramatizing it imagistically he reveals spirit observed. He demonstrates this in Adam Naming the Beasts (Figure 2), a plate which is one of a series done for his patron Thomas Butts. Others in the group include Christ Blessing (Figure 3), Eve Naming the Birds, The Virgin and Child in Egypt, and Black Madonna. William Vaughan comments that "They are all painted in tempera, and their technical quality suggests that by 1810 he had begun to master this archaic medium."176

In composition, Adam Naming the Beasts (Figure 2) is reminiscent of the formalism of a Medieval tapestry such as that which Blake knew in the sanctuary at Westminster Abbey. Adam has the frontal and hieratic pose of the focal figure in an icon or a stained glass window. He lacks the parted lips, lambent eyes, and beatitude that give Christ Blessing (Figure 3) an air of spiritual bliss. Adam's physiognomy is remarkably similar to Jaensch's verbal description of that

196 William Vaughan, William Blake (London: John Calmann and Cooper Ltd., 1977) 22 . 
associated with the B-type eidetic disposition like Blake's own. ${ }^{177}$ Adam's resemblance to pictorial images of the young Blake is striking; this is a rearticulation of Jesus as divine imagination, which is therefore central to and resembles all humanity. Mary Lynn Johnson believes that the biblical series reveals

a pattern of loss and recovery.... Humankind loses the divine vision; man and woman fall into estrangement; in the fullness of time, they awaken to a sense of shared identity with the "Divine Humanity," whom they come to recognize as an inward presence.

Blake uses his "Poetic Genius [which] is the true Man"ing to demonstrate the process of recovery of this "divine vision." Because all men potentially share in this "Divine Humanity," he emphasizes their physical similarity (body:plate) as container for common essence or inner divinity (soul:poem). Besides the physical similarity between Blake's portrayals of Adam in Adam Naming the Beasts (Figure 2) and of Christ in Christ Blessing (Figure 3), there is congruence in the symbolism; it resides in the

179 E.R. Jaensch, Eidetic Imagery, 30-1, Education through Art, Sir Herbert Read (London: Faber and Faber, 1958) 80-81.

178 Mary Lynn Johnson, "Human Consciousness and the Divine Image in Blake's Watercolor Designs for the Bible: Genesis through Psalms," The Cast of Consciousness: Concepts of Mind in British and American Romanticism, Beverly Taylor and Robert Bain, eds. (New York: Greenwood Press, 1987) 20.

179 William Blake, "All Religions are One," Blake's Poetry and Designs, Mary Lynn Johnson and John E. Grant, eds. (New York: W.W. Norton \& Company, Inc., 1979) 12. 
"kerygmatic or 'performative' gesture which does what it signifies...[to avoid] the solipsism of pure selfreferentiality by extending incarnation to the community of faithful recipients." 180 The Cherubim in Ezekiel's wheels (Figure 1), Adam in Adam Naming the Beasts (Figure 2), and Christ in Christ Blessing (Figure 3 ) all signify heavenward, each with his raised right hand. This gesture beckons the viewer into recognition of spiritual concerns; that inner divinity is available to all individuals through the transformative power of the visionary imagination:

At each stage of revelation the visionary and the vision reflect one another, according to the strength and maturity of the human imagination and its fapacity to recognize the human face of God. 81

Blake reveals the "human face of God" repeatedly in the body of his plates, since "Man is All Imagination. God is Man \& exists in us \& we in him."182 He demonstrates one of these faces of Man in Adam Naming the Beasts (Figure 2).

180 Nelson Hilton, Review, William Blake and the Language of Adam, Robert N. Essick, Blake: An Illustrated Quarterly, Morris Eaves and Morton D. Paley, eds., vol. 23, no. 3, Fall, 1990 (Rochester: University of Rochester, 1990) 68.

181 Mary Lynn Johnson, "Human Consciousness and the Divine Image in Blake's Watercolor Designs for the Bible: Genesis through Psalms," The Cast of Consciousness: Concepts of the Mind in British and American Romanticism, Beverly Taylor and Robert Bain, eds. (New York: Greemwood Press, 1987) 20.

182 William Blake, "On Berkeley," The Complete Writings of William Blake, Geoffrey Keynes, ed. (London and New York, 1957) 775 , A Blake Dictionary: The Ideas and Symbols of William Blake, Rev. ed. (Hanover: University Press of New England, 1988) 263. 
Blake's combination of modified Gothic iconography, specialized color hues, humanistic philosophy, and eidetic imagery dramatize visionary imagination to unify body (plates) and soul (poesy) by insisting that we read his symbolism in light of his poesy as it accretes piece by piece into the cumulative impact of his iconic plate. Incrementally, I will unravel Blake's symbols piece by piece in these three pivotal icons taking them in sequence. Beginning with Adam Naming the Beasts (Figure 2), I will proceed to Christ Blessing (Figure 3 ); lastly, I will evaluate The Dance of Albion (Figure 4). While emphasizing biblical and Zoa-cosmological iconographic influences, insinuated color significances and eidetic elements, as well as eye and vortex symbolism, I will show how Blake's dramatization of the visionary imagination works.

\section{Adam Naming the Beasts}

In this icon of the Biblical first human (Figure 2), there seems to be a slight thickness around Adam's thyroid area immediately below his Adam's apple; this is where the mythical fruit lodged, symbolically to confound his articulation of ideas, since mentation and speech become impaired in a postlapsarian state. For Blake, the fallen state indicates impairment of the imagination. Adam's skin looks smooth and velvety; his eyes are large and slightly protuberant, with both a penetratingly arresting yet inward, 
intensely abstracted quality, as if reflecting the movement of the soul toward truth. ${ }^{183}$ Their focus initiates a dialectic between Adam and viewer; this is the core of Blake's method: whereas stained glass windows transmit light and painted surfaces reflect it, eyes have the capacity do do either. So, the "altering eye alters all" becomes a double entendre. Not only does mentation change perception, the way a thing is viewed, but the eye's affect, or emotional expression, influences the viewer's response. The deliberate asymmetry to Adam's face, pronounced at the eyelids and arched eyebrows gives a more High Gothic naturalistic look despite the Byzantine stylization of the plate's design. This is repeated in the grace of Adam's left hand, the sinistrare with which he partially conceals the serpent of Error. Both Adam's and the serpent's eyes are eidetically vivid and arresting; they tacitly invite the viewer to look until he sees the unseen. Edward J. Rose seems to believe that this is possible because of a Platonic essence of Beauty independent of the human mind, which, like Descartes's theory of an "innate idea" of God, may be intuited and revealed:

Blake's masters are essentially the platonizing Protestant poets Spenser and Milton and Michelangelo and the Mannerists. Like the Mannerists, beauty for Blake is understood to be

183 Plato, The Phaedrus, A History of Philosophy, VolumeI: Greece and Rome, Frederick Copleston, S.J. (New York: An Image Book, 1985) 214 . 
infused into the mind of man directly from the mind of God and exists in the imagination independent of the sense impressions.... [Thereforg] the artist must make the unsichtbar sichtbar.

Blake does make unseen ideas seen as forms by dramatizing visionary imagination to stimulate insight. In Adam Naming the Beasts (Figure 2), he does this incrementally with symbols, especially those of eyes. The chthonic serpent is elevated to Adam's chest; Adam, man of red (imagination, life-force, passion, instinct) clay, and serpent, symbol of instinctual realms, are juxtaposed against the classical influence of Adam's stylized hair and his right finger pointing heavenward to indicate the ethereal realm. Like the Cherubim in Ezekiel's Wheels (Figure 1), Adam symbolically becomes a caduceus which harmonizes elements of earth and spirit. The serpent is plumed to echo this unifying symbolism between grounding and flight, as emblem for the unification of body and spirit. It has its sensing tongue extended toward Adam's face, but its snout is pointing symbolically to the upstretched right finger of Adam; this emphasizes Adam's performative gesture of literalizing ideation into the forms of animals. This plate most clearly dramatizes the interrelationship between

184 Edward J. Rose, "Blake's Biblical Consciousness and the Problem of the Interpretation of Text and Design," Bucknell Review: Criticism, History, and Intertextuality, Richard Fleming and Michael Payne, eds., vol. 31, no. 1 (Lewisburg: Bucknell Associated University Presses, 1988) 122 . 
imagistic and linguistic modes as figures for body and soul. The name and image named fuse; Adam's apparent silence with closed lips underscores the intellectual nature of this process.

The serpent's plumes and tongue are the color and shape of flame, connotative of the presence of los in the bounded form of Orc; Los is invoked as the poetic genius of visionary imagination activated during Adam's monumental task of naming the animals in one creative act. Adam creates the serpent as symbol of error, an aspect of the fallen human psyche which results in selfishness. The creatures are symbolically brought into existence through concerted, imaginative thought since "All Things Exist in the Human Imagination." 185 This linguistic-imagistic complementarity was common in Hebrew mythology, which equated the invocation, "Let there be light,"186 with the inaugurating of physical light notated by "and there was light." Knowing and naming are one in paradise; linguistic reform, reflecting logic for Milton but implying imaginative regeneration for $\mathrm{Blake}$, is the underlying key to the problems of the fallen. While for Milton in Paradise Lost, according to Stanley S. Fish, "the immediate perception of

185 William Blake, Jerusalem, 69:25, A Blake Dictionary: The Ideas and Symbols of William Blake, S. Foster Damon, Rev. ed. (Hanover: University Press of New England, 988) 195.

186 Genesis 1:3, The Holy Bible, King James Version (London: Eyre and Spottiswoode Limited, n.d.) 1. 
logical relations is the hallmark of prelapsarian thought processes as is the possession of a perfect language" 187 where word and thing are synonymous, for Blake it is visionary imagination which ensues in perfect congruence between idea and image. Lack of spiritual light results in the serpent's material, lustful, selfish eye; it can only reflect exterior light back like a mirror. Inner divinity is transmitted through Adam's spirited, empathetic, selfless eye in the manner of light entering a stained glass window; it simultaneously reflects external 'ordinary' light and transmits spiritual radiance. The creatures are at either side of Adam's head to emphasize that they are being thought into existence in a grand act of creative imagination as Blake reveals in Jerusalem, "All Animals \& Vegetations, the Earth \& Heaven [are] contain'd in the All Glorious Image." 188

Adam's right index finger, the dexter, is extended Heavenward in the stylized pose typical of Gothic icons; it emphasizes the connection between thought, idea, and form as it combines symbolically various methods of communication. The visual linking of vegetative microcosmic seed (acorn : organic seed : semen : legos : gathering together : Jesus's

187 Stanley Fish, Surprised by Sin: The Reader in Paradise Lost (New York: St. Martin's Press, 1967) 127 .

188 William Blake, Jerusalem, 49:13, A Blake Dictionary: The Ideas and Symbols of Willaim Blake, S. Foster Damon, Rev. ed. (Hanover: University Press of New England, 1988) 195. 
parables : soul), human microcosmic head (Adam : mind : ideas : imagination : Word : Jesus : soul), serpent's gaze, and human hand suggests the link between various forms of seeds. The connection is established between words, texts, and imagistic designs. Nelson Hilton expands this symbolism to include the concept of triadic relationships implied in the philosophical as oppsed to the mathematical triangle, since

Seed, head, and thumb-index joint are thus the corners of a triangle or triadic relationship which is itself "the seed of Contemplative Thought" ${ }_{18}$ py which "the Imaginative Image returns.

This type of convoluted iconography is typical of the Medieval tradition, which emphasized visual symbols to reach all echelons of society including the non-literate with illuminated manuscripts, stained glass windows, emblems, and the Poor Man's Bible. Blake was immersed in these imagistic modes of communication as a result of his seven-year apprenticeship to Basire at Westminster Abbey. However, as Kathleen Raine points out:

So strong was the influence upon Blake of the Gothic style that another, and apparently contrary influence, that of the Greek Revival, has tended to be overlooked. But, with that infallible gift of genius for being open to the significant... influences at any moment of time, Blake found himself at its center. In about 1782 Thomas Stothard, an older fellow-engraver, introduced

189 Nelson Hilton, Review, William Blake and the Language of Adam, Robert N. Essick, Blake: An Illustrated Quarterly, Morris Eaves and Morton D. Paley, eds., vol. 23, no. 3, Fall, 1990 (Rochester: University of Rochester, 1990) 68. 
Blake to John Flaxman....Blake came for a time to share his friend's enthusiasm for Greek art.

This classical Greek influence, already observed in the deliberately recursive geometry of Newton (Figure 8), appears in the treatment of Adam's hair in Adam Naming the Beasts (Figure 2). His hair is symmetrically and tightly curled, and his upper body is influenced by the proportions of classical design. The precise definition of the hair both of Adam and of Newton is representative of the outward limits of energy, indicative of the presence of Urizen's constrictive principle of rational logic. This is an aspect of Satan, "author of abstract law and hence of art having the false unity of 'Mathematicall Diagrams." 191 It is false because unimaginative; like Milton's in Paradise Lost, Blake's Satan is a reductionistic materialist.

The oak tree behind Adam's left shoulder in Adam Naming the Beasts (Figure 2) is both an arcane and a Gothic symbol. Sacred to the Druids, the acorn and mistletoe are associated with pagan fertility rites. Raymond Lister indicates that:

the oak leaves [symbolise] his errors. The oak with its Druidic associations, was frequently used by Blake to denote Error...; he was aware of the traditional belief that oak was used for the

190 Kathleen Raine, William Blake (New York: Praeger Publishers, Inc., 1971) 27.

191 David Sten Herrstrom, "Blake's Redemption of God in the Laocoön: Literal Incarnation and the Marriage of Picture and Text," Bucknell Review: Criticism, History, and Intertextuality, Richard Fleming and Michael Payne, eds., vol. 30, no. 1 (Lewisburg: Bucknell Associated University Presses, $1986) 39$. 
cross. ${ }^{192}$

His incorporation of it here is another iconographic device to mimic the use of foreshadowing in the biblical comedy. The ivy vine twining around the oak tree is another Gothic and pagan symbol. Both oak and ivy appeared earlier with the stag, another Medieval symbol for Christ, in Blake's Jacques and the Wounded Stag (1806). Emile Mäle points out that the iconographic significance of certain vegetation is conflated with the Medieval love for exuberant nature in general:

The leaves or flowers were chosen for their beauty, the art of the twelfth century choosing the buds, the art of the thirteenth the leaves. These leaves were simplified but not distorted, for their structure and general appearance were respected, and is is easy to recognise a large number of them.

I have already commented on the fact that the tendency toward thinking in pictures had been integral to Medieval non-literate people's worship based on visual imagery 'triggers'; as mentioned, they were accustomed to the iconography of stained glass, emblems, tapestries, Poor Man's Bible, and icons. Blake had been steeped in the Gothic imagistic devices when he was apprenticed as a young man to Basire to sketch the statuary in Westminster Abbey. Sir Herbert Read points out that

192 Raymond Lister, The Paintings of William Blake, (Cambridge: Cambridge University Press, 1986) 26

193 Emiler Mäle, The Gothic Image (New York: Harper \& Row, 1960) 52 . 
Blake himself recognized his affinity with the unknown artists whose work he had so closely and intimately studied during his two years' work for Basire on the Gothic monumentg, in Westminster Abbey and other old churches.

Blake's painting of Adam Naming the Beasts (Figure 2) is his preeminent embodiment of typically High Gothic naturalistic iconographical motifs. Although Sir Herbert Read disagrees with my estimate of its merits, I suggest that his method of evaluation is different from mine, as may be inferred from his comment which admits the plate's affinities with the Gothic spirit, while denigrating its technique:

There is also a graceful tempera painting of 'Adam Naming the Beasts', technically more ambitious [than Satan Arousing the Rebel Angels], and less successful, than the water-colours [sic], 19 which is very characteristic of the Gothic spirit.

The precision of the leaves and acorns in Adam Naming the Beasts (Figure 2) is similar to the lively, individualized late Medieval representations. As noted, that pagan influences were incorporated into the designs is remarked by Emile Mäle:

I suspect too that ancient pagan superstitions bloomed on the capitals into more than one flower. It can hardly be by accident that one finds in so many churches the large leaf of the arum, for instance.... It had been chosen for its mysterious properties. It is still an emblem of fertility to the peasants of the valley of the Oise, and in former days it was used in incantations and

194 Sir Herbert Read, The Meaning of Art (London: Faber and Faber, 1984) 168 .

195 Sir Herbert Read, The Meaning of Art (London: Faber and Faber, 1984) 173 . 
witchcraft. ${ }^{196}$

Another artful design which emphasizes the interrelationship between body (image) and soul (poesy) in Adam Naming the Beasts (Figure 2) is the shape of the apple or pear which is introduced as latent or incipient, a foreshadowing at this point. It appears as a negative image of sky framed behind the branches of the oak tree. A complementary pair of leaves covers the top two thirds of the conceptualized apple/pear. This is a striking symbolic portrayal of the inchoate idea prior to conceptualization (word:poesy) which then issues in form (image:plate). These leaves are not entirely oak, but seem to contain the shape of the fig or grape vine; the vine, symbolic of Dionysiac abandon, is the biblical emblem for concealment of the genitalia subsequent to the traditional Fall into disunity of Adam and Eve. Adam's left ear lobe is visible to denote his inclination toward materialism and is emblematic of his receptivity to listening to the tacit dialectic between ideas, words, and texts as well as that communion between artist and viewer. The implied shell of his ear is reiterated in the scaling of the serpent, which also recurs in the acorn receptacles, fruits of the tree of Error. The serpent's body is red; this is indicative of Los's insinuated presence as imagination and that of Luvah as life-force, passion; that

196 Emile Mäle, The Gothic Image (New York: Harper \& Row, Publishers, 1972) 54 . 
the instinctual aspect predominates is apparent in the eye motif, for the serpent's eye leers.

In the distance beyond the left side of Adam's head are apparently dead trees; only the skeletons of these trees are present rising from pale grey earth or water. This underscores the biblical postlapsarian motif presaging doom. However, Blake uses it to indicate the already fallen state of Adam as an aspect of unified man, Albion. In Blake's cosmology, Adam came into being as the nineteenth son of Los and Enitharmon. 197 "On the Laocoön plate, Satan and Adam are the two sons of Yod.... Adam is the conscious mind and Satan is the subconscious, the source of Energy."198 In Milton, the mundane shell $\mathbf{s}^{199}$ depict Adam as possessing the largest proportion of Urthona, creative genius, and Satan as predominantly Urizenic, "subtile" reasoning; for this reason, Blake portrays Satan as gold, the color symbolic of intellect. The infernal flames of energy are shown coursing upward through Satan in Blake's drawing of the Mundane Egg

197 S. Foster Damon, A Blake Dictionary, Rev. ed. (Hanover: University Press of New England, 1988) 6.

198 S. Foster Damon, A Blake Dictionary, Rev. ed. (Hanover: University Press of New England, 1988) 5.

199 The Mundane Shell is "the shell of the Mundane Egg [which] is the visible sky.... Like all Nature, it is a projection of Man," S. Foster Damon, A Blake Dictionary: The Ideas and Symbols of William Blake, Rev, ed. (Hanover: University Press of New England, 1988) 288. 
in Milton. ${ }^{200}$ Eden is a fourfold state of creativity, where the four Zoas are in a state of regeneration. As noted, Blake's Adam is already degenerate because he is an aspect of Albion, the originally unified archetypal man, fallen into fragmentation in Jerusalem. Eden is the symbolic state of Higher Innocence which is accessible through the visionary imagination.

Consistent with Bonnie Klomp Stevens and Larry L. Stewart's comments on the symbolic significance of "sunset and death" remarked earlier (page 100, above), the animals behind Adam in Adam Naming the Beasts (Figure 2) move from east to west, symbolically traversing from the direction of the rising sun, representative of life's beginning, to the setting sun, indicative of the end of sensate life. The domestic beasts of cow, sheep, and goat are created first, since they are past Adam's right shoulder. The feral

creatures come next, with the stag in a deliberately awkward posture at the left side of Adam's neck. The stag demarks between the domesticated animals which may be eaten and those which are hunted; the stag's rampant pose suggests the leap of death with its head twisted back; knowing that it is a common Medieval emblem for the suffering Christ, its rack of antlers prefigure the crown of thorns. It recalls Jacques and the wounded Stag, where angular forms of stags

200 S. Foster Damon, A Blake Dictionary: The Ideas ans Symbols of William Blake, Rev. ed. (Hanover: University Press of New England, 1988) 288. 
look on from the mid-distance, as the wounded stag laps from the pool next to Jacques. Besides its association with Christ, it is also a recurrent motif in architecture, especially that of the Tudor era. Symbolically, Blake insinuates the ubiquitous presence of Jesus as inner divinity into the plate through the emlem of the stag, as well as through the level, vibrant gaze of Adam, obviously alive with spirit; the hues of red which enliven all life forms invigorated with blood indicate symbolically Jesus's presence, as he represents the process of imagination; therefore, Adam's imaginative constructs are mediated by Los-Jesus, signified by hues of gold and red. The portrayal of spirit in human form is the imagistic counterpart to its linguistic utterance. As David Sten Herrstrom observes, "By metaphorically 'uttering' the divine name, incarnating imagination in works of art, $\mathrm{Blake}$ exalts the body and destroys the idolatry of 'Mathematical' form."201

The Four Zoas, derivative of the four beasts of Revelation based on the four evangelists anticipated in Ezekiel's vision, parade in Adam Naming the Beasts (Figure 2). Here are the four beasts which manifest doubly in Ezekiel's Wheels (Figure 1); next to the stag at the left

201 David Sten Herrsrom, "Blake's Redemption of God in the Laocoön: Literal Incarnation and the Marriage of Picture and Text," Bucknell Review: Criticism, History, and Intertextuality, Richard Fleming and Michael Payne, eds., vol. 30 , no. 1 (Lewisburg: Bucknell Associated Univerity Presses, 1986) 40. 
side of Adam's neck come the lion, the horse, and the dog with a tiny hare at the heels of the lion. The lion represents St. Mark; the traditional symbols for the other evangelists of eagle, ox, and human are present, excepting the eagle, which Blake equates with genius or imagination. However, the other form of the eagle as an amalgam of the serpent and bird is presented as the plumed serpent. The human face is that of Adam's own. The fallen Luvah as Orc appears both in serpent form and as Adam; these two are thrown into focal position because of their dominant roles in the biblical comedy. But the ox has separated from this evangelical grouping to stand dominantly before the domesticated creatures to Adam's right shoulder. In Blake's iconography, the ox symbolises Tharmas, while the lion represents Urizen as shown in his The Four Zoas. Los, with his eagle head of genius has yet to appear fully, since Blake gives the naming of the birds to Eve. The spacing between the ox to the right and the horse to the left of Adam is appropriate to Blake's admonition that "One Law for the Lion \& Ox is Oppression." 202

The vegetation in Adam Naming the Beasts (Figure 2) is tinged with yellow. This is more pronounced on the pair of oak leaves, symbolic of the Druidic oaks of Natural man and of the Plains of Mamre in biblical iconography, in the sky

202 William Blake, The Marriage of Heaven and Hell, Plate 24, Blake's Poetry and Designs, Mary Lynn Johnson and John E. Grant, eds. (New York: W.W. Norton \& Company, Inc., 1979) 101. 
apple/pear and the top leaf at the tip of the branch at Adam's right side. The juxtaposition of nascence and senescence indicates organic cyclicity and the dynamic tension of opposites which characterize life. Since, as mentioned, in Blake's cosmology, there is a partially fallen state at the creation of Adam, as he is the fallen spectre of Los and Enitharmon, aspects of Albion, Adam's postlapsarianism reflects imagination's impairment. The Garden of Eden as Blake's "primary symbol for the world of imagination" 203 is tainted by the human's impaired faculty of intellect; this is due to his fallen state from original unity within Albion. Having fallen from this unity into a lesser state, Adam symbolises contraction; since his primary quality is imagination, conferred by Urthona in the aspect of Los, his disposition is resistant to such constraint or confinement, for Imagination is "the Divine Humanity" ; 204 yet this genius has been crammed into a sentient being reduced to five senses no longer fully opened. It is Blake's prophetic task to reopen these portals through his dramatization of the visionary imagination. His subjunctive declamation, "If the doors of perception were cleansed every

203 David Sten Herrstrom, "Blake's Transformations of Ezekiel's Cherubim Vision in Jerusalem," Blake: An Illustrated Quarterly, Morris Eaves and Morton D. Paley, eds., vol. 15, no. 2, Fall, 1981 (Berkeley: University of Califrornia, 1981) 65 .

204 William Blake, Jerusalem, 70:19, A Blake Dictionary: The Ideas and Symbols of William Blake, S. Foster Damon, Rev. ed. (Hanover: University Press of New England, 1988) 195. 
thing would appear to man as it is, infinite," 205 becomes fulfilled in Ezekiel's Wheels (Figure 1) and in Glad Day (Figure 4); this cosmological vision is blatantly apparent to the stimulated insight because Blake reveals it by dramatizing it. Joseph Campbell explains the implications of a vision so cosmic in scope that it may be only intuited, and remarks the difficulties inherent in its apprehension so succinctly, that it is worth quoting him at some length. Campbell says, that in order

to grasp the full value of the mythological figures that have come down to us, we must understand that they are not only symptoms of the unconscious (as indeed are all human thoughts and acts) but also controlled and intended statements of certain spiritual principles, which have remained as constant throughout the course of human history as the form and nervous structure of the human physique itself. Briefly formulated, the universal doctrine teaches that all the visible structures of the world--all things and beings--are the effects of a ubiquitous power out of which they rise, which supports and fills them during the period of their manifestation, and back into which they must ultimately dissolve. This is the power known to science as energy, to the Melanesians as mana, to the Sioux Indians as wakonda, the Hindus as shakti, and the Christians as the power of God. Its manifestation in the psyche is termed, by the psychoanalysts, libido. And its manifestation in the cosmos is the structure and the flux of the universe itself. The apprehension of the source of this undifferentiated yet everywhere particularized substratum of being is rendered frustrate by the very organs through which the apprehension must be

205 William Blake, "The Marriage of Heaven and Hell," Plate 14, Blake's Poetry and Designs, Mary Lynn Johnson and John E. Grant, eds. (New York: W.W. Norton \& Company, Inc., $1979) 93$. 
accomplished. 206

It is these "organs" of perception which Blake helps us to cleanse by means of his dramatization of visionary imagination.

As mentioned, Satan's predominant quality is opacity; his primary Zoa is Urizen, the Zoa of stultifying rationality and of the stasis of Aristotelian involuted logic which Blake satirized in The Marriage of Heaven and Hell. To symbolize this contraction, the coils of logic are wrapped around Adam's left arm, reminiscent of the sea serpents' coils in Blake's plate for Laocoön; the left is the symbolic side of materialism. Since the stark trees are amid the blue to the left side of Adam's head, they may be still in the process of generation as visible products of a creative act of imagination. The distant landscape is more amorphous than the middle distance or foreground. It simultaneously conveys the sense that Adam is bringing into existence by mentally categorizing the things to the forefront of his imagination, while the less dominant ideas are gradually suffused with creative genius in a backwardsweeping motion. The deliberate flatness of the picture plane, Iike Medieval bas-relief, emphasizes Adam's creative imagination. The audience is challenged unavoidably to

206 Joseph Campbell, The Hero with a Thousand Faces, Bollingen Series XVII, Third Printing (Princeton: Princeton University Press: 1973) 257-58. 
focus on the central human form as it dramatizes the cyclicity of life, which, as observed, Harold Bloom sees as the balance between the Prolific and the Devourer. The Romantic paradigm of the dual reciprocal processes of creativity and destruction are embodied in Adam Naming the Beasts (Figure 2). New can appear only as old is supplanted. The four Zoas are regenerating in the realm of Eden, because already they have lost their first estate of unity, symbolized by Albion, in this four-fold realm; the new vegetation may appear only in balance with the senescent as it decays, since a plenum cannot accomodate more.

To elaborate on Blake's concept of visionary imagination, it is worth quoting his poesy together with Mark Schorer's interpretation at this point. Blake enumerates three different forms of vision in his second letter to Thomas Butts of November 22, 1802:

Now I a fourfold vision see, And a fourfold vision is given to me; Tis fourfold in my supreme delight, And threefold in soft Beulah's night, And twofold Always. May God us keep From single vision and Newton's sleep! (1. 83-8)

The fourfold vision, which is for Blake "my supreme delight," is "the mystical ecstasy."20? For Blake, Eden represents the fourfold state; "Newton's sleep" is the realm of materialism, that simple sensation which sees "with the eye" rather than "through the eye." Mark S. Schorer

207 S. Foster Damon, A Blake Dictionary, Rev. ed. (Hanover: University Press of New England, 1988) 437. 
provides pertinent insights about Blake's different 'levels' of vision. He says that

To the third order of vision, which resembles hallucination, nature may indeed have been a hindrance. Here an image in the mind is projected in space and observed as if it possessed objective reality.....But when the dead brother, Robert, came to Blake in the night and explained to him the method of illuminated printing that he was to make his own, Blake was not experiencing hallucination. This, the final and most frequent order of vision, was simply an extremely vivid mental impression that had no external representation at all. From this kind of vision most of his poetry and his pictures derive, and it differs from the imagemaking capacity of other poets only in its burden of emotional intensity, in its uncontrolled spontaneity, and in its particular preterngtural content and persistent symbolical quality.

Despite the absence of any specific reference to eidetic imagery, this description of "emotional intensity" and "uncontrolled spontaneity" characterize it as meeting identical criteria in those respects. Although Mark Schorer makes no distinction between visionary imagination, hallucination, and eidetic imagery, he does cite an interesting analogy with Samuel Taylor Coleridge's theory of imagination given in the Biographia Literaria. In referring to Blake's theory of "fourfold vision," Schorer likens "single vision" to "Primary "Imagination" and emphasizes the importance of the influence of feeling on perception. He alludes to the

208 Mark Schorer, William Blake: The Politics of Vision, Rep. (Henry Holt and Company, Inc., 1946. Gloucester: Peter Smith, 1975) 7 . 
Single vision, that "Newton's sleep" which Blake scorned, corresponds to Coleridge's Primary Imagination the perception of the everyday world by the senses as these are conceived in such a psychology as Locke's, of...that inanimate cold world allowed

To the poor loveless ever-anxious crowd. But twofold, threefold, and fourfold vision all pertain to the Secondary Imagination, a function which, unsatisfied by mere sense experience of objective reality feels about it, and in doing so reorganizes it.

Blake does not believe the mind to be a tabula rasa; consistent with Protagoras's "Man is the measure of all things," Blake proselytizes that it is the world which apparently becomes conditioned by perception; that fourfold, superimposed patterning is imagistic. As Mark Schorer suggests, Blake's "ideas came to him as images; and his images...are invariably symbolical." 210 Blake's pictures are amplified restatements of the poems, as body vivified with soul. "This is ut pictura poesis with a vengeance, the sister arts joined at birth... To see was immediately to know."211 This method, iconographic in the Gothic tradition, involves what Erwin Panofsky calls "synthetic intuition"; Blake reteaches his audience how to see, since

209 Mark Schorer, William Blake: The Politics of Vision, Rpt. Henry Holt and Company, 1946. Gloucester: Peter Smith, 1975) 9 .

210 Mark Schorer, William Blake: The Politics of Vision, Rpt. (Henry Holt and Company, 1946. Gloucester: Peter Smith, 1975) 11.

211 Mark Schorer, William Blake: The Politics of Vision, Rpt. (Henry Holt and Company, 1946. Gloucester: Peter Smith, 1975) 11 . 
the casual glance misses allegorical implications.

\section{Christ Blessing}

The 'speaking picture' of Christ Blessing (Figure 3 ) is the most perfect instance of Blake's image of Word as the "Human Form Divine." Jesus represents the central icon in Blake's triptych of Adam, Jesus, and Albion. As poet, Blake becomes the Logos. God's Word, whom Blake casts as Adam in Adam Naming the Beasts (Figure 2), brings the imaginative universe into being through its dramatization in the plates to stimulate the audience's visionary imagination. Christ's sign of benediction also becomes the performative gesture; Jesus's gesture is an invocation of imagination, while Adam's is a signal for imagining forms into existence through the act of naming. The same gesture in Ezekiel's Wheels (Figure 1) is made by the "Cherubim as the original of all truly imaginative art, verbal and graphic" as a "sign of peace above the wheels whirling in flames." 212 As David Sten Herrstrom comments, this is a superlative image of the relation of the prophetic poem to its poet and viewer; Blake "expresses this unity in Ezekiel's Wheels by putting the visage of Christ, who 'rides' at the top of the picture, in

212 David Sten Herrstrom, "Blake's Transformations of Ezekiel's Cherubim Vision in Jerusalem," Blake: An Illustrated Quarterly, Morris Eaves and Morton D. Paley, eds., vol. 15, no. 2, Fall, 1981 (Berkeley: University of California, 1981) $64-65$. 
each of the faces which carry him on the wheels below." 213

This is a rearticulation of Jesus as imagination which

therefore includes all humanity and reestablishes

commonality. This is literalized by the relatively generic appearance of the human forms. These cannot be understood without knowing their significance poetically as expressed in Jerusalem; they are

The Four Living Creatures, Chariots of Humanity Divine Incomprehensible,

In beautiful Paradises expand. These are the four Rivers of Paradise

And the Four Faces of Humanity fronting the Four Cardinal Points of Heaven going forward, forward, irresistible
from Eternity to Eternity.

Blake's meditative technique with his viewer is symbolized by the technique which he imputes to his Zoas, who "conversed together in Visionary forms dramatic." 215

Blake's visionary forms become his logos which can be read in his plates.

Nelson Hilton offers an interesting conjecture

213 David Sten Herrstrom, "Blake's Transformations of Ezekiel's Cherubim Vision in Jerusalem," Blake: An Illustrated Quarterly, Morris Eaves and Morton D. Paley, eds., vol. 15, no. 2, Fall, 1981 (Berkeley: University of California, 1981) 66 .

214 Williagm Blake, Jerusalem: The Emanation of the Giant Albion, Plate 98, 24-27, Blake's Poetry and Designs, Mary Lynn Johnson and John E. Grant, eds. (New York: W.W. Norton \& Company, Inc., 1979) 357 .

215 William Blake, Jerusalem, Plate 98,28 , Blake's Poetry and Designs, Mary Lynn Johnson and John E. Grant, eds. (New York: W.W. Norton \& Company, Inc., 1979) 357. 
regarding an alternate derivation of logos from the Greek lego, indicating that lego means "to pick out, to gather," as seeds were gathered. His strongest support premise is that this provides "an etymology pertinent to Jesus' gloss that 'the seed is the word' (Luke $8: 11$ ). The spore, or sperm, or semen, is logos." 216 Hilton's argument is specious; its implications are sound but do not go far enough. The word as idea is potently seminal in the metaphoric sense; when one recalls that it was in allegory that Jesus customarily expressed, the broader connotation of Logos as perhaps an organizing principle, an Arche, is consistent both with Jesus's tone and with the Greek philosophy to which he was heir. Blake's arche, like Jesus' allegorical method, includes also the visual image. To extend the metaphor of fecundity, if the idea is seminal then the icon must be germane; the poetic idea is infused into the iconic image and together they form an embryo; the body enlivened with soul presents visualized idea as body 'contains' soul. This iconic art iterates Blake's mythos of the unifying imagination expressed harmoniously through the "Human Form Divine," which is articulated linguistically in "The Divine Image" and imagistically in Christ Blessing (Figure 3 ). The formal symmetry of Christ's hair and beard

216 Nelson Hilton, Review, William Blake and the Language of Adam, Robert N. Essick, Blake: An Illustrated Quarterly, Morris Eaves and Morton D. Paley, eds., vol. 23, no. 3, Fall, 1990 (Rochester: University of Rochester, 1990) 67. 
with their center partings, his lambent eyes and relaxed face express a spiritual bliss that Raymond Lister says is almost hypnotic. It is a benevolent version of the Great Pentocrator, the omnipotent Lord of the universe, who sternly looks down from the dome of Eastefp Orthodox churches... and...a vision of the Word. 21

But by humanizing his Christ in the more naturalistic style of High Gothic, Blake displays Christ's divinity as an inner state. The "almost hypnotic" effect of the plate is achieved by the gentle penetration of Jesus's gaze, which invites a silent dialectic with his viewer. Blake stimulates insight until the viewer is quietly encouraged to recognize his own essence. Consistent with this emphasis on individuality, Blake opposes authoritarianism with imagination. Andrew Kaufman indicates that $\mathrm{Blake's}$ insistence on the primacy of imagination is his philosophy of being. Kaufman contends that

Blake's rejection of all forms of enforceable authority and his sense of the limited or dubious value of any response directed against such power are consistent with his 2 jnsistence that "Mental Things are alone Real."

This elevation of the importance of imagination is Platonic in general terms, especially with regard to the movement of

219 Raymond Lister, The Paintings of William Blake (Cambridge: Cambridge University Press, 1986) Plate 50.

218 Andrew Kaufman, "Authority and Vision: William Blake's Use of the Gospels," University of Toronto Quarterly: A Canadian Journal of the Humanities, T.H. Adamowski, ed., vol. 57 (3), Spring, 1988 (Toronto: University of Toronto Press, $1988) 400$. 
the soul commented on elsewhere in the context of Blake's vortex symbolism; but its specific opposition to plato's abstract mathematical Forms is shown in Christ Blessing (Figure 3 ), since "Jesus... is ordinarily identified in Blake's work with imagination or "the human form divine," [but] is slain by the process through which Satan codifies gospel into moral law." 219 The plate must be read in light of Blake's poesy, since "Blake understands the pictorial to be related to the verbal as the Divine Body is related to Jesus." 220 Art represents the form of ideas which must be seen through to the mental or spiritual shapes informing it, themselves "too bright to see."22i

Glad Day or The Dance of Albion

The spiritual shapes "too bright to see" dazzle with their radiance in Glad Day (Figure 4) or The Dance of Albion

219 Andrew Kaufman, "Authority and Vision: William Blake's Use of the Gospels," University of Toronto Quarterly: A Canadian Journal of the Humanities, T.H. Adamkowski, ed., vol. 57 , no. 3, Spring, 1988 (Toronto: University of Toronto Press, 1988) 398 .

220 Edward J. Rose, "Blake's Biblical Consciousness and the Problem of Interpretation of Text and Design," Bucknell Review: Criticism, History, and Intertextuality, Richard Fleming and Michael Payne, eds., vol. 31, no. 1 (Lewisburg: Bucknell Associated University Presses, 1988) 122.

221 Edward J. Rose, "Blake's Biblical Consciousness and the Problem of the Interpretation of Text and Design," Bucknell Review: Criticism, History, and Intertextuality, Richard Fleming and Michael Payne, eds., vol. 31, no. 1 (Lewisburg: Bucknell Associated University Presses, 1988) 122 . 
(circa 1794-96). In this culminating plate of the triptych

I have been considering, Blake dramatizes visionary

imagination with his portrayal of the original, integrated human state in its process of regeneration. The anastatic act irradiates inner light to reveal what is actually an inward transformation. At this moment of Eternal time, Albion becomes associated with Jesus, who is the inner light of Imagination as "the Divine Humanity" 222 of Jerusalem, the spiritual 'land' reborn in England. Blake's Jesus as a personification accompanies Albion in his Jerusalem. To develop an understanding of the significance of Blake's Jesus, it is necessary to read his epic; in order to perceive the poetic spirit (soul) which symbolically informs his plate (body), the relationship between Jesus and Albion needs to be seen. Blake reveals that

Then Jesus appeared standing by Albion as the Good Shepherd

By the lost Sheep that he hath found, \& Albion knew that it

Was the Lord, the Universal Humanity; \& Albion saw his Form

A Man, \& they conversed as Man with Man in Ages of Eternity.

Their conversing "as Man with Man" indicates the ubiquitousness of inner divinity; all integrated men, like

222 William Blake, Jerusalem, $70: 19$, A Blake Dictionary: The Ideas and Symbols of William Blake, S. Foster Damon, Rev. ed. (Hanover: University Press of New England, 1988) 195.

223 William Blake, Jerusalem, The Complete Writings of William Blake, Geoffrey Keynes, ed., 743 A Blake Dictionary: The Ideas and Designs of William Blake, S. Foster Damon, Rev. ed. (Hanover: University Press of New England, 1988) 195. 
the unified Albion, are as Jesus because he represents their imagination; therefore, he is as they imagine. Jesus is the non-spatial, non-temporal eternal imagination, which was expressed as Jehovah in the Hebrew scriptures with the incontrovertible, declamatory statement of essence expressed in "I Am that I Am." That this Blakean revelation occurs in "Ages of Eternity" demonstrates its accessibility through the visionary imagination, which perceives contrary states as the "intellectual strife of contraries" in the moment of illumination; thus comes the clearest revelation of what Blake means by his statement so pivotal that $I$ have cited it twice previously: "Fear and Hope are--Vision!" This visionary capacity reveals its harmony; Blake expresses it throughout his poetry besides the epics, notably in his Laocoön, since it is his fundamental credo: "The Eternal Body of Man is The Imagination, that is, God himself, The Divine body, Jesus: we are his Members."224 The monumentality of this vision is reinforced by the figure of Albion, which Blake uses as a type for humanity. Although universally applicable to all humanity, as Geoffrey Ashe reminds us, Albion is derived from the mythological British giant of Anglo-Saxon folk lore:

224 William Blake, Laocoön, The Complete Writings of William Blake, Geoffrey Keynes, ed. (London and New York, 1957) 776. A Blake Dictionary: The Ideas and Symbols of William Blake, S. Foster Damon, Rev. ed. (Hanover: University Press of New England, 1988) 195. 
William Blake, in his conception of the giant Albion, ranged far beyond accepted legend. By making this island [Britain] the source of the primeval world-order, he was able to present the giant as a symbol of humanity, Primordial Man. Yet he did not turn him into a pure abstraction. He kept in touch with the mythologies he transcended, and, in particular, with a leading figure ing the mythology of Britain [King Arthur]."

But Albion becomes more than an emblem of Britain. Blake expands his allegory to encompass all humanity. Albion personifies the unified original Zoa, or complete being, of The Four Zoas seeking reunification after his judgment in Jerusalem. This is Blake's grandest articulation of his subversion of the Great Chain of Being paradigm; Albion is the personification of microcosmic contained within macrocosmic man, who also perverts hierarchies, since divinity is recognized no longer as supralunary but as inner. He possesses an equilibrium of those qualities subsequently symbolically represented in fragmentation by the four Zoas split into their various respective Emanations and Spectres. Cosmologically, Albion symbolizes the Great Chain of Being; politically, he symbolizes a reunified Britain and might represent applause for the London riots of 1780 , if Jacob Bronowski's supposition is correct; ${ }^{226}$ humanistically, Albion represents the microcosm (unified

225 Geoffrey Ashe, Mythology of the British Isles (North Pomfret, Vermont: Trafalgar Square Publishing, 1990) 291 .

226 Jacob Bronowski, william Blake and the Age of Revolution, (New York: Harper \& Row, 1965) 66. 
aspects of the personality) within the macrocosm (the cosmos); somatically and psychologically as well as theologically, he demonstrates personal individuation in harmony simultaneously with the organic and with the spiritual realms. To cite Geoffrey Ashe once more:

Albion is Britain personified. But he is more, because the poet adopts a theory that Britain was the universal fountain-head of wisdom and culture. All humanity was an extension of Albion, so Albion can represent all humanity. The world fell into degeneracy and strife, which Blake symbolizes as Albion sinking into a deathlike trance. The sleep of [hing] Arthur is an image of this in familiar legend. When Arthur wakes, 'the Sun of Britain shall rise again', ${ }_{22}$ sic] and that corresponds to Albion's...waking.

To emphasize the universality of his allegory, Blake uses specific iconography in his depiction of the giant Albion. Albion is the personification of England not mentioned by Geoffrey of Monmouth but alluded to by Holinshed in his Chronicles of England.

In Glad Day (Figure 4), the figure of Albion stands with his left foot, representative of the senses, firmly placed on the still-being-generated organic matter, signified by its blue tone (Tharmas); his right (spiritual) foot is diagonally placed, at a level higher than the mundane left, amid the still yellow-red fiery zone equated in Blake's iconography with imagination (Los) and with instinctual passion, life-force (Luvah). Albion's arms are

227 Geoffrey Ashe, King Arthur (London: Thames and Hudson Ltd., 1990) 64 . 
extended wide at right angles to his torso, with hands thrown palms outward. His palms are stretched fully as if to indicate the East and the west reaches of creation, with thumbs directed heavenward. His left foot marks exact South, while Albion's head is to the North yet inclined slightly to the East, direction of the dawn. Each cardinal point of the compass implies one of the Zoas, now reintegrated into cosmic man. Rather than a Zoa-headed cosmic Cherubim as in Ezekiel's wheels (Figure 1), the Zoas are internalized within Albion in Glad Day (Figure 4). Albion's gesture indicates psychological openness to correspond with his physical nakedness at the same time that the vast cosmos is tacitly encompassed. S. Foster Damon believes that "He corresponds...to Swedenborg's Grand Mam and the Adam Kadmon of the Kabbalists." 228 Damon observes that Albion's posture demonstrates the way in which man's body is a model of proportion because with arms and legs extended it fits into the perfect geometrical forms, the square and the circle. The Renaissance artists made many attempts to fit the human body into these forms. ...The best known is that of Leonardo.

It is telling that Blake, unlike Leonardo da Vinci, omits the geometric forms usually associated with this cosmic

228 S. Foster Damon, A Blake Dictionary: The Ideas and Symbols of William Blake, Rev. ed. (Hanover: University of New England, 1988) 9 .

229 S. Foster Damon, A Blake Dictionary: The Ideas and Symbols of William Blake, Rev. ed. (Hanover: University Press of New England, 1988) 13. 
posture, for, like the Zoas, these two-dimensional schemata have been internalized and reintegrated into the organic three-dimensional whole of the human form suffused with the active force of spirit; these schemata of triangle and arc, diagramatic for the conic section, he reserved for his satire of mechanistic physics already seen in the recursive triangles, the scrolled-up vortices, and the arc at the material feet of the pragmatic ymathematician-philosopher in Newton (Figure 8). Newton neither emanates nor attracts any divine light, since his visionary imagination has been abrogated by logic.

Very distinct from Newton's geometric head and reminiscent of a Gothic aureole, a natural mandala completly surrounds the organic form of Albion; it extends downward to his mid-shins, where dark blue washes into black off at the bottom right corner of the plate. Albion's mandala or sunburst of radiant energy has a threefold division into the primary colors of red (Los : imagination; Luvah : instinctual passion), yellow (Urizen : rational intellect; Los : spiritual intellect), and blue (Tharmas : organic generation). An undulating golden aura, suggestive of a Gothic aureole, surrounds Albion's intellectual and imaginative area, the head; his firm, round head is covered thickly with slightly unruly red locks of hair like Blake's own; the hairline frames his temples with upright curls; the wanton forelock hangs down onto his forehead above the nose. 
His mouth is ample yet delicate. His right eyebrow has an angular curve at the outer area over the temple, whereas his left eyebrow is perfectly bowed. These idiosyncratic physiognomic features compare with the anonymous monochrome watercolor portrait of Blake from the collection of Robert N. Essick, conveying the impression of an eidetic selfportrait conflated with Blake's idiosyncratic iconography of ecstasy to depict the universality of inner divinity. The color and exuberance of Albion's hair indicates the abundant presence of active imagination, since its reddish cast is symbolic of Los. This is far different from Adam's contrived Urizenic locks depicted in Adam Naming the Beasts (Figure 2). The yellow brilliance, white at its focal points and textured into effects of chiaroscuro with stippling as it extends outward from Albion with dark scuzzes and striations of red, irradiates down onto his limbs and torso. Pure white light, indicative of the hottest heat, bursts forth most densely around his procreative pelvic area. The genitalia are complete, with no hint of the androgyny of satan in Satan in His original Glory (circa 1805) (Figure 7 ).

Albion's legs are muscular in Glad Day (Figure 4), with feet fully developed and firmly placed into reality. The middle toes are markedly longer than the large toe, typical again of classical influence. Albion's eyes are large; they have a similar exophthalmic cast to Blake's own. This 
projection of a personal peculiarity was seen depicted in the more controlled and subtle canvas of Adam Naming the Beasts (Figure 2). This combination of generic with idiosyncratic characteristics expresses Blake's concept of ubiquitous inner divinity recognized through the visionary imagination, which he stimulates by its dramatization. Since Los symbolizes creative imagination, he colors Blake's eidetic imagery to reflect that inner divinity, the christ within; therefore, depicted imagistic products resemble the artist-eidetiker Blake. There is meant to be nothing restrained about Albion. He has not been subjected to the Judaeo-Christian constraints or what Blake interprets as the Aristotelian convoluted logic, in which the four categorical levels have become literal causes, as has Adam in Adam Naming the Beasts (Figure 2) and in Elohim Creating Adam. Albion's facial expression is relaxed, with pink, sensuous lips slightly parted. His confrontational pose is ecstatic, unlike Adam's controlled upper torso and head in Adam Naming the Beasts (Figure 2) or Satan's mask-like face in satan in His Original Glory (Figure 7). Albion's is not a distant, hieratic pose. It is the stance of that relaxed tension innate to a unified, self-possessed creature. He has attunement, harmony, at-one-ment with the cosmos; he personifies regenerate man aware of his indestructible esse. Yet his gaze has a wistful expression of self-surrender, congruent with that acceptance of the flux state of cyclic 
generation-degeneration-regeneration of the dying and resurrecting god-self. Albion incorporates the traits common to epic gods; in this sense, he personifies AdonisDionysus-Christ.

The possible genesis and additional exegesis of The Dance of Albion (Figure 4), provided by Raymond Lister, augments its High Gothic influences, since

The figure may have been based on a diagram in Vincenzo Scamozzi's treatise Idea dell' Architettura Universale (Venice, 1615 ), in which an almost identical figure illustrates the proportions of the human body. It is even more likely that Blake based it on illustrations of a Roman bronze of a dancing faun from Herculaneum in the book De' Bronzi Ercolano (1767-71, author unknown), for on the reverse side of the Victoria and Albert drawing he made a pencil drawing resembliong its back view, which closely resembles what the figure of Albion would look like from behind....Blake [may have] intended...Albion's triumphant attitude [to represent] the dawn of what Blake called the 'fourfold vision', the supreme clarity of true spiritual insight. This is possibly confirmed by two features present only in the second state: a bat-winged moth flying towards the background from between Albion's ankles and a worm close to his left foot. These symbols of darkness are being dismissed by Albion as he achieves mystical ecstasy. But some interpreters have seen the worm as a chrysalis from which the moth has freed itself, signifying new birth.

The dark shape flying toward the background in Glad Dav (Figure 4) looks much like a bat-winged moth or bat, but this connotes the subconscious which emerges into consciousness at the moment of Albion's total awareness.

230 Raymond Lister, The Paintings of William Blake (Cambridge: Cambridge University Press, 1986) Plate 10. 
Ordinarily, the worm by Albion's left foot, connotative of materiality, is symbolic of sexual generation; in Blake's iconography here it represents a conflation of organicity with inner transformation. As the imagination flares with brilliant insight, the entire being is released through spiritual ecstasy into somatic regeneration; this is the transformative flame of visionary imagination which initiates healing energy symbolized by the caduceus; this is Blake's art which, as observed earlier, Northrop Frye contends should be considered as a spiritual discipline. $22:$

The caduceus motif is analogous to the schematic representation of the system of interconnected chakras surmised in Kundalini yoga. Both of these symbolic designs represent the tree of healing energy. In yoga, it signifies the human spine entwined with ida and pingala active lifeforce energies; in the caduceus, it is the serpents of chthonic forces surmounted by the wings of spirit, for "The growth of creative energy is the tree of life."232 It seems inconceivable that Joseph Casmpbell did not have Glad Day (Figure 4) in mind when he wrote that

The spell of the past, the bondage of tradition, was shattered with sure and mighty strokes. The dream-web of myth fell away; the mind opened to full waking consciousness; and modern man emerged from ancient ignorance, like a butterfly from its

231 Northrop Frye, Fearful symmetry: A study of hilliam Blake (Princeton: Princeton University Press, 1973) 431.

232 Northrop Frye, Fearful Symmetry, 197. 
cocoon, or like the sun at dawn from the womb of mother night.

The burst of primary colors behind Albion forms a mandala to illustrate the comprehensive nature of this transformation. His mandala is reminiscent of two sets of butterfly wings set at right angles to each other. This aspect of the plate compares with the multiple wings enshrouding Satan in Satan in His Original Glory (Figure 7).

It also has a similar diagonal demarkation between upper and lower zones in the painting plane. Satan's wings are twofold; one set is feathered, while the other is butterfly gossamer; Albion's implied wings are the pure radiant energy of regenerative matter initiated by visionary imagination.

The traditional symbol for the immortality of the psyche, the butterlfy, has emerged from the cocoon of spiritual darkness into the light of spiritual illumination via the transformation or metamorphosis of self-sacrifice of selfishness, the Satanic "state of Error." The second state of Blake's engraving is inscribed: "Albion rose from where he labour'd at the Mill with Slaves: / Giving himself for the Nations he danc'd the dance of Eternal Death." Blake might have identied personally with Albion's depicted state, since he had been released from apprenticeship with Basire

233 Joseph Campbell, The Hero with a Thousand Faces, Bollingen Series XVII, Third Printing (Princeton: Princeton University Press, 1973) 387. 
in 1780 to pursue his unique vision, rather than needing laboriously to copy engravings and sketch stone monuments, being "enslav'd by another man's [system]." The abstract ideal of liberty for the nations is personified by the spirit of England, Albion, as well as humanity's release from the "dark, Satanic mills" of the Industrial Revolution and legalistic codes of state and church orthodoxy.

Blake's imagistic technique is similar to John Ruskin's linguistic method in his essay, "The Nature of Gothic," which is a paradigm of structuralism based on their mutual love for "living Gothic." Like Blake's Gothic iconographic, architectural, and iconic structure for his plates, the typography and syntactic development of Ruskin's "The Nature of Gothic" emulate the architectural design of a Gothic cathedral with flying buttresses on the exterior and amazing fan vaulting above cavernous expanses on the interior. The form of Ruskin's essay with carefully delineated passages noted by Roman numerals proceeds linearly, like perpendicular Gothic. It expands as the theme develops both horizontally and vertically. Suddenly florid, it opens formalistically with an organic flourish into an upward vortex of embellished space, like the chamber above the apse in a cathedral; this acoustical space is designed to resonate the unseen as implicit womb of spirit. Blake's plates are his Gothic iconic structure; his poesy infuses them with spirit. Eidetic imagery enlivens and personalizes 
each plate to make clear the personal nature of divinity as an inner state common to the human condition yet particularized by individuality. He dramatizes the availability of essence with characteristic eye and vortex motifs, symbolic of visionary imagination and eternal time. Blake accomplishes his revelation not by implying spirit's presence by absence in the opened chasm of the cathedral but by insinuating soul into the opening womb beyond the vortex, with specialized color hues and idiosyncratic iconography. He indicates divinity's ubiquitous availability in his triptych of humanistic icons through mirroring eyes which initiate insight. The tacit imagistic-linguistic dialectic of his iconic human forms unify body and soul with their reflection and transmission of two different values of light to stimulate visionary imagination in the process of its dramatization. 
CONCLUSION

I have demonstrated that Blake's visual image is a vehicle for understanding his poesy in eight color plates; that the plates are particularized by eidetic imagery combined with idiosyncratic use of Gothic iconography to reveal the "Human Form Divine" as body (image) containing spirit (poesy); that body and soul are unified through the visionary imagination; that Blake achieves this visual impact by adopting the stylization and symmetry, yet naturalistic individuality, typical of $\mathrm{High}$ and Late Gothic iconic art to dramatize visionary imagination. My proofs have been provided by extensive textual references and critical citations. I have used inferential evidence to support my claim that Blake insinuates his individuality into the iconic images and creates surreal impact, similar to that in the iconostasis, with his eidetic imagery enhanced with specialized hues of red and gold, as well as blue.

Blake's physical likeness to personae in certain plates, especially to Adam in Adam Naming the Beasts (Figure 2), underscores his participation in the essential divinity of universal humanity. He dramatizes this with the enlivened human eyes of Adam and of Jesus, both radiating 
spirit, while in Ezekiel's wheels (Figure 1), he uses cosmic eyes and vortex motifs symbolically to dramatize visionary imagination. Through his self-expression as prophet, Blake illuminates for his readers (through word) and for his viewers (in image) the ubiquitous availability of divinity. By metaphorizing his central self within its system of Zoas, he illustrates the immanence of spirituality within humanity. Blake allegorizes his philosophy that the attainability of bliss is through a recognition of the inner state of harmony within one's own "Human Form Divine." His credo is spontaneous individuality which expresses joyous esse.

Blake articulates the immanence of transcendence in his Christ Blessing (Figure 3 ), Jesus as the epitome of harmony between body and spirit, imagination personified; in his epic figure of Albion in Glad Day (Figure 4), the personification of harmony in the body politic as simultaneously unified, regenerate man; his Cherubim in Ezekiel's wheels (Figure 1) as emblematic of harmony between chthonic (body) and ethereal (soul) energies; his Adam in Adam Naming the Beasts (Figure 2), like Blake himself, as creator of universes named into existence as extensions or literalizations of thought, while recognizing the potency of that metaphorization of transcendence, perfect congruence between idea and idea named into image. The "way of the mystic and of proper art... is of recognizing through the 
metaphors an epiphany beyond words. "234 This is what Blake's images do, for "without images (whether mental or visual) there is no mythology....it is...the arts which allow...things to stand forth and be seen simply as they are... of the nature of being." 235 Blake's vision of the nature of being is expressed in a mythology which is "an organization of insights ...made known by works of visual art and verbal narrative." 236

Although the eight plates do not demonstrate the modeling aspect ascribed to eidetic imagery, their deliberate lack of any sense of depth perception conveys the typical flatness of Gothic friezes, emblems, tapestries, and icons intended to isolate in order to focus the human form. This absence of three-dimensionality underscores the focal human form imaginatively integrating his four psychic principles here and now. Blake's Albion is his symbol for joyous, spontaneous freedom; his Adam represents a crystallization of essence, genius, vivid incarnation; and his Jesus is his most perfect expression of the immanence of transcendence in the "Human Form Divine." As I have shown, throughout the plates various portrayals of "The Divine

234 Joesph Campbell, The Inner Reaches of Outer Space (New York: Harper \& Row, 1988) 21 .

235 Joseph Campbell, The Inner Reaches of Outer Space (New York: Harper \& Row, 1988) 19.

236 Joseph Campbe11, The Inner Reaches of Outer Space (New York: Harper \& Row, 1986) 20. 
Image" invite the viewer into a dialectic with his own fluctuating states and prompt him to unify his psychic aspects through the transformative power of visionary imagination. Blake reveals the ubiquity of inner divinity with his peculiar combination of vivid eidetic imagery and Gothic intensity to focus on his poetic allegory, which "in aesthetic terms...becomes vision" $23 i$ to reveal the human form as body containing soul regenerated through the transformative power of visionary imagination.

Thematically, Blake's plates as imagistic icons of the human body are counterparts to the Gothic cathedral which embodies a spiritual womb; they distill the linguistic content of his poesy as soul. Stylistically, Blake's plates present lucid images filled with allegorical meaning to penetrate veils of literalism in the tradition of the iconostasis. Together, Blake's image and word transform perception to unify body and soul by stimulating the power of visionary imagination, which transcends oppositions, through its dramatization.

${ }^{239}$ E.J. Rose, "Symbolism and Poetic Theory in Jerusalem," Blake's Poetry and Designs, Mary Lynn Johnson and John E. Grant, eds. (New York: W.W. Norton \& Company, Inc., 1979) 597. 


\section{REFERENCES}

Absher, Tom. Men and the Goddess. Rochester: Park Street Press. 1990.

Ahsen, Akhter, Ph. D., Ed. Journal of Mental Imagery. New York: Brandon House, Inc. 1982.

- - Journal of Mental Imagery. Vol.15, No. 1 \& 2 . New York: Brandon House, Inc. 1991.

- - , Journal of Mental Imagery. Vol. 15, No. 3 \& 4 . New York: Brandon House, Inc. 1991.

- - Mental Imagery Abstracts: Journal of Mental Imagery, 1977-1989. New York: Brandon House, Inc. 1989 .

Ariès, Phillipe. The Hour of Our Death. New York: Vintage Books. 1982 .

Arnheim, Rudolph. Art and Visual Perception. Berkley: University of California Press. 1974.

Ashe, Geoffrey. King Arthur: The Dream of a Golden Age. London: Thames and Hudson Ltd. 1990.

- - Mythology of the British Isles. North Pomfret: Trafalgar Square Publishing. 1990.

Behrendt, Stephen C., Ed. History \& Myth: Essays on English Romantic Literature. Detroit: Wayne University Press. 1990 .

Billigheimer, Rachel V. "Blake's 'Eyes of God': Cycles to Apocalypse and Redemption." Philological Quarterly. Vol. 66, No. 2, Spring, 1987. William Kupersmith, Ed. Iowa City: The University of Iowa. 1987.

Bindman, David. Blake as an Artist. New York: E. P. Dutton. 1977 .

- - , The Complete Graphic Works of William Blake. New York: Thames and Hudson. 1978 .

Blake, William. Blake's Poetry and Designs. Mary Lynn Johnson and John E. Grant, Eds. New York: W.W. Norton \& Company, Inc. 1979. 
Bloom, Harold. Blake's Apocalypse. New York: Doubleday \& Company, Inc. 1963 .

- - , The Visionary Company. New York: Doubleday \& Company, Inc. 1963.

Blunt, Anthony. The Art of William Blake. New York: Columbia University Press. 1959.

Bodkin, Maud. Archetypal Patterns in Poetry. New York: Vintage Books. 1958 .

Bronowski, Jacob. William Blake and the Age of Revolution. New York: Harper \& Row. 1965.

Brook-Hunt, Violet. The Story of Westminster Abbey: Being some Account of that Ancient Foundation, its Builders and those who sleep therein. London: James Nisbett \& Co. 1902 .

Brooks, Cleanth. The Well wrought Urn: Studies in the Structure of Poetry. New York: Harcourt, Brace \& World, Inc. 1947 .

Bush, Douglas. Mythology and the Romantic Tradition in English Poetry. New York: W.W. Norton \& Company, Inc. 1963 .

Cadden, John J. and Patrick R. Brostowin, Eds. Science and Literature. Boston: D.C. Heath and Company. 1964 .

Campbell, Joseph. The Inner Reaches of Outer Space. New York: Harper \& Row. 1986.

- - , The Hero with a Thousand Faces. Bollingen Series XVII. Third Printing. Princeton: Princeton University Press. 1973 .

Carpenter, Edward, Ed. A House of Kings: The Official History of Westminster Abbey. New York: The John Day Company. 1966 .

Chippindale, Christopher. Stonehenge Complete. New York: Cornell University Press. 1983.

Christensen, Bryce J. "The Apple in the Vortex: Newton, Blake, and Descartes," Philosophy and Literature, Ed. Denis Dutton, Oct. 1982, Vol. 6, No. 1 and 2, pps. 147 161. Dearborn: The University of Michigan. 1982 .

Coombes, H., M.A. Literature and Criticism. London: Chatto and Windus. 1956. 
Copleston, Frederick, S.J. A History of Philosophy, Vols.

I, II, III. New York: An Image Book, Doubleday. 1985.

Cox, Stephen D. "Recent Work on Blake." Eighteenth-Century Studies. Max Byrd, Robert Hopkins, Arthur McGuiness, Eds. Vol. 18, No. 3, 1984-85. Northfield: American Society for Eighteenth-Century Studies Press, Inc. 1985 .

Damon, S. Foster. A Blake Dictionary: The Ideas and Symbols of William Blake. Rev. Ed. Hanover: University Press of New England. 1988.

Dillard, Annie. Pilgrimat Tinker Creek. New York: Quality Paperback Book Club. 1974 .

Dusen, wilson van. The Natural Depth in Man. New York: Swedenborg Foundation, Inc. 1972.

Ehrenzweig, Anton. The Hidden Order of Art: A Study in the Psychology of Artistic Imagination. London: Granada Publishing, Paladin. 1970 .

Eliade, Mircea. Myth and Reality. New York: Harper \& Row, Harper Torchbooks. 1963.

- - Shamanism: Archaic Techniques of Ecstasy. Princeton: Princeton University Press, Bollingen Series LXXVI. 1972 .

- - The Myth of the Eternal Return. Princeton: Princeton University Press, Bollingen Series XLVI. 1971 .

- - , The Quest: History and Meaning in Religion. Midway Rpt. Chicago: The University of Chicago Press. 1984.

Emboden, william. Narcotic Plants. New York: Collier Books, Macmillan Publishing Co., Inc. 1979.

Erdman, David V., Ed. The Poetry and Prose of William Blake. Garden City: Doubleday, 1970 .

Erdman, David V. and John E. Grant, Eds. Blake's Visionary Forms Dramatic. Princeton: Princeton University Press. 1970 .

Essick, Robert $N$, and Donald Pearce, Eds. Blake in His Time. Bloomington: Indiana University Press. 1978.

Finke, Ronald A. Principles of Mental Imagerv. Cambridge: The MIT Press. 1989. 
Finn, R. Welldon. Domesday Book: A Guide. London: Phillimore \& Co. Ltd. 1973.

Fish, Stanley Eugene. Surprised by Sin: The Reader in Paradise Lost. New York: St. Martin's Press. 1967.

Fisher, Peter F. The Valley of Vision. Toronto: University of Toronto Press. 1961.

Frye, Northrop. Anatomy of Criticism. New Jersey: Princeton University Press. 1973.

- - Fearful Symmetry: A Study of William Blake. Princeton: Princeton University Press. 1974.

- - , The Great Code. New York: Harcourt Brace Jovanovich. 1982 .

Fulleylove, John, R.I., painter, and Arthur Poyser, commentator. The Tower of London. London: A. \& C. Black. MCMIII.

Gardner, Louise. Art through the Ages. Seventh Ed. New York: Harcourt Brace Jovanovich, Publishers. 1980.

Gombrich, E.H. Art and Illusion. Princeton: Princeton University Press, Bollingen Series XXXV. Fifth Edition. 1984 .

Graves, Robert. The Greek Myths: 1. New York: Penguin Books. 1980 .

Haber, Ralph Norman and Ruth B. Haber. "Eidetic Imagery: I. Frequency." Perceptual and Motor Skills. Southern Universities Press. 1961.

Halifax, Joan, Ph.D. Shamanic Voices. New York: E.P. Dutton. 1979 .

Hammond, N.G.L. and H.H. Scullard, Eds. The Oxford Classical Dictionary. Oxford: The Clarendon Press. 1970 .

Heninger, S.K., Jr. "Speaking Pictures: Sidney's Rapprochement Between Poetry and Painting." Sir Philip Sidney and the Interpretation of Renaissance Culture: The Poet in His Time and in Ours, Gary F. Waller and Michael D. Moore, Eds. London: Croom Helm; Totowa, New Jersey: Barnes and Noble. 1984. 
Herbert, George. "The windows." English Seventeenth-

Century Verse, Louis L. Martz, Ed. Vol. 1. New York:

W.W. Norton \& Company, Inc. 1973.

Herrstrom, David Sten. "Blake's Transformations of

Ezekiel's Cherubim Vision in Jerusalem." Blake: An

Illustrated Quarterly. Morris Eaves and Morton D.

Paley, Eds. Vol. 15, No. 2, Fall, 1981. Berkeley:

University of California. 1981.

- - - "Blake's Redemption of God in the Laocoön: Literal Incarnation and the Marriage of Picture and Text."

Bucknell Review: Criticism, History, and Intertextuality. Richard Fleming and Michael Payne, Eds. Vol. 30, No. 1. Lewisburg: Bucknell Associated University Presses. 1986.

Hilton, Nelson. Review of William Blake and the Language of Adam by Robert $N$. Essick in Blake: An Illustrated Quarterly, Morris Eaves and Morton D. Paley, Eds., Vol. 23, No. 23, Fall, 1990. Rochester: University of Rochester. 1990 .

James 1 Version. The Holy Bible. London: Eyre and Spottiswoode Limited, His Majesty's Printers. n.d.

James, William. The Varieties of Religious Experience. New York: Doubleday \& Company, Inc. 1978.

Johnson, Mary Lynn. "Human Consciousness and the Divine Image in Blake's Watercolor Designs for the Bible:

Genesis Through Psalms." The Cast of Consciousness: Concepts of the Mind in British and American

Romanticism. Beverly Taylor and Robert Bain, Eds. New York: Greenwood Press. 1987.

Jung, Carl G., Ed. Man and his Symbols. New York: Dell Publishing Co., Inc. 1968 .

Kaufman, Andrew. "Authority and Vision: William Blake's Use of the Gospels." University of Toronto Quarterly: A Canadian Journal of the Humanities. T.H. Adamkowski, Ed. Vol. 57, No. 3, Spring, 1988. Toronto: University of Toronto Press. 1988.

Larsen, Stephen, Ph.D. The Mythic Imagination. New York: Bantam Books. 1990 .

Lethbridge, T. C. The Painted Men. London: Andrew Melrose Limited. 1954 . 
Lewalski, Barbara Kiefer. Protestant Poetics and the Seventeenth Century Religious Lyric. Princeton: Princeton University Press. 1979.

Linkin, Harriet Kramer. "Revisioning Blake's Oothoön." Blake: An Ilustrated Quarterly, Morris Eaves and Morton D. Paley, Eds. vol. 23, no. 3, Winter, 1989/90. Rochester: University of Rochester. 1990.

Lister, Raymond. The Paintings of William Blake.

Cambridge: Cambridge University Press. 1986.

Long, Kay and Roger R. Easson, Eds. Blake Studies. Tulsa: Univerity of Tulsa. 1968.

Lovejoy, Arthur 0. The Great Chain of Being. New York: Harper \& Row. 1960 .

Mäle, Emile. The Gothic Image. New York: Harper \& Row, Publishers. 1972 .

Martin, w. Keeble, MA, DSc, FLS. The Concise British Flora in Colour. Second Revised Ed. London: Ebury Press and Michael Joseph. 1969.

Matson, Wallace I. A New History of Philosophy: Ancient and Medieval, Vol. 1. New York: Harcourt Brace Jovanovich, Inc. 1987.

Miller, Dan, Mark Bracher, and Donald Ault, Eds, Critical Paths: Blake and the Age of Method. Durham: Duke University Press. 1987.

Minney, R.J. The Tower of London. Englewood Cliffs, New Jersey: Prentice Hall, Inc. 1970.

Mitchell, W.J.T. Blake's Composite Art: A Study of the Illuminated Poetry. Princeton: Princeton University Press. 1978.

Mortimer, W. Golden, M.D. History of Coca: "The Divine Plant" of the Incas. San Francisco: And/Or Press. Fitz Hugh Library Edition. 1974.

Neumann, Erich. Art and the Creative Unconscious. Princeton: Princeton University Press, Bollingen Series LXI . 1971.

Nurmi, Martin K. "I. Blake's Ideal of Expanded Sense Perception." Blake's Poetry and Designs. Mary Lynn Johnson and John E. Grant, Eds. New York: W.W. Norton \& Company, Inc. 1979. 
Ott, Jonathan. Hallucinogenic Plants of North America. Berkeley: Wingbow Press. 1976.

Ovid. Metamorphoses. Rolfe Humphries, Trans. Bloomington: Indiana University Press. 1961.

Paley, Morton D. William Blake. Oxford: Phaidon Press Limited. 1978.

Panofsky, Erwin. Meaning in the Visual Arts. New York: Doubleday \& Company, Inc. 1955.

- - , Studies in Iconolog. New York: Harper \& Row. 1965 .

Piggott, Stuart. The Druids. New York: Frederick A. Praeger. 1968.

Plato. Phaedrus and Letters VII and VIII. Walter Hamilton, Trans. and Intro. Rpt. New York: Penguin Books, Viking Penguin Inc. 1988.

Quasha, George. "Orc as a Fiery Paradigm." Blake's Visionary Forms Dramatic. David V. Erdman and John E. Grant, Eds. Princeton: Princeton University Press. 1970 .

Raine, Kathleen. Blake and Antiquity. New Jersey:

Princeton University Press. 1977.

_ _, William Blake. New York: Praeger Publishers, Inc. 1971 .

- - , Blake and Tradition. Volume II, Bollingen Series XXXV. Princeton: Princeton University Press. 1968.

Read, Sir Herbert. Education Through Art. London: Faber and Faber. 1958 .

- - , Icon and Idea. New York: Schocken Books. 1972 .

- - The Meaning of Art. London: Faber and Faber. 1984 .

Rix, Donna S. "Milton: Blake's Reading of Second Isaiah." Poetic Prophecy in Western Literature. Jan Wojcik and Raymond-Jean Frontain, Eds. Cranbury, New Jersey: Associated University Presses, Inc. 1984. 
Rose, Edward J. "Blake's Biblical Consciousness and the Problem of the Interpretation of Text and Design."

Bucknell Review: Criticism, History, and Intertextuality. Richard Fleming and Michael Payne, Eds. Vol. 31, No. 1. Lewisburg: Bucknell Associated University Presses. 1988.

Schorer, Mark. William Blake: The Politics of Vision. Rpt. Henry Holt and Company, Inc. 1946. Gloucester: Peter Smith. 1975.

Schultes, Richard Evans and Albert Hofmann, Ph.D. Plants of the Gods: Origins of Hallucinogenic Use. New York:

Alfred van der Marck Editions. 1979.

Singer, June K. The Unholy Bible. New York: Harper \& Row. 1970 .

Smith, William Jay. The Streaks of the Tulip: Selected Criticism. Seymour Lawrence: Delacorte Press. 1972.

Sternberg, Robert J., Ed. The Nature of Creativity. New York: Cambridge University Press. 1988.

Stevens, Bonnie Klomp and Larry L. Stewart. A Guide to Literary Criticism and Research. Second Edition. New York: Harcourt Brace Jovanovich College Publishers. 1987 .

Stevens, Wallace. The Necessary Angel. New York: Vintage Books. 1951 .

- - , Voices and Visions II. The Annenberg / CPB Fourdation. South Carolina Educational Network. The National Endowment for the Humanities and the Annenberg / CPB Foundation. Producer: New York Center for Visual History. 1988 .

Taylor, Clyde R. "Iconographical Themes in Wiliam Blake," Blake Studies, Vol. 1, No. 1, Fall, 1968. Tulsa: University of Tulsa. 1968.

Thompson, William Irwin. The Time Falling Bodies Take To Light. New York: St. Martin's Press. 1981.

Tolley, Michael J. Review of Blake's Tyger: A Christological Interpretation in Blake: An Illustrated Quarterly, Morris Eaves and Morton D. Paley, Eds., Vol. 23, No. 3, Fall, 1991. Rochester: University of Rochester. 1991. 
Valdez, Leander Jerome Julian III. The Pharmacognosy of Salvia Divinorum (Epling and Jativa-M): An Investigation of Ska Maria Pastora. Ann Arbor: The University of Michigan, University Microfilms International, UMI Dissertation Information Service. 1983 .

Vaughan, William. William Blake. London: John Calmann and Cooper Ltd. 1977.

Wittreich, Joseph Anthony. "The Poetry of the Rainbow: Milton and Newton among the Prophets," Poetic Prophecy in Western Literature. Jan Wojcik and Raymond-Jean Frontain, Eds. Cranbury, New Jersey: Associated University Presses, Inc. 1984.

Yeats, W.B. "Among School Children." The Collected Poems of W.B. Yeats. Richard J. Finneran, Ed. New Ed. New York: Collier Books, Macmillan Publishing Company. 1989 .

Youngquist, Paul. Madness and Blake's Mvth. University Park: The Pennsylvania State University Press. 1989. 